2. To: (heceiving organization) PNNL

5. Proj./Prog./Dept./Div.:

EM-50/WT

8. Originator Remarks:

Cesium Removal Test Procedures/Instructions for Review and Comments. This document follows the Test Plan issued under EDT \# 605798

11. Recejver Remarks:

3. From: Coriginating Organization)
SESC/PE
6. Cog. Engr-:
D. W. Hendrickson
the Test Plan issued under

4. Related EDT No.: 605798

7. Purchase Order No.: NA

9. Equip./Component No.: NA

10. System/Bldg./Facitity: $222-\mathrm{S} \& 306 \mathrm{E}$

12. Major Assm. Dwg. No.: NA

13. Permit/Permit Apptication No.: NA

14. Required Response Date: 8 January 1997

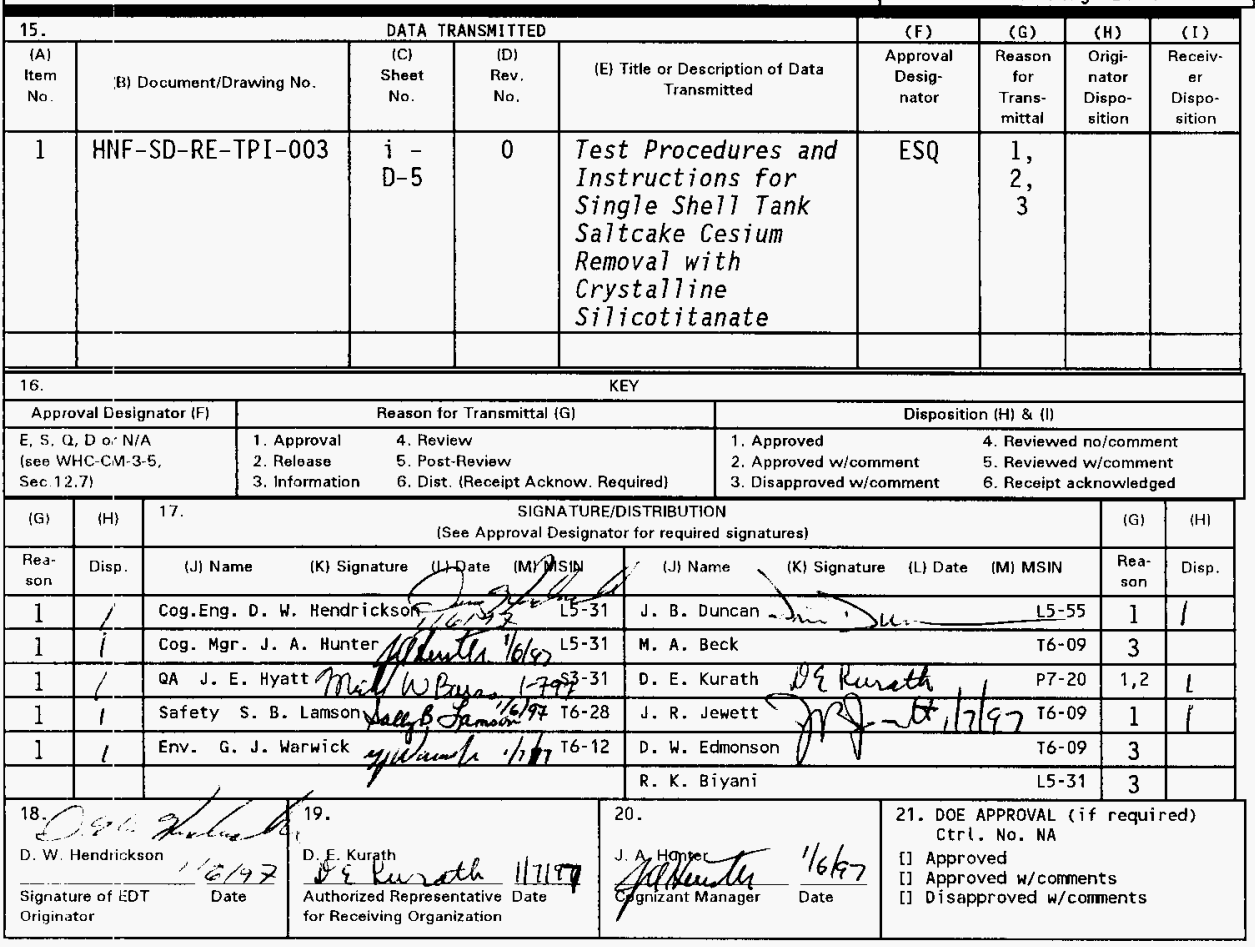

BD-7400-172-2(04/94) GEF097 


\title{
Test Procedures and Instructions for Single Shell Tank Saltcake Cesium Removal with Crystalline Silicotitanate
}

\author{
J. B. Duncan \\ R. K. Biyani \\ D. W. Hendrickson
}

SGN Eurisys Services Corporation, Richland, WA 99352

U.S. Department of Energy Contract DE-ACO6-96RL13200

EDT/ECN: 605785

Org Code: YA400000

B\&R Code: 820201000
UC: 2020

Charge Code: BE1884

Total Pages: 101

Key Words: Hanford, Single Shell Tank, Tank Waste, Saltcake, Cesium, Ion Exchange, Radioactive, IE-911, Crystalline Silicotitanate

Abstract: This document provides specific test procedures and instructions to implement the test plan for the preparation and conduct of a cesium removal test, using Hanford Single Shell Tank Saltcake from tanks 241-BY-110, 241-U-108, 241-U-109, 241-A-101, and 241$\mathrm{S}-102$, in a bench-scale column. The cesium sorbent to be tested is crystalline silicotitanate. The test plan for which this provides instructions is WHC-SD-RE-TP-024, Hanford Single Shell Tank Saltcake Cesium Removal Test Plan.

TRADEMARK DISCLAIMER. Reference herein to any specific commercial product, process, or service by trade name, trademark, manufacturer, or otherwise, does not necessarily constitute or imply its endorsement, recommendation, or favoring by the United States Government or any agency thereof or its contractors or subcontractors.

Printed in the United States of America. To obtain copies of this document, contact: LMSI Document Control Services, P.O. Box 950, Mailstop H6-08, Richland WA 99352, Phone (509) 372-2420; Fax (509) 376-4989.

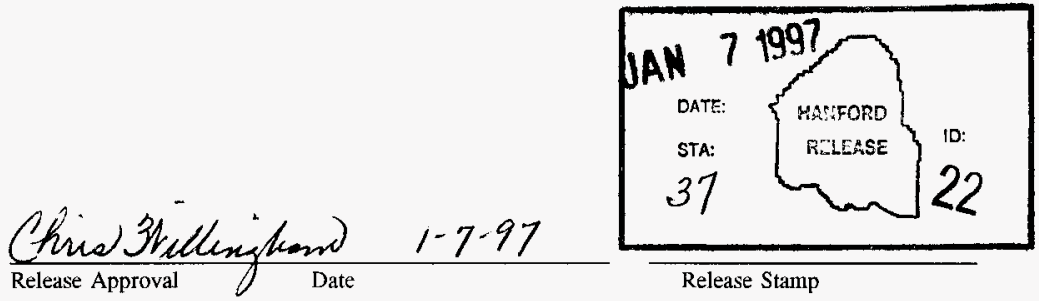

Approved for Public Release 
HNF-SD-RE-TPI-003, Rev. 0

THIS PAGE INTENTIONALLY LEFT BLANK 
1.0 INTRODUCTION

2.0 DESCRIPTION OF TEST $\ldots \ldots \ldots \ldots \ldots \ldots \ldots \ldots \ldots \ldots \ldots$

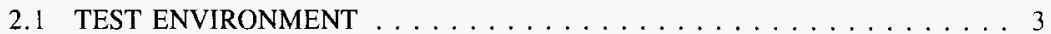

2.2 MATERIAL AND EQUIPMENT NEEDS $\ldots \ldots \ldots \ldots \ldots \ldots \ldots \ldots$

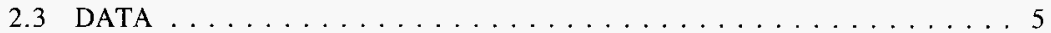

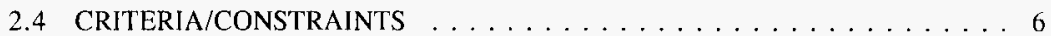

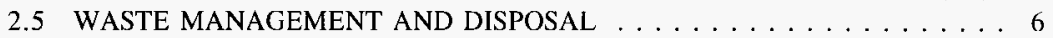

3.0 EXPECTED RESULTS $\ldots \ldots \ldots \ldots \ldots \ldots \ldots \ldots \ldots \ldots$

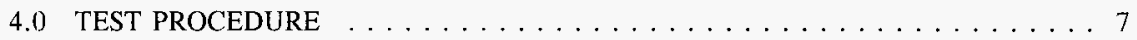

4.1 SYSTEM ACCEPTANCE TESTING AND CALIBRATIONS . . . . . . . 8

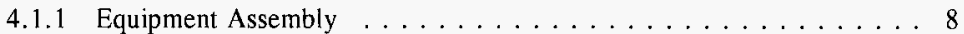

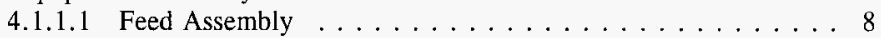

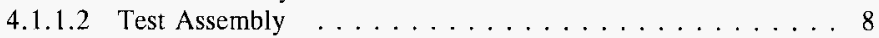

4.1.2 Testing in Cold Environment $\ldots \ldots \ldots \ldots \ldots \ldots$

4.1.2.1 Assembly Leak Test . . . . . . . . . . . . . . 10

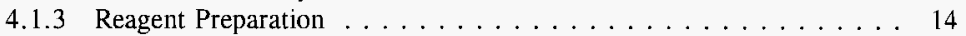

4.1.4 Exchange Material Dissolution $\ldots \ldots \ldots \ldots \ldots \ldots \ldots \ldots$

4.1 .5 Gamma Probe Calibration $\ldots \ldots \ldots \ldots \ldots \ldots \ldots \ldots$

4.2 TEST PREPARATION AND RUN $\ldots \ldots \ldots \ldots \ldots \ldots \ldots \ldots$

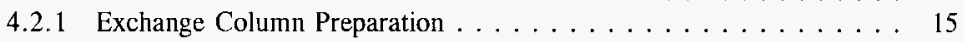

4.2.2 CST Apparatus Pump Curve Acquisition $\ldots \ldots \ldots \ldots \ldots \ldots$

4.2 .3 CST Waste Feed Preparation and Analysis . . . . . . . . 15

4.2 .4 System Flush $\ldots \ldots \ldots \ldots \ldots \ldots \ldots \ldots \ldots$

4.2.5 Cesium Removal Test Run . . . . . . . . . . . . . . 16

4.2.5.1 Gamma Detector Data Logging . . . . . . . . . 17

4.2.5.2 Primary Column Sampling . . . . . . . . . . . 17

4.2.5.3 Secondary Column Sampling . . . . . . . . . . . 17

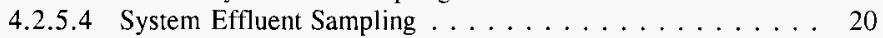

4.2.5.5 Run Execution . . . . . . . . . . . . . . . 20

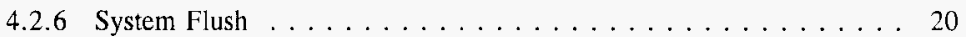

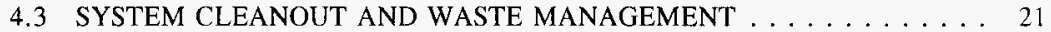

4.3.1 Thermolabile Wastes $\ldots \ldots \ldots \ldots \ldots \ldots \ldots \ldots \ldots \ldots$

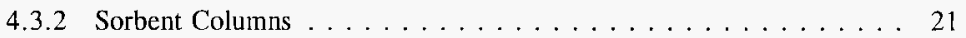

4.3 .3 Other Liquors . . . . . . . . . . . . . . . . . 21

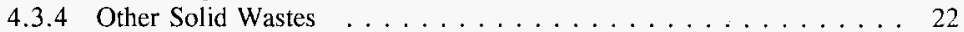

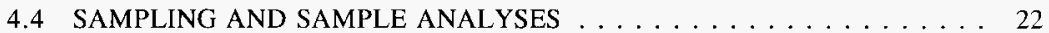


TABLE OF CONTENTS - continued

PAGE

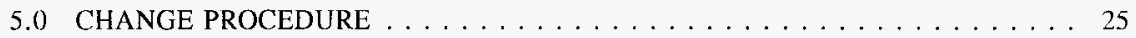

5.1 General Changes . . . . . . . . . . . . . . . . . . . . 25

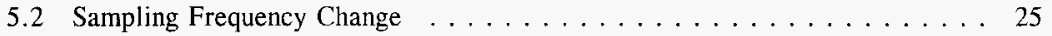

5.3 Pump Flow Rate Reset . . . . . . . . . . . . . . . . . . 25

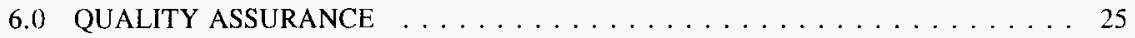

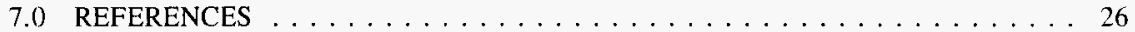

\section{LIST OF APPENDICES}
A: Checksheets and Data Sheets
B: Material Safety Data Sheets
C: Valving Configuration Figures
D: Gamma Probe Operation

\section{LIST OF FIGURES}

PAGE

Figure 1: Bench-Scale Cesium Exchange Flows and Instrumentation . . . . . . . . 2

Figure 2: Physical Test Assembly Valve and Column Arrangement . . . . . . . . . 3

Figure A-1: Bench-Scale Cesium Exchange Flows and Instrumentation . . . . . . . . A-1

Figure A-2: Physical Test Assembly Valve and Column Arrangement . . . . . . . . . A A-2

Figure C-1: Config. 1A, Primary Column (C1a) Full System Feed Valving . . . . . . . C-1

Figure C-2: Config. 1B, Backup Column (C1b) Full System Feed Valving . . . . . . . . C-1

Figure C-3: Config. 2A, Forward Feed through Primary and First Guard Columns . . . C-2

Figure C-4: Config. 2B, Forward Flow Through Backup and First Guard Columns . . . C C-2

Figure C-5: Config. 3A, Forward Flow Through Primary (Cla) Column to Sample . . . C-3

Figure C-6: Config. 3B, Forward Flow Through Backup (C1b) Column to Sample . . . . C C-3

Figure C-7: Config. 4A, Forward Flush Bypass to Line 12A . . . . . . . . . C-4

Figure C-8: Config. 4B, Forward Flush Bypass to Line 12B . . . . . . . . . . . C-4

Figure C-9: Config. 5A, Reverse Flush Through Primary (C1a) Column . . . . . . . . C C-5

Figure C-10: Config. 5B, Reverse Flush Through Backup (C1b) Column . . . . . . C-5

Figure C-11: Config. 6, Reverse Flush Through Guard Columns $(\mathrm{C} 3$ and $\mathrm{C} 2) \ldots \ldots$ C-6 


\section{LIST OF TABLES}

PAGE

Table 1: Reagent Densities at Experimental Temperature . . . . . . . . . . . . 5

Table 2: Saltcake Core and Jar Allocations . . . . . . . . . . . . . . . . 6

Table 3: Valve Connection/Function for CST Columns . . . . . . . . . . . 9

Table 4: CST Test Run Primary Column Sampling ... . . . . . . . . . . . . 19

Table 5: CST Test Run Secondary Column Sampling . . . . . . . . . . . . . . . . 19

Table 6: Cesium Ion Exchange Summary Sample Analysis Plan . . . . . . . . . 22

\section{LIST OF APPARATUS FLOW CONFIGURATIONS}

PAGE

Config. 1: Full System Forward Feed Valving Configuration

(Forward flow to Line 11) . . . . . . . . . . . . . . . . . 11

Config. 2: First Guard Column Forward Feed Valving Configuration

(Forward flow to Line 14) . . . . . . . . . . . . . . 11

Config. 3: Lead Column Forward Feed Valving Configuration

(Forward flow to Line 13) . . . . . . . . . . . . . . . . 12

Config. 4: CST Pump Flow Rate Calibration Valve Contiguration

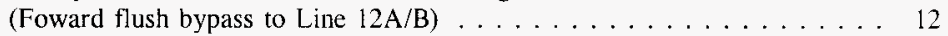

Config. 5: Column Cla/b Reverse Flush Valving Configuration

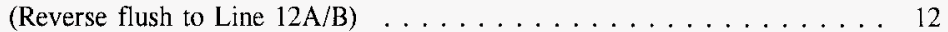

Config. 6: Reverse Feed Valving Configuration

(Reverse flush through guard columns) $\ldots \ldots \ldots \ldots \ldots \ldots \ldots$ 
HNF-SD-RE-TPI-003, Rev. 0

THIS PAGE INTENTIONALLY LEFT BLANK 


\section{Test Procedures and Instructions for Hanford Single Shell Tank Saltcake Cesium Removal with Crystalline Silicotitanate}

\section{0) INTRODUCTION}

Cesium-137 $\left({ }^{137} \mathrm{Cs}\right)$ is a primary radiation source in the dissolved tank waste at the Hanford Site. ${ }^{137} \mathrm{Cs}$ removal from the waste can reduce the hazard and waste classification of the low level waste and reduce treatment and disposal costs.

The object of these test procedures is to conduct a test of cesium sorption of actual Hanford tark waste with materials which have been proposed for development and potential deployment in Hanford Site waste treatment. Treated effluent from these tests is proposed to be received by Battelle Pacific Northwest National Laboratory to conduct technetium sorption studies in further support of site waste treatment needs.

These procedures are written to directly meet the procedural needs of the Hanford Single Shell Tank Saltcake Cesium Removal Test Plan (Duncan et al. 1996) to ensure adequacy of conduct and collection of appropriate samples and data.

This work is funded by the DOE OST Tanks Focus Area under Technology Task Plan RL.37WT42 Cesium Flow Studies at Hanford through Pacific Northwest National Laboratory (PNNL). This task was previously identified under RL07WT42.

\section{1) DESCRIPTION OF TEST}

For this cesium ion exchange test, a test apparatus will be constructed, functionally tested, then placed in a hot cell within the 222-S Laboratory. Approximately five kilograms of saltcake from Hanford Single Shell (SS) Tanks 241-BY-110, 241-U-108, 241-U-109, 241-A-101, and 24]-S 102 will be placed in the hot cell with the test apparatus. The SS saltcake will be solubilized with a dilute caustic solution to a concentration target of $5 \underline{\mathrm{M}}$ sodium and $0.5 \underline{\mathrm{M}}$ hydroxide. The resultant solution will be mixed, settled, decanted, centrifuged or filtered to remove particles, and then placed in feed tank(s) to be used as the feed for the column flow tesis. The tests will be conducted as per the checksheets presented in Appendix A.

The test apparatus will contain a primary test column, a backup test column (in case of fouling) and two scavenging (guard) columns in series to reduce any cesium remaining in the effluent. All columns will be packed with crystalline silicotitanate (CST). The effluent is intended to be provided to subsequent Tanks Focus Area (TFA) tasks which will require the material for 
technetium (Tc) removal studies. A sketch of the process flows and instrumentation is provided

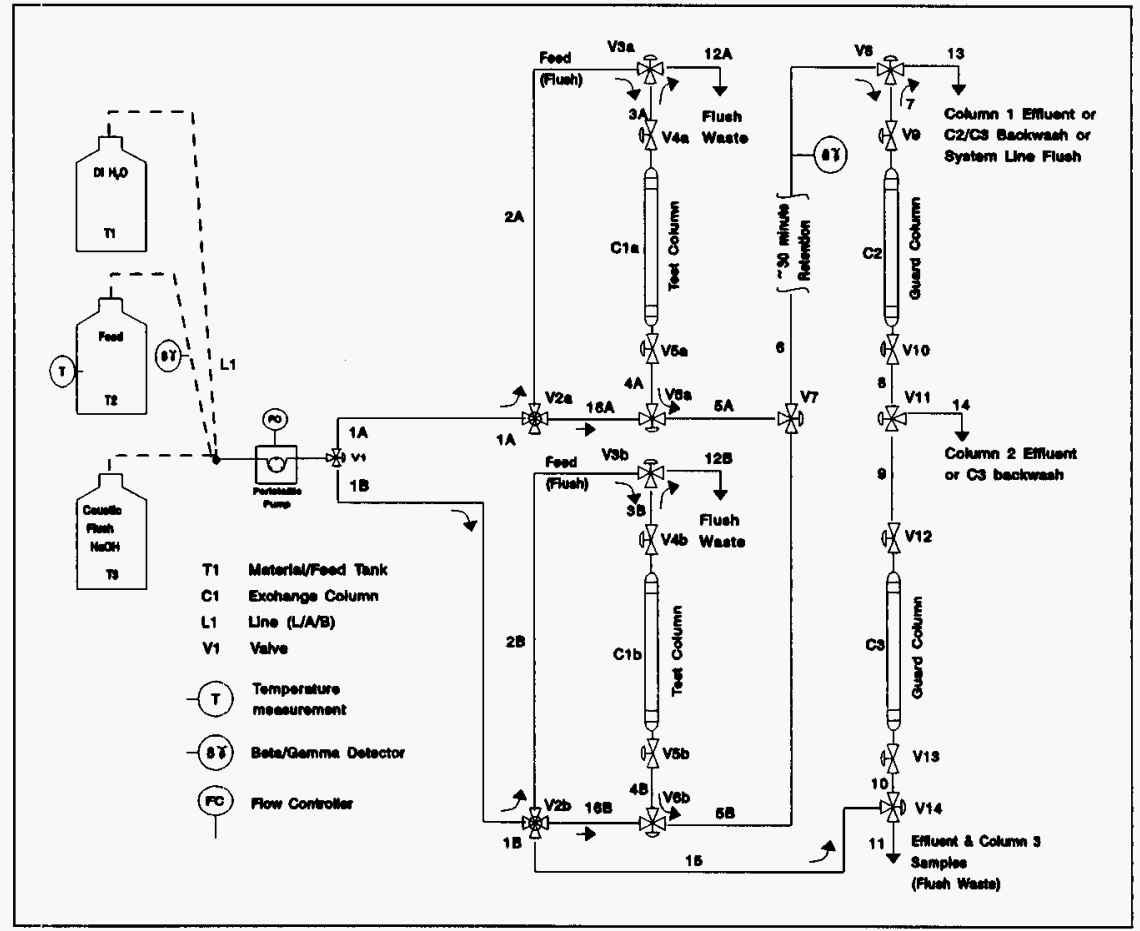

Figure 1: Bench-Scale Cesium Exchange Flows and Instrumentation

in Figure 1. Physical layout of the test apparatus is provided in Figure 2.

During the loading phase of the column test, the feed solution will be pumped from the feed tank downward through a test column of cesium sorbent. The effluent from the test column will be monitored on-line for cesium breakthrough and will be sampled periodically. Samples will also be taken of the feed and guard column effluent, and digested sorbent as necessary. Sample analysis will be performed to determine the concentration of analytes to which the cesium ion exchange and vitrification processes are sensitive. These analytes include: cesium-137, total cesium, strontium, sodium, potassium, rubidium, aluminum, phosphorus (for phosphate), chromium, and iron as well as the $\mathrm{pH}$ of the sample. The feed temperatures will be recorded at the beginning and during the test.

After cesium breakthrough is detected in the test column, it will be flushed and drained, removed from the system, digested, sampled, and disposed. Initial plans for the spent CST are 
in-cell digestion and disposal due to the high sbielding requirements and limited capacity of

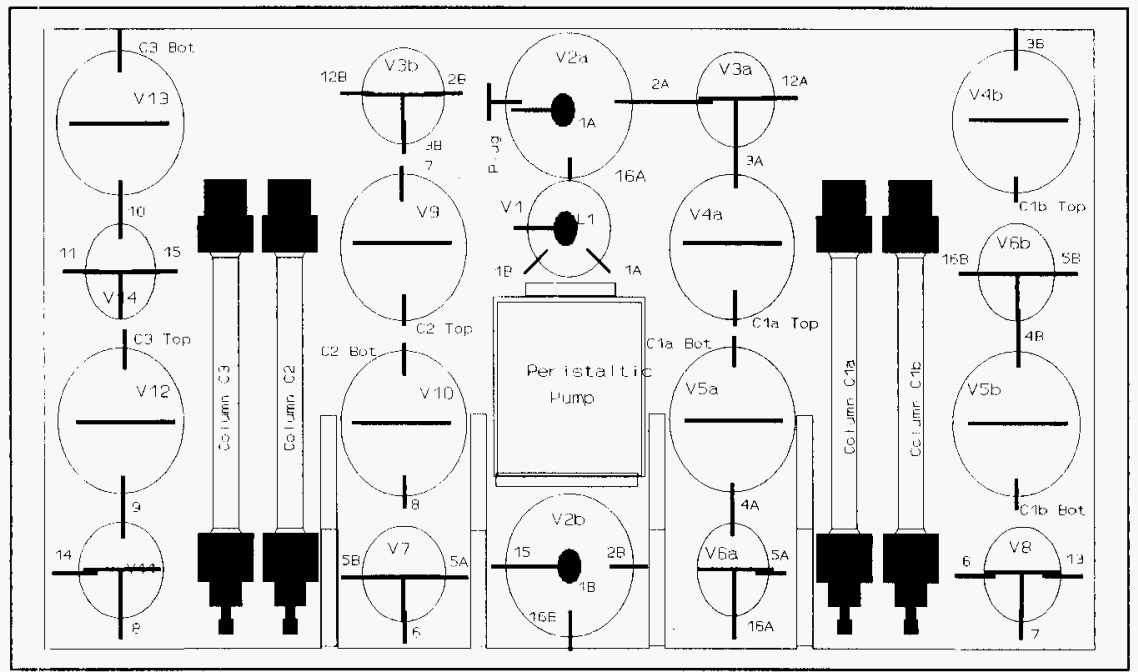

Figure 2: Physical Test Assembly Valve and Column Arrangement

manipulators entailed with removal from the hot cell (Hendrickson and Duncan 1996).

The performance of the sorbents in the removal of cesium from saltcake waste, and process considerations of such removal, will be evaluated and reported in the test report.

\subsection{TEST ENVIRONMENT}

The test environment is primarily that of Hanford's $222-\mathrm{S}$ analytical laboratories.

Assembly of the test equipment is largely anticipated to occur in the 306E laboratories ( 300 Area) followed by acceptance testing in non-radioactive portions of the 222-S laboratories (building 222-SA). The exchange equipment will be placed into a high-radiation hot cell (probably $1 \mathrm{~F}$ ) of the 222-S laboratory where the process tests will occur.

Waste material sample bottles, will be transferred from storage within the 222-S laboratory, to a hot cell for testing.

With the exception of sample analyses at the 222-S laboratory or the Battelle Pacific Northwest National Laboratory 325 laboratory, all tests will be done within a hot cell at 222-S. 


\subsection{MATERIAL AND EQUIPMENT NEEDS}

Equipment needed for the apparatus assembly includes:

2 Exchange Columns, glass, $0.7 \mathrm{~cm}$ internal diameter (ID), packing height $7 \mathrm{~cm}$.

2 Exchange Columns, glass, $1 \mathrm{~cm}$ internal diameter (ID), packing height $10 \mathrm{~cm}$.

8 column clamps for exchange column retention

1 Peristaltic pump, flow range from 7 to $42 \mathrm{~mL} / \mathrm{hr}$

8 gate valves, $-3 \mathrm{~mm} \mathrm{ID}$, Teflon ${ }^{1}$ core

9 T-valves, $\sim 3 \mathrm{~mm}$ ID, Teflon core

2 four way valves, $-3 \mathrm{~mm}$ ID, Teflon core

$5 \mathrm{~m}$ Tygon ${ }^{2}$ tubing, $0.51 \mathrm{~mm}, 0.89 \mathrm{~mm}, 1.59 \mathrm{~mm}, 3.2 \mathrm{~mm}$, and $4.8 \mathrm{~mm}$ ID

1 Waste Feed Tank (T2), polyethylene, $3.8 \mathrm{~L}$

1 Plug, predrilled, for $\mathrm{T} 2,3.8 \mathrm{~cm}$ diameter

$4 \quad$ Waste Feed Bottles, polyethylene, 1L

2 Feed Reagent Tank, polyethylene, $1 \mathrm{~L}$ (caustic, DI $\mathrm{H}_{2} \mathrm{O}$ )

8 Effluent Receivers, polyethylene, $1 \mathrm{~L}$

1 Flush receiver, glass jar, $250 \mathrm{~mL}$

1 Shears for cutting large feed reagent tanks

87 Glass sample vials with polyethylene lined lids, $\sim 20 \mathrm{~mL}$

12 Centrifuge cones, glass, $50 \mathrm{~mL}$

4 sample carriers

1 Continuous $\gamma$ detector and recorder

1 thermometer

1 Runtime clock

1 Sample clock/stop watch

$100 \mathrm{~g}$ CST engineered exchange material (MSDS in Appendix B)

$1 \mathrm{Hot} / \mathrm{stir}$ plate with stir bars

Reagents required (for Material Safety Data Sheets, see Appendix B), and anticipated volumes include:

Deionized Water

Sodium Hydroxide $(\mathrm{NaOH}), 5.0 \underline{\mathrm{M}}$

Hydrofluoric Acid (HF), $1 \underline{\mathrm{M}}$

Hydrochloric Acid $(\mathrm{HCl}), 2 \underline{\mathrm{M}}$

Tank Waste (Table 2)

$\begin{array}{ll}10 & \text { Liters } \\ 2.0 & \text { Liters } \\ 0.125 & \text { Liters } \\ 0.25 & \text { Liters }\end{array}$

0.25 Liters

1 Teflon is a trademark of E. I. duPont de Nemours, Co., Wilmington, DE.

2 Tygon is a trademark of Norton Performance Plastics, Akron, $\mathrm{OH}$. 
T'able 1: Reagent Densities at Experimental Temperature

\begin{tabular}{||l|l|r||}
\hline Reagent & \multicolumn{1}{|c|}{ Molar } & \multicolumn{1}{c|}{$\begin{array}{c}\text { Density } \\
(\mathrm{g} / \mathrm{mL}) 27^{\circ} \mathrm{C}\end{array}$} \\
\hline $\mathrm{HF}$ & 1 & 0.998 \\
\hline $\mathrm{HCl}$ & 2 & 1.031 \\
\hline $\mathrm{H}_{2} \mathrm{O}$ & 55.51 & 0.997 \\
\hline $\mathrm{NaOH}$ & 0.5 & 1.0179 \\
\hline $\mathrm{NaOH}$ & 0.636 & 1.0235 \\
\hline $\mathrm{NaOH}$ & 0.676 & 1.0252 \\
\hline $\mathrm{NaOH}$ & 0.694 & 1.0259 \\
\hline $\mathrm{NaOH}$ & 0.718 & 1.0269 \\
\hline $\mathrm{NaOH}$ & 0.749 & 1.0282 \\
\hline $\mathrm{NaOH}$ & 5.0 & 1.1820 \\
\hline
\end{tabular}

Source: Perry's Chemical Engineer's Handbook, Sixth Edition, R. H. Perry, D. W. Cireen, J. O. Maloney, McGraw-Hill Book Company, New York, New York, 1984.

Facilities required are those of the 222-S laboratory $1 \mathrm{~F}$ hot cell, and nonradioactive portions of 222-S and 306E for equipment assembly and acceptance testing.

Additional or differing equipment and reagents may be applied at the discretion of operating personnel with concurrence of the lead chemist or engineer. Change procedures are provided in $\$ 5.0$. A detail of equipment and reagents used in conduct will be provided in the test report.

\subsection{DATA}

Parameters to be measured, and the precision required is, in large part, defined in the subtask. In general, the parameters of measurement, when not in chemical assay, are those of interval, volume, mass, and gamma decay. In-cell sample masses should be measured to three significant digits, runtimes should be reported in tenths of minutes, sample intervals (by stop watch) should be recorded in tenths of seconds. The subtasks to be described and executed herein are waste feed preparation exchange column packing, activation, flush, operation, sampling, and waste material handling. Chemical assay quality assurance is described by Meznarich (1995). Quality assurance for the conduct of the unit operations and hot cell activities will be in accordance with the approved process testing quality assurance plan (Meznarich 1996). Data Sheets and checksheets for operation are provided in Appendix A. Completed datasheets and checksheets will be entered into appropriate logbooks. 222-S chemical assay analyses will be stored in the laboratory information management system, LabCore. 
Table 2: Saltcake Core and Jar Allocations

\begin{tabular}{|c|c|c|c|c|c|c|c|c|c|c|c|}
\hline \multicolumn{12}{|c|}{ Saltcake Core And Jar Allocations For Feed Material } \\
\hline \multicolumn{2}{|c|}{ Tank 241-U-108 } & \multirow{2}{*}{$\begin{array}{c}\text { Parent } \\
\text { Jar }\end{array}$} & \multirow{2}{*}{\begin{tabular}{|r|}
1,369 \\
$\operatorname{Mass}(\mathrm{g})$ \\
\end{tabular}} & \multirow{2}{*}{\begin{tabular}{|c|} 
Tank \\
Core \\
\end{tabular}} & \multirow{2}{*}{$\begin{array}{r}241-\mathrm{U}-109 \\
\text { Segment }\end{array}$} & \multirow{2}{*}{$\begin{array}{c}\text { Parent } \\
\text { Jar }\end{array}$} & \multirow{2}{*}{\begin{tabular}{r|}
1,722 \\
Mass $(g)$ \\
\end{tabular}} & \multicolumn{2}{|c|}{ Tank 241-A-101 } & \multirow{2}{*}{\begin{tabular}{c|} 
Parent \\
Jar
\end{tabular}} & \multirow{2}{*}{$\begin{array}{r}1,758 \\
\text { Mass(g) }\end{array}$} \\
\hline Core & Segment & & & & & & & Core & Segment & & \\
\hline 146 & $5-\mathrm{U}$ & 10019 & 221.3 & 123 & 4 & 8831 & 195.7 & 156 & 6-U & 11077 & 106.09 \\
\hline 141 & $6-\mathrm{L}$ & 9834 & 156 & 123 & 2 & 8834 & 186.4 & 154 & 7-L & 10566 & 102.2 \\
\hline 146 & $6-\mathrm{U}$ & 10188 & 147.1 & 123 & $7-U$ & 8847 & 140.3 & 154 & $9-\mathrm{L}$ & 11165 & 97 \\
\hline 145 & $7-U$ & 10088 & 139.6 & 123 & 6-U & 8839 & 132.2 & 156 & $7-\mathrm{U}$ & 10611 & 96.36 \\
\hline 141 & $5-\mathrm{L}$ & 9839 & 122.4 & 123 & 6-L & 8840 & 126.8 & 154 & 4-U & 11079 & 92.62 \\
\hline 146 & $6-L$ & 10189 & 121 & 124 & $5-U$ & 8844 & 125.1 & 156 & $3-U$ & 10615 & 91.28 \\
\hline 145 & $8-\mathrm{U}$ & 10018 & 118.2 & 124 & 6-L & 8845 & 121.1 & 154 & $7-U$ & 10572 & 90.6 \\
\hline 146 & $8-U$ & 10092 & 116.1 & 124 & 4 & 8841 & 111.9 & 156 & $4-U$ & 11076 & 90.47 \\
\hline 146 & $7-\mathrm{L}$ & 10182 & 115.8 & 124 & $7-\mathrm{U}$ & 8853 & 109.4 & 156 & $5-\mathrm{L}$ & 10628 & 88.3 \\
\hline 141 & $9-U$ & 10014 & 111.8 & 124 & $6-U$ & 8846 & 100.5 & 154 & $3-U$ & 11068 & 86.7 \\
\hline & & & & 124 & $8-U$ & 8856 & 100.2 & 156 & 4-L & 11078 & 85.09 \\
\hline & & & & 124 & 3 & 8842 & 95.3 & 156 & $8-U$ & 10631 & 83.65 \\
\hline & & & & 124 & $8-\mathrm{L}$ & 8854 & 89.5 & 156 & $3-\mathrm{L}$ & 10620 & 81.45 \\
\hline & & & & 124 & $5-\mathrm{L}$ & 8843 & 87.1 & 154 & 4-L & 11070 & 77.61 \\
\hline & & & & & & & & 154 & 6-L & 11167 & 75.47 \\
\hline & & & & & & & & 154 & $6-\mathrm{U}$ & 11169 & 74.54 \\
\hline & & & & & & & & 154 & 3-L & 10626 & 72.9 \\
\hline & & & & & & & & 156 & $5-U$ & 10612 & 70.3 \\
\hline & & & & & & & & 154 & $2-L$ & 11073 & 66.13 \\
\hline & & & & & & & & 156 & $6-\mathrm{L}$ & 11072 & 65.12 \\
\hline & & & & & & & & 156 & 8-L & 10630 & 64.34 \\
\hline
\end{tabular}

\subsection{CRITERIA/CONSTRAINTS}

Th:is is a treatability test whose activities are governed by WAC 173-303-071(3)(r) [Treatability Study Samples] and WAC 173-303-071(3)(s) [Samples undergoing treatability studies at laboratories and testing facilities] thereby generating a requirement that the Washington State Department of Ecology (WDOE) be notified, in writing, of the intent to conduct treatability studies no less than $\mathbf{4 5}$ days prior to conducting the studies. Treatment of actual waste in the test apparatus shall not proceed unless such a notice compliant with WAC 173-303-071(s)(i) is submitted. (WDOE 1994) As described by the test plan (Duncan et al. 1996), compliance with these provisions has been met with the 1988 notification.

ALARA principles shall guide all actions in this test.

\subsection{WASTE MANAGEMENT AND DISPOSAL}

Wastes from the conduct of this test scope will include spent extraction media, extraction columns, sample bottles, feed bottles (tanks), tygon tubing, valves, waste liquor, treatment eftluent, and sampling wastes. All materials having contacted the tank waste liquor must be 
considered mixed wastes as the tank wastes have been designated to contain F-listed solvents (EPA 1986). To the greatest extent possible, bottles containing wastes brought into the hot cell will be of polyethylene so that they may be melted down within the cell following use. The extraction media will be dissolved, sampled, and poured down the hot cell drain. Excess and spent samples, and undispositioned effluent will be disposed per 222-S laboratory procedures. Glass vessels will be decontaminated and removed from the cell for appropriate waste disposal.

Preliminary dose models (Hendrickson and Duncan 1996) for a similar recent test indicate that shielding sufficient to reduce dose to the $222-\mathrm{S}$ laboratory administrative requirement of $10 \mathrm{mR} / \mathrm{hr}$ would exceed the $18 \mathrm{~kg}(40 \mathrm{lb}$ ) capacity of the cell manipulators. As such, it is not considered safe to remove these materials from the hot cell intact.

\section{1) EXPECTED RESULTS}

This test will demonstrate the cesium selectivity and load capacity of CST using actual Hanford saltcake waste. This information will be compared to similar data gathered using sirnulants and will be used to validate the simulant data's use in designing a cesium removal pretreatment process.

Success of these tests will be in the form of chemical analysis and automatic gamma sample counts demonstrating rise in concentration of the effluent cesium beyond $50 \%$ of inlet concentration (breakthrough, $\lambda_{50}$ ) such that the number of column volumes processed at brisakthrough be determinable on a constant slope.

Guidance from the CST developers indicates that treatment expectation for the CST sorbent is approximately 900 column volumes of saltcake waste feed to $\lambda_{50}$. Due to the uncertainty of this expectation, on-line gamma detection capability will be required to ensure adequate sampling to describe the effluent profile.

\section{1) TEST PROCEDURE}

Th is test procedure is partitioned into three primary subdivisions: system acceptance testing and calibration; CST test run preparation, cesium loading; system flush, necessary decontamination, and waste management. Sampling procedures are a component of each of these subdivisions of the test and are provided as a fourth component of the test.

Laboratory instruction, as necessary will be developed to implement these laboratory 222-S procedures.

Initial pump calibration and sorbent conditioning will be conducted in non-radiological facilities. Thus portions of test through conditioning $(\$ 4.2 .1)$ will be conducted prior to hot cell entry of the assembly. Subsequent work will be conducted in the sequence specified by this document unless modified through change procedure $(\S 5.0)$. All checksheets and data 
sheets are provided in Appendix A.

\subsection{SYSTEM ACCEPTANCE TESTING AND CALIBRATIONS}

The flow system apparatus (apparatus is defined as the entire system to include pumps, valving, plumbing, and columns without the exchange material) will be assembled in the nonradiological 306E laboratories in the 300 Area.

The valving, piping, tubing, columns, and exchange material will be the same that will be used in the hot cell in 222-S laboratory and shall follow the schematic as shown in Figure 1. Physical layout is depicted in Figure 2. The assembly of the apparatus in a cold area will be followed by conditioning and loading of the exchange material in the columns per manufacturer's specifications. With the exception of $\$ 4.1 .5$, acceptance testing and caibration will be nonradiological activities.

\subsubsection{Equipment Assembly}

Ecuipment assembly consists of assembling the tubing, fittings, valves, pump and columns to meet the test needs. Fabrication of the substrate and basin of the test apparatus is conducted separately and prior to this assembly. Checksheets and assembly instructions are provided in Appendix A.

\subsubsection{Feed Assembly}

The ion exchange columns will be loaded and the CST conditioned in preparation for actual waste flow. The conditioning will be accomplished as outlined in section 4.2.1.

The polyethylene feed bottles, for deionized water (T1), waste feed (T2), and $\mathrm{NaOH}$ (caustic flush, T3), will share one line (L1) to the peristaltic pump (Figure 1). The discharge line from the peristaltic pump will connect to a three connection valve (V1). The line diameter selected for the pump mid-range has an ID of $0.51 \mathrm{~mm}$. There will be two lines connected from V1 to the test columns, the $1 \mathrm{~A}$ line to the primary column and the $1 \mathrm{~B}$ line to the backup column. No assembly is required for the feed tanks, thus feed assembly shail consist of assembling line L1 and mounting it through the pump to valve V1. Use Sheet 1 for feed assembly directions, imagery, and checksheet.

\subsubsection{Test Assembly}

The test assembly shall be completed using Sheet 2 . The function of all valve configurations are detailed in Table 3. 
Table 3: Valve Connection/Function for CST Columns

\begin{tabular}{|c|c|c|c|}
\hline Valve & After & Before & Function \\
\hline \multirow{2}{*}{ V1 } & \multirow{2}{*}{$\begin{array}{l}\text { Peristaltic } \\
\text { Pump }\end{array}$} & $\mathrm{V} 2 \mathrm{a}$ & Connects pump to Test bed C1a \\
\hline & & $\mathrm{V} 2 \mathrm{~b}$ & Connects pump to backup Test bed $\mathrm{C} 1 \mathrm{~b}$ \\
\hline \multirow{2}{*}{$\mathrm{V} 2 \mathrm{a}$} & \multirow{2}{*}{$\mathrm{V} 1$} & V3a & Directs Feed to C1a \\
\hline & & V6a & Directs Reverse Flush to Cla \\
\hline \multirow{3}{*}{$\mathrm{V} 3 \mathrm{a}$} & $\mathrm{V} 2 \mathrm{a}$ & $\mathrm{V} 4 \mathrm{a}$ & Directs Feed to $\mathrm{Cla}$ \\
\hline & $\mathrm{V} 2 \mathrm{a}$ & NA & Forward Feed bypass to L12A \\
\hline & $\mathrm{V} 4 \mathrm{a}$ & NA & C1a Reverse Flush flow to receiver \\
\hline \multirow{3}{*}{$\mathrm{V} 2 \mathrm{~b}$} & \multirow{3}{*}{ V1 } & $\mathrm{V} 3 \mathrm{~b}$ & Directs Feed to C1b \\
\hline & & V6b & Directs Reverse Flush to C1b \\
\hline & & V14 & Guard Column Isolation, Reverse Flow \\
\hline \multirow{3}{*}{$\mathrm{V} 3 \mathrm{~b}$} & $\mathrm{~V} 2 \mathrm{~b}$ & V4b & Directs Feed to C1b \\
\hline & $\mathrm{V} 2 \mathrm{~b}$ & NA & Forward Feed bypass to L12B \\
\hline & $\mathrm{V} 4 \mathrm{~b}$ & NA & Clb Reverse Flush flow to receiver \\
\hline \multirow{2}{*}{$\mathrm{V} 4 \mathrm{a}$} & $\mathrm{V} 3 \mathrm{a}$ & Cla & Column Cla isolation, forward \\
\hline & Cla & V3a & Column Cla isolation, reverse \\
\hline \multirow{2}{*}{$\mathrm{V} 4 \mathrm{~b}$} & $\mathrm{~V} 3 \mathrm{~b}$ & Clb & Column Clb isolation, forward \\
\hline & Clb & $\mathrm{V} 3 \mathrm{~b}$ & Column Clb isolation, reverse \\
\hline \multirow{2}{*}{ V5a } & C1a & V6a & Column Isolation, Forward \\
\hline & V6a & Cla & Column Isolation, Reverse \\
\hline \multirow{2}{*}{$\mathrm{V} 5 \mathrm{~b}$} & $\mathrm{Clb}$ & V6b & Column Isolation, Forward \\
\hline & V6b & $\mathrm{C} 1 \mathrm{~b}$ & Column Isolation, Reverse \\
\hline \multirow{2}{*}{ V6a } & V5a & V7 & Directs Flow forward to $\mathrm{V} 7$ \\
\hline & $\mathrm{V} 2 \mathrm{a}$ & V5a & Directs reverse flush to $\mathrm{Cla}$ \\
\hline \multirow{2}{*}{ V6b } & $\mathrm{V} 5 \mathrm{~b}$ & V7 & Directs Flow forward to $\mathrm{V7}$ \\
\hline & $\mathrm{V} 2 \mathrm{~b}$ & $\mathrm{~V} 5 \mathrm{~b}$ & Directs reverse flush to $\mathrm{C} 1 \mathrm{~b}$ \\
\hline \multirow{2}{*}{ V7 } & V6a & V8 & $\begin{array}{l}\text { Forward flow from } \mathrm{C} 1 \mathrm{a} \text { to } 30 \mathrm{~min} \\
\text { retention line }\end{array}$ \\
\hline & V6b & V8 & $\begin{array}{l}\text { Forward flow from } \mathrm{C} 1 \mathrm{~b} \text { to } 30 \mathrm{~min} \\
\text { retention line }\end{array}$ \\
\hline \multirow[b]{2}{*}{ V8 } & V7 & V9 & Directs feed to $\mathrm{C} 2$ \\
\hline & V7 & NA & $\begin{array}{l}\text { Directs } \mathrm{C} 1 \mathrm{a} / \mathrm{b} \text { effluent or } \mathrm{C} 2 / \mathrm{C} 3 \\
\text { backwash or system line flush }\end{array}$ \\
\hline
\end{tabular}


Table 3: Valve Connection/Function for CST Columns

\begin{tabular}{|c|c|c|l|}
\hline Valve & After & Before & \multicolumn{1}{|c|}{ Function } \\
\hline \multirow{2}{*}{ V9 } & V8 & C2 & Column C2 isolation, forward \\
\cline { 2 - 4 } & C2 & V8 & Column C2 isolation, reverse \\
\hline \multirow{2}{*}{ V10 } & C2 & V11 & Column C2 isolation, forward \\
\cline { 2 - 4 } & V11 & C2 & Column C2 isolation, reverse \\
\hline \multirow{2}{*}{ V11 } & V10 & V12 & Forward flow to Column C3 \\
\cline { 2 - 4 } & V10 & NA & Directs C2 effluent to receiver \\
\hline \multirow{2}{*}{ V11 } & V12 & V10 & Directs Flush to C2 \\
\hline \multirow{2}{*}{ V12 } & V11 & C3 & Column C3 Isolation, forward \\
\cline { 2 - 4 } & C3 & V11 & Column C3 Isolation, reverse \\
\hline \multirow{2}{*}{ V13 } & C3 & V14 & Column C3 isolation, forward \\
\cline { 2 - 5 } & V14 & C3 & Column C3 isolation, reverse \\
\hline \multirow{3}{*}{ V14 } & V13 & NA & Column C3 effluent and samples \\
\cline { 2 - 5 } & V2b & V13 & Directs backwash to C3 \\
\cline { 2 - 5 } & V2b & NA & Directs flush waste to receiver \\
\hline
\end{tabular}

$\mathrm{NA}=$ Not Applicable, flow to receiver vessel

The objective of the assembly is to provide feed solutions from the feed lines through the test and guard columns to sample and effluent points.

\subsubsection{Testing in Cold Environment}

Using Figure 1 as a reference for flow streams and Figure 2 as reference for physical layout, the following will be carried out to cold test the system in Building 306E. Care will be taken to try and anticipate problems that may arise during the operation in a hot cell. This will allow a "fix it" mode to be undertaken in a non-radiation area. Figures representing all valving configurations are provided in Appendix $\mathrm{C}$.

\subsubsection{Assembly Leak Test}

The CST will not be loaded in the columns for this portion of the test. All test conduct will be recorded via indicated checksheets and datasheets.

Deionized (DI) water will be pumped through the basic assembly for this phase. The connecting lines are the required ID and length and the valving is connected as indicated in Table 3. Use Sheet 3 and place system into various configurations to check for leaks in full 
forward flow at middle to high set using $\mathrm{Cla}$, and $\mathrm{C} 1 \mathrm{~b}$. Images and valving configurations are provided in Appendix $\mathrm{C}$. The peristaltic pump does not have a digital readout or record. Config. 1: Full System Forward Feed Valving Configuration

(Forward flow to Line 11)

\begin{tabular}{|c|c|c|c||}
\hline \hline Valve & Direction & Valve & Direction \\
\hline \hline $\mathrm{V} 1$ & $\mathrm{~L} 1 \rightarrow \mathrm{V} 1 \rightarrow 1 \mathrm{~A} / \mathrm{B}$ & $\mathrm{V} 8$ & $6 \rightarrow \mathrm{V} 8 \rightarrow 7$ \\
\hline $\mathrm{V} 2 \mathrm{a} / \mathrm{b}$ & $1 \mathrm{~A} / \mathrm{B} \rightarrow \mathrm{V} 2 \mathrm{a} / \mathrm{b} \rightarrow 2 \mathrm{~A} / \mathrm{B}$ & $\mathrm{V} 9$ & $7 \rightarrow \mathrm{V} 9 \rightarrow \mathrm{C} 2$ \\
\hline $\mathrm{V} 3 \mathrm{a} / \mathrm{b}$ & $2 \mathrm{~A} / \mathrm{B} \rightarrow \mathrm{V} 3 \mathrm{a} / \mathrm{b} \rightarrow 3 \mathrm{~A} / \mathrm{B}$ & $\mathrm{V} 10$ & $\mathrm{C} 2 \rightarrow \mathrm{V} 10 \rightarrow 8$ \\
\hline $\mathrm{V} 4 \mathrm{a} / \mathrm{b}$ & $3 \mathrm{~A} / \mathrm{B} \rightarrow \mathrm{V} 4 \mathrm{a} / \mathrm{b} \rightarrow \mathrm{C} 1 / \mathrm{ba}$ & $\mathrm{V} 11$ & $8 \rightarrow \mathrm{V} 11 \rightarrow 9$ \\
\hline $\mathrm{V} 5 \mathrm{a} / \mathrm{b}$ & $\mathrm{C} 1 \mathrm{a} / \mathrm{b} \rightarrow \mathrm{V} 5 \mathrm{a} / \mathrm{b} \rightarrow 4 \mathrm{~A} / \mathrm{B}$ & $\mathrm{V} 12$ & $9 \rightarrow \mathrm{V} 12 \rightarrow \mathrm{C} 3$ \\
\hline $\mathrm{V} 6 \mathrm{a} / \mathrm{b}$ & $4 \mathrm{~A} / \mathrm{B} \rightarrow \mathrm{V} 6 \mathrm{a} / \mathrm{b} \rightarrow 5 \mathrm{~A} / \mathrm{B}$ & $\mathrm{V} 13$ & $\mathrm{C} 3 \rightarrow \mathrm{V} 13 \rightarrow 10$ \\
\hline $\mathrm{V} 7$ & $5 \mathrm{~A} / \mathrm{B} \rightarrow \mathrm{V} 7 \rightarrow 6$ & $\mathrm{~V} 14$ & $10 \rightarrow \mathrm{V} 14 \rightarrow 11$ \\
\hline \hline
\end{tabular}

Config. 2: First Guard Column Forward Feed Valving Configuration

(Forward flow to Line 14)

\begin{tabular}{|c|c|c|c|}
\hline Valve & Direction & Valve & Direction \\
\hline $\mathrm{V} 1$ & $\mathrm{~L} 1 \rightarrow \mathrm{V} 1 \rightarrow 1 \mathrm{~A} / \mathrm{B}$ & $\mathrm{V} 7$ & $5 \mathrm{~A} / \mathrm{B} \rightarrow \mathrm{V} 7 \rightarrow 6$ \\
\hline $\mathrm{V} 2 \mathrm{a} / \mathrm{b}$ & $1 \mathrm{~A} / \mathrm{B} \rightarrow \mathrm{V} 2 \mathrm{a} / \mathrm{b} \rightarrow 2 \mathrm{~A} / \mathrm{B}$ & $\mathrm{V} 8$ & $6 \rightarrow \mathrm{V} 8 \rightarrow 7$ \\
\hline $\mathrm{V} 3 \mathrm{a} / \mathrm{b}$ & $2 \mathrm{~A} / \mathrm{B} \rightarrow \mathrm{V} 3 \mathrm{a} / \mathrm{b} \rightarrow 3 \mathrm{~A} / \mathrm{B}$ & $\mathrm{V} 9$ & $7 \rightarrow \mathrm{V} 9 \rightarrow \mathrm{C} 2$ \\
\hline $\mathrm{V} 4 \mathrm{a} / \mathrm{b}$ & $3 \mathrm{~A} / \mathrm{B} \rightarrow \mathrm{V} 4 \mathrm{a} / \mathrm{b} \rightarrow \mathrm{C} 1 \mathrm{a} / \mathrm{b}$ & $\mathrm{V} 10$ & $\mathrm{C} 2 \rightarrow \mathrm{V} 10 \rightarrow 8$ \\
\hline $\mathrm{V} 5 \mathrm{a} / \mathrm{b}$ & $\mathrm{C} 1 \mathrm{a} / \mathrm{b} \rightarrow \mathrm{V} 5 \mathrm{a} / \mathrm{b} \rightarrow 4 \mathrm{~A} / \mathrm{B}$ & $\mathrm{V} 11$ & $8 \rightarrow \mathrm{V} 11 \rightarrow 14$ \\
\hline $\mathrm{V} 6 \mathrm{a} / \mathrm{b}$ & $4 \mathrm{~A} / \mathrm{B} \rightarrow \mathrm{V} 6 \mathrm{a} / \mathrm{b} \rightarrow 5 \mathrm{~A} / \mathrm{B}$ & \\
\hline \hline
\end{tabular}

Calibration will be conducted with each flow rate change and recorded on Sheet 3. The flow path for calibration will be Config. 1 .

\subsection{Column Forward Tests}

Use Sheet 5 to record and conduct this procedure.

- Tare receiver bottle $(100 \mathrm{~mL}<$ receiver $<250 \mathrm{~mL})$

- Place L1 into feed vessel T1, place line 11 into tared receiver 
- Set valve positions to: Config. 1

Config. 3: Lead Column Forward Feed Valving Configuration

(Forward flow to Line 13)

\begin{tabular}{|c|c|c|c||}
\hline \hline Valve & Direction & Valve & Direction \\
\hline \hline $\mathrm{V} 1$ & $\mathrm{~L} 1 \rightarrow \mathrm{V} 1 \rightarrow 1 \mathrm{~A} / \mathrm{B}$ & $\mathrm{V} 5 \mathrm{a} / \mathrm{b}$ & $\mathrm{C} 1 \mathrm{a} / \mathrm{b} \rightarrow \mathrm{V} 5 \mathrm{a} / \mathrm{b} \rightarrow 4 \mathrm{~A} / \mathrm{B}$ \\
\hline $\mathrm{V} 2 \mathrm{a} / \mathrm{b}$ & $1 \mathrm{~A} / \mathrm{B} \rightarrow \mathrm{V} 2 \mathrm{a} / \mathrm{b} \rightarrow 2 \mathrm{~A} / \mathrm{B}$ & $\mathrm{V} 6 \mathrm{a} / \mathrm{b}$ & $4 \mathrm{~A} / \mathrm{B} \rightarrow \mathrm{V} 6 \mathrm{a} / \mathrm{b} \rightarrow 5 \mathrm{~A} / \mathrm{B}$ \\
\hline $\mathrm{V} 3 \mathrm{a} / \mathrm{b}$ & $2 \mathrm{~A} / \mathrm{B} \rightarrow \mathrm{V} 3 \mathrm{a} / \mathrm{b} \rightarrow 3 \mathrm{~A} / \mathrm{B}$ & $\mathrm{V} 7$ & $5 \mathrm{~A} / \mathrm{B} \rightarrow \mathrm{V} 7 \rightarrow 6$ \\
\hline $\mathrm{V} 4 \mathrm{a} / \mathrm{b}$ & $3 \mathrm{~A} / \mathrm{B} \rightarrow \mathrm{V} 4 \mathrm{a} / \mathrm{b} \rightarrow \mathrm{C} 1 \mathrm{a} / \mathrm{b}$ & $\mathrm{V} 8$ & $6 \rightarrow \mathrm{V} 8 \rightarrow 13$ \\
\hline \hline
\end{tabular}

Config. 4: CST Pump Flow Rate Calibration Valve Configuration

(Foward flush bypass to Line 12A/B)

\begin{tabular}{|c|c|}
\hline Valve & Direction \\
\hline \hline $\mathrm{V} 1$ & $\mathrm{~L} 1 \rightarrow \mathrm{V} 1 \rightarrow 1 \mathrm{~A} / \mathrm{B}$ \\
\hline $\mathrm{V} 2 \mathrm{a} / \mathrm{b}$ & $\mathrm{IA} / \mathrm{B} \rightarrow \mathrm{V} 2 \mathrm{a} / \mathrm{b} \rightarrow 2 \mathrm{~A} / \mathrm{B}$ \\
\hline $\mathrm{V} 3 \mathrm{a} / \mathrm{b}$ & $2 \mathrm{~A} / \mathrm{B} \rightarrow \mathrm{V} 3 \mathrm{a} / \mathrm{b} \rightarrow 12 \mathrm{~A} / \mathrm{B}$ \\
\hline
\end{tabular}

Config. 5: Column C.la/b Reverse Flush Valving Configuration

(Reverse flush to Line 12A/B)

\begin{tabular}{|c|c|c|c||}
\hline \hline Valve & Direction & Valve & Direction \\
\hline \hline $\mathrm{V} 1$ & $\mathrm{~L} 1 \rightarrow \mathrm{V} 1 \rightarrow \mathrm{IA} / \mathrm{B}$ & $\mathrm{V} 5 \mathrm{~A} / \mathrm{B}$ & $4 \mathrm{~A} / \mathrm{B} \rightarrow \mathrm{V} 5 \mathrm{~A} / \mathrm{B} \rightarrow \mathrm{C} 1 \mathrm{~A} / \mathrm{B}$ \\
\hline $\mathrm{V} 2 \mathrm{~A} / \mathrm{B}$ & $1 \mathrm{~A} / \mathrm{B} \rightarrow \mathrm{V} 2 \mathrm{~A} / \mathrm{B} \rightarrow 16 \mathrm{~A} / \mathrm{B}$ & $\mathrm{V} 4 \mathrm{~A} / \mathrm{B}$ & $\mathrm{C} 1 \mathrm{~A} / \mathrm{B} \rightarrow \mathrm{V} 4 \mathrm{~A} / \mathrm{B} \rightarrow 3 \mathrm{~A} / \mathrm{B}$ \\
\hline $\mathrm{V} 6 \mathrm{~A} / \mathrm{B}$ & $16 \mathrm{~A} / \mathrm{B} \rightarrow \mathrm{V} 6 \mathrm{~A} / \mathrm{B} \rightarrow 4 \mathrm{~A} / \mathrm{B}$ & $\mathrm{V} 3 \mathrm{~A} / \mathrm{B}$ & $3 \mathrm{~A} / \mathrm{B} \rightarrow \mathrm{V} 3 \mathrm{~A} / \mathrm{B} \rightarrow 12 \mathrm{~A} / \mathrm{B}$ \\
\hline \hline
\end{tabular}

- After ensuring the flow path is correct to the above valve settings, turn on the peristaltic pump. For this test, $6 \mathrm{CV} / \mathrm{hr}$ are targeted which is approximately $0.27 \mathrm{~mL} / \mathrm{min}$ or $16.1 \mathrm{~mL} / \mathrm{hr}$. Run in this configuration for 3 hours.

- If leaks are observed, adjust fittings as necessary to eliminate leaks. Record observations and leak repairs.

- After the appropriate time period for leak testing in a forward flow mode, shut down the pump. Record masses collected and time interval on Sheet 3. 
Config. 6: Reverse Feed Valving Configuration

(Reverse flush through guard columns)

\begin{tabular}{|c|c|c|c|}
\hline Valve & Direction & Valve & Direction \\
\hline $\mathrm{V} 1$ & $\mathrm{~L} 1 \rightarrow \mathrm{V} 1 \rightarrow \mathrm{IB}$ & $\mathrm{V} 11$ & $9 \rightarrow \mathrm{V} 11 \rightarrow 8$ \\
\hline $\mathrm{V} 2 \mathrm{~b}$ & $1 \mathrm{~B} \rightarrow \mathrm{V} 2 \mathrm{~b} \rightarrow 15$ & $\mathrm{~V} 10$ & $8 \rightarrow \mathrm{V} 10 \rightarrow \mathrm{C} 2$ \\
\hline $\mathrm{V} 14$ & $15 \rightarrow \mathrm{V} 14 \rightarrow 10$ & $\mathrm{~V} 9$ & $\mathrm{C} 2 \rightarrow \mathrm{V} 9 \rightarrow 7$ \\
\hline $\mathrm{V} 13$ & $10 \rightarrow \mathrm{V} 13 \rightarrow \mathrm{C} 3$ & $\mathrm{~V} 8$ & $7 \rightarrow \mathrm{V} 8 \rightarrow 13$ \\
\hline $\mathrm{V} 12$ & $\mathrm{C} 3 \rightarrow \mathrm{V} 12 \rightarrow 9$ & & \\
\hline
\end{tabular}

\subsection{Column Reverse Flow Tests}

\subsection{Column Cla/C1b Reverse Flow Leak}

Use Sheet 11 to record and conduct this procedure.

- Tare receiver bottle $(\sim 100 \mathrm{~mL})$

- Place line L1 in feed vessel T1, place line $12 \mathrm{~A}$ into tared receiver

- Set valve positions to: Config. 5

- After ensuring the flow path is correct to the above valve settings, turn on the peristaltic pump. For this test, $6 \mathrm{CV} / \mathrm{hr}$ are targeted which is approximately $0.27 \mathrm{~mL} / \mathrm{min}$ or $16.1 \mathrm{~mL} / \mathrm{hr}$. Run in this configuration for 1 hour.

- If leaks are observed, adjust fittings as necessary to eliminate leaks. Record observations and leak repairs.

- After the appropriate time period for leak testing in a reverse flow mode, shut down the pump. Record masses collected and time interval on Sheet 11.

\subsection{Columns C2/C3 Reverse Flush Leak}

Use Sheet 12 to record and conduct this procedure.

- Tare receiver bottle $(\sim 100 \mathrm{~mL})$

- Place line L1 into feed vessel T1, place line 12B into tared receiver

- Set valve positions to: Config. 6

- After ensuring the flow path is correct to the above valve settings, turn on the peristaltic pump. For the CST exchanger, $6 \mathrm{CV} / \mathrm{hr}$ are targeted which is approximately $0.27 \mathrm{~mL} / \mathrm{min}$ or $16.1 \mathrm{~mL} / \mathrm{hr}$. Run in this configuration for 1 hour.

- If leaks are observed, adjust fittings as necessary to eliminate leaks. Record observations and leak repairs.

- After the appropriate time period for leak testing in a reverse flow mode, shut down 
the pump. Record masses recovered and time interval on Sheet 12 .

\subsubsection{Reagent Preparation}

The following reagents shall be prepared by the standards laboratory and delivered to 222-S for hot cell entry as needed:

$\begin{array}{lll}\mathrm{NaOH}, \text { aq. } & 5.0 \mathrm{M} & 2.0 \mathrm{~L} \\ \mathrm{HF}, \text { aq. } & 1.0 \underline{\mathrm{M}} & 125 \mathrm{~mL} \\ \mathrm{HCl}, \text { aq. } & 2.0 \underline{\mathrm{M}} & 250 \mathrm{~mL}\end{array}$

Specifications and contaminants of the reagents shall be identified for inclusion in test data analysis.

\subsubsection{Exchange Material Dissolution}

A qualitative evaluation of the dissolution of CST has been carried out in the conduct of test work reported in Hendrickson et al. 1996. It was found that the CST material substrate and binder dissolved satisfactorily with the addition of hydrochloric and hydrofluoric acids. This dissolution will be repeated in this work. Following contact of wastes with the sorbent, the material will be dissolved within the hot cell using Sheet 13.

\subsubsection{Gamma Probe Calibration}

The calibration of the gamma probe will be carried out using 222-S laboratory sources, for a range of $7.4 \mathrm{E} 9 \mathrm{~Bq} / \mathrm{L}$ to $7.4 \mathrm{E} 8 \mathrm{~Bq} / \mathrm{L}\left(0.2 \mathrm{Ci} / \mathrm{L}{ }^{137} \mathrm{Cs}\right.$ to $\left.0.020 \mathrm{Ci} / \mathrm{L}\right)$. The source configuration will be Tygon tubing, $4.76 \mathrm{~mm} \mathrm{ID,} 9.52 \mathrm{~mm}$ OD. The tubing standard should be about $10 \mathrm{~cm}$ in length. The length of the tubing need only be measured approximately, sirce previous work (Beck et al. 1996) has shown that the gamma detector is sensitive to cesium (barium) gammas only in a small cone $(6 \mathrm{~cm}$ diameter at sample) below the probe. An "initial concentration $\left(\mathrm{C}_{0}\right)$ " standard will be made up similarly by filling the tubing with feed material. Calibration responses from prepared standards will be entered into a controlled laboratory notebook.

\subsection{TEST PREPARATION AND RUN}

Th is portion of the test plan is intended to provide explicit instructions and expectations of the conduct of ion exchange with the apparatus using crystalline silicotitanate. The expectations are that the $50 \%$ breakthrough will be at approximately 1500 column volumes $\left(\lambda_{511 \%}=1500 \mathrm{CV}\right)$. The run is expected to be conducted for up to 4000 column volumes, sampled every 100 column volumes. Sampling frequency may be revised in accord with $\S$ 5.1. Calibrated standards prepared for prior work (Hendrickson et al. 1996) may be applied. 


\subsubsection{Exchange Column Preparation}

Bcth test columns, $\mathrm{C} 1 \mathrm{a}$ and $\mathrm{C} 1 \mathrm{~b}$, and the guard columns, $\mathrm{C} 2$ and $\mathrm{C} 3$, will be charged with CST and conditioned outside of the hot cell. After conditioning and pump calibration, the columns and system will be transferred into the hot cell. To prepare the CST, manufacturer's specifications will be met with fines removal and sodium hydroxide conditioning. These specifications are not incorporated herein as they are business confidential instructions, but are provided to test personnel.

Use Sheet 14 to prepare and measure the bed density of the sorbent.

FCllowing this conditioning and the following pump calibration, the test assembly will be prepared for hot cell placement.

\subsubsection{CST Apparatus Pump Curve Acquisition}

Because of the varying pressure drops across the apparatus dependent upon sampling location, pump curves will be developed with the loaded columns while feeding $0.50 \underline{\mathrm{M}}$ $\mathrm{N} \mathrm{c}_{\iota} \mathrm{OH}$. This fluid, used in sorbent conditioning, is also expected to well represent the density and viscosity of waste feed. Following the pump curve acquisition, the flow settings configuration (Config. 4) may be used to ensure adequate flow at the apparatus terminus (line 11).

Use Sheet 3 to record and conduct this procedure

- Tare receiver bottle $(\sim 250 \mathrm{~mL})$

- Place line L1 into T3. Place line 11 into tared receiver

- Set valve positions per Sheet 3

Repeat this procedure, for a total of at least three point calibration, at flow settings of approximately $10 \%, 40 \%$, and $60 \%$ of pump knob range.

\subsubsection{CST Waste Feed Preparation and Analysis}

The waste feed will be diluted to a target of approximately $5 \underline{\mathrm{M}} \mathrm{Na}$ and $0.5 \underline{\mathrm{M} \mathrm{OH}}$. Analysis of the waste composition for the feed will be carried out by gamma energy analysis, ion chromatography, TIC, TOC, and inductively coupled plasma at 222-S, in addition to inductively coupled plasma mass spectrometry conducted on similar samples acquired for privatization (DOE 1996) for speciation of cesium.

It is anticipated that the saltcake will be delivered to the 1F Hot Cell in $250 \mathrm{~mL}$ bottles, any dissolved material will remain stoppered. The waste material may be delivered to the hot cell at unspecified times. No time constraint for this work applies with the exception that test run $(\$ 4.2 .5 .5)$ cannot proceed unless the material is prepared.

Use Sheet(s) 4 to record and conduct this procedure. To ensure a homogeneous feed stream 
throughout the run, the $1 \mathrm{~L}$ batches will be prepared by tank source. The prepared feed liquor will then be composited in a $3.8 \mathrm{~L}$ vessel. A total of five batches will be prepared in this manner. Two samples will be withdrawn for analysis.

\subsubsection{System Flush}

After the system is set up in the hot cell, begin the test by setting pump rates and flushing the system.

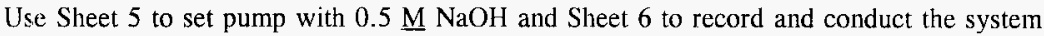
flush for each lead column.

\section{Set Pump:}

Objective: $6 \mathrm{CV} / \mathrm{hr}=16.1 \mathrm{~mL} / \mathrm{hr}$

- Tare receiver bottle $(\sim 100 \mathrm{~mL}$ capacity)

- Place line L1 into T3 (0.5 $\mathrm{M} \mathrm{NaOH})$

- Place Line 12 into tared receiver

- Set valve positions to: Config. 4. Confirm and record valving alignment.

- Set flow rate - turn on pump, measure for 15 min. Check against objective, record results.

- Reset to get to objective as necessary, repeat.

- When at objective, confirm flow with two more test periods.

- Shut down pump

Flush:

- Place Line 11 into tared receiver

- Place Line L1 into T3 (0.5 $\mathrm{M} \mathrm{NaOH})$

- Place System Valving in Config. 1 using the first available lead column. Confirm and record valving alignment.

- Turn on pump and run for 2 hours. Record time on/off, flowrate and feed source.

- Close and confirm closure of all valves.

The $0.5 \mathrm{M} \mathrm{NaOH}$ from the conditioning phase $(\$ 4.2 .1)$ will have been flushed through the column and testing for ${ }^{137} \mathrm{Cs}$ removal may begin.

\subsubsection{Cesium Removal Test Run}

Although it is anticipated that breakthrough $\left({ }^{137} \mathrm{Cs} \mathrm{C} / \mathrm{C}_{4}=0.5\right)$ will occur at $900 \mathrm{CV}$, the test run will schedule use of $4100 \mathrm{CV}$ to ensure data past breakthrough will be obtained. The test will proceed until $\mathrm{C} / \mathrm{C}_{0} \geq 0.7$ and will be discontinued by direction of the lead engineer or chemist. If the $\mathrm{Clb}$ column has not been contacted with a waste feed under consideration, then it will be possible to contact the $\mathrm{Clb}$ column with another waste and essentially replicate the process. If this occurs, the same structure for sampling and sample nomenclature will be carried out (following the schedule of 4.2.5.1 to 4.2.5.4), the time factor will be reset to zero. 


\subsubsection{Gamma Detector Data Logging}

During the test run, the gamma detector will be continuously monitoring the effluent line and recording data on an IBM compatible computer using the GammaVision program. The breakthrough of ${ }^{137} \mathrm{Cs}$ will be indicated by the increase in gamma response over time for the window of $\sim 610-680 \mathrm{KeV}$. The detector logging should commence with initial feed startup $(\$ 4.2 .5 .5)$ and discontinue with final sample acquisition from the flow stream following the test column. Initial estimate for counting periods is $20 \mathrm{~min}$.

The gamma probe must provide an additional function for this component of the test. If the response from the gamma probe indicates $\mathrm{C} / \mathrm{C}_{0}>0.20$ prior to $500 \mathrm{CV}$, the sample regime will accelerate to one sample per $50 \mathrm{CV}$. Sufficient detector shielding will be provided to ensure that cesium loading on columns does not adversely effect detector background. The gamma probe will be read as detailed in Gamma 1 (pg. 17). Detailed instructions for the Gamma probe operation are contained in Appendix D.

\subsubsection{Primary Column Sampling}

All samples will be recorded with column number, date time/group, sample sequence number (SC1E-1, SC1E-2, ...SC1E-n).

It is anticipated that the CST sorbent will be exposed to a minimum of $2000 \mathrm{CV}$ before the test is stopped. Samples of $5 \mathrm{~mL}$ each will be taken at Valve 13. At $200 \mathrm{CV}$ with a flow rate of $6 \mathrm{CV} / \mathrm{h}$, the test will run for 333 hours. The first sample will be taken at 1 hour, representing the effluent stream front. Additional samples will be taken every 16 hours and 40 minutes $(100 \mathrm{CV}$ ) through $4000 \mathrm{CV}$ should the test extend to that duration. Should on line counts exceed $20 \% \mathrm{C}_{0}$, then the accelerated sample of structure of every 8 hours and 20 minutes $(50 \mathrm{CV})$ will be followed. Expected samples total 42 and are detailed on Table 4. Should the on-line gamma detector indicate that the cesium $\mathrm{C} / \mathrm{C}_{0}$ exceeds $20 \%$ under early contact times, an accelerated sample regime may be activated. Reduction of sampling may occur if the rate of change is lower than antcipated. Change procedures of $\$ 5.0$ will be implemented to generate new sampling runtimes in the event of accelerated sampling needs.

Samples shall be acquired as detailed in Table 4. Sampling shall be conducted using Sheet 7 for: sample acquisition data and Sheet 8 for process parameters of the sample.

If the system flow rate varies from the target flow by $> \pm 10 \%$, reset the pump through change procedures in $\S 5.0$. It must be recalled that system target flow rates are established as rates of effluent following the guard columns. With the guard columns out of the flow path during sampling, it is expected that flows from the sample point will be slightly higher than they would be with the added pressure drop across the guard column. Hence, the pump curves of Sheet 3 are required to appropriately monitor flow.

\subsubsection{Secondary Column Sampling}

All samples will be recorded with column number, date time/group, sample sequence number 


\section{Reading the Gamma probe:}

The instrument computer (in the $19^{\prime \prime}$ instrument rack) should be set up with Notepad ${ }^{\text {tm }}$ rumning.

If Notepad ${ }^{\text {tm }}$ is not running, start it by clicking its icon in the Program manager, or AltTAB to switch to Notepad ${ }^{\text {m }}$

With the Notepad ${ }^{\text {th }}$ window open, select OPEN from the FILE menu.

Go to the directory C:lpractjob

Open the highest numbered file that starts with cs\#

It should look like

$$
\text { cs\#003.txt }
$$

with different numbers.

Read the GROSS value. Compare the Gross value with the values posted on the face of the computer or in the notebook. Note the time the file was created (at the top of the file). Record the result on Sheet 8 (if reading during a sampling) and/or on a separately provided data sleet.

If the number is $20 \%$ or greater of the original concentration value, notify the cognizant scientist. Sampling frequency may need to be increased.

If the number is $50 \%$ or greater of the original concentration value, notify the cognizant scientist. The experiment is nearly finished.

\section{Gamma 1: Gamma Probe Reading Procedure}

\section{(SC2E-1, SC2E-2, ...SC2E-n).}

It is anticipated that the CST sorbent will be exposed to $1850 \mathrm{CV}$ before the test is stopped. Samples of $5 \mathrm{~mL}$ each will be taken at Line 14 . At $1850 \mathrm{CV}$ with a flow rate of $6 \mathrm{CV} / \mathrm{h}$, the test will run for 308 hours. The first sample will be taken at 17 hours and 10 minutes, representing the effluent stream front. Additional samples will be taken every 33 hours and 20 minutes $(200 \mathrm{CV})$ until test completion.

Samples shall be acquired as detailed in Table 5 .

Sampling shall be conducted using Sheet 9 for sample acquisition data and Sheet 10 for 
T'able 4: CST Test Run Primary Column Sampling

\begin{tabular}{||l|c|l|l||}
\hline Sample & $\begin{array}{c}\text { Projected Run } \\
\text { Time }\end{array}$ & Sample & $\begin{array}{c}\text { Projected Run } \\
\text { Time }\end{array}$ \\
\hline SC1E-1 & $1 \mathrm{hr} 0 \mathrm{~min}$ & SC1E-22 & $351 \mathrm{hr} 0 \mathrm{~min}$ \\
\hline SC1E-2 & $17 \mathrm{hr} 40 \mathrm{~min}$ & SC1E-23 & $367 \mathrm{hr} 40 \mathrm{~min}$ \\
\hline SC1E-3 & $34 \mathrm{hr} 20 \mathrm{~min}$ & SC1E-24 & $384 \mathrm{hr} 20 \mathrm{~min}$ \\
\hline SC1E-4 & $51 \mathrm{hr} 0 \mathrm{~min}$ & SC1E-25 & $401 \mathrm{hr} 0 \mathrm{~min}$ \\
\hline SC1E-5 & $67 \mathrm{hr} 40 \mathrm{~min}$ & SC1E-26 & $417 \mathrm{hr} 40 \mathrm{~min}$ \\
\hline SC1E-6 & $84 \mathrm{hr} 20 \mathrm{~min}$ & SC1E-27 & $434 \mathrm{hr} 20 \mathrm{~min}$ \\
\hline SC1E-7 & $101 \mathrm{hr} 0 \mathrm{~min}$ & SC1E-28 & $451 \mathrm{hr} 0 \mathrm{~min}$ \\
\hline SC1E-8 & $117 \mathrm{hr} 40 \mathrm{~min}$ & SC1E-29 & $467 \mathrm{hr} 40 \mathrm{~min}$ \\
\hline SC1E-9 & $134 \mathrm{hr} 20 \mathrm{~min}$ & SC1E-30 & $484 \mathrm{hr} 20 \mathrm{~min}$ \\
\hline SC1E-10 & $151 \mathrm{hr} 0 \mathrm{~min}$ & SC1E-31 & $501 \mathrm{hr} 0 \mathrm{~min}$ \\
\hline SC1E-11 & $167 \mathrm{hr} 40 \mathrm{~min}$ & SC1E-32 & $517 \mathrm{hr} 40 \mathrm{~min}$ \\
\hline SC1E-12 & $184 \mathrm{hr} 20 \mathrm{~min}$ & SC1E-33 & $534 \mathrm{hr} 20 \mathrm{~min}$ \\
\hline SC1E-13 & $201 \mathrm{hr} 0 \mathrm{~min}$ & SC1E-34 & $551 \mathrm{hr} 0 \mathrm{~min}$ \\
\hline SC1E-14 & $217 \mathrm{hr} 40 \mathrm{~min}$ & SC1E-35 & $567 \mathrm{hr} 40 \mathrm{~min}$ \\
\hline SC1E-15 & $234 \mathrm{hr} 20 \mathrm{~min}$ & SC1E-36 & $584 \mathrm{hr} 20 \mathrm{~min}$ \\
\hline SC1E-16 & $251 \mathrm{hr} 0 \mathrm{~min}$ & SC1E-37 & $601 \mathrm{hr} 0 \mathrm{~min}$ \\
\hline SC1E-17 & $267 \mathrm{hr} 40 \mathrm{~min}$ & SC1E-38 & $617 \mathrm{hr} 40 \mathrm{~min}$ \\
\hline SC1E-18 & $284 \mathrm{hr} 20 \mathrm{~min}$ & SC1E-39 & $634 \mathrm{hr} 20 \mathrm{~min}$ \\
\hline SC1E-19 & $301 \mathrm{hr} 0 \mathrm{~min}$ & SC1E-40 & $651 \mathrm{hr} 0 \mathrm{~min}$ \\
\hline SC1E-20 & $317 \mathrm{hr} 40 \mathrm{~min}$ & SC1E-41 & $667 \mathrm{hr} 40 \mathrm{~min}$ \\
\hline SC1E-21 & $334 \mathrm{hr} 20 \mathrm{~min}$ & SC1E-42 & $684 \mathrm{hr} 20 \mathrm{~min}$ \\
\hline \hline
\end{tabular}

Table 5: CST Test Run Secondary Column Sampling

\begin{tabular}{||l|l|l|l||}
\hline Sample & $\begin{array}{c}\text { Projected Run } \\
\text { Time }\end{array}$ & Sample & $\begin{array}{c}\text { Projected Run } \\
\text { Time }\end{array}$ \\
\hline SC2E-1 & $17 \mathrm{hr} 10 \mathrm{~min}$ & SC2E-11 & $350 \mathrm{hr} 30 \mathrm{~min}$ \\
\hline SC2E-2 & $50 \mathrm{hr} 30 \mathrm{~min}$ & SC2E-12 & $383 \mathrm{hr} 50 \mathrm{~min}$ \\
\hline SC2E-3 & $83 \mathrm{hr} 50 \mathrm{~min}$ & SC2E-13 & $417 \mathrm{hr} 10 \mathrm{~min}$ \\
\hline SC2E-4 & $117 \mathrm{hr} 10 \mathrm{~min}$ & SC2E-14 & $450 \mathrm{hr} 30 \mathrm{~min}$ \\
\hline SC2E-5 & $150 \mathrm{hr} 30 \mathrm{~min}$ & SC2E-15 & $483 \mathrm{hr} 50 \mathrm{~min}$ \\
\hline SC2E-6 & $183 \mathrm{hr} 50 \mathrm{~min}$ & SC2E-16 & $517 \mathrm{hr} 10 \mathrm{~min}$ \\
\hline SC2E-7 & $217 \mathrm{hr} 10 \mathrm{~min}$ & SC2E-17 & $550 \mathrm{hr} 30 \mathrm{~min}$ \\
\hline SC2E-8 & $250 \mathrm{hr} 30 \mathrm{~min}$ & SC2E-18 & $583 \mathrm{hr} 50 \mathrm{~min}$ \\
\hline SC2E-9 & $283 \mathrm{hr} 50 \mathrm{~min}$ & SC2E-19 & $617 \mathrm{hr} 10 \mathrm{~min}$ \\
\hline SC2E-10 & $317 \mathrm{hr} 10 \mathrm{~min}$ & SC2E-20 & $650 \mathrm{hr} 30 \mathrm{~min}$ \\
\hline
\end{tabular}

process parameters of the sample. 


\subsubsection{System Effluent Sampling}

The sampling from the second guard column (C3) will be of composite materials. At test initiation place a $1 \mathrm{~L}$ container under V14/11. This volume should be sufficient for approximately 60 hours of operation. Replace this container when it has reached $75 \%$ of capacity or will do so by the next sampling effort. At the end of the run, take an aliquot of approximately $5 \mathrm{~mL}$ from each container. Identify the samples as SC3E-1 to SC3E-n, where $\mathrm{n}$ is the container number (should not exceed 8).

\subsubsection{Run Execution}

Use Sheet 6 to record and conduct this procedure

Confirm or do:

Objective: $6 \mathrm{CV} / \mathrm{hr}=16.1 \mathrm{~mL} / \mathrm{hr}$

- Tare receiver bottle (1L)

- Place Line 11 into $1 \mathrm{~L}$ collection vessel

- Place line L1 into T2 (Waste Feed)

- Confirm valving for Config. 1. Confirm and record valving alignment on Sheet 6 .

- Measure and record feed temperature $\left({ }^{\circ} \mathrm{C}\right)$

- Turn on pump and initiate test runtime clock. Record test initiation on Sheet 6.

- Acquire data and samples as directed above.

- Continue flow until $\gamma$ probe response is beyond $\sim 70 \% \mathrm{C} / \mathrm{C}_{0}$.

- Immediately following last primary column sample, shut down pump, and take the composite effluent samples from the receivers filled below V14/11.

- Close and confirm closure of all valves.

\subsubsection{System Flush}

After the feed solution has run through the system, the system will be flushed with $0.5 \underline{\mathrm{M}}$ $\mathrm{NaOH}$ for $15 \mathrm{CV}$ at $6 \mathrm{CV} / \mathrm{h}$ (2.5 hours). Allow the flush to run to the flush receiver.

Use Sheet 6 to record and conduct this procedure.

- Wash exterior of Line L1 with $\mathrm{H}_{2} \mathrm{O}$, place $\mathrm{L} 1$ in $\mathrm{T} 3(0.5 \mathrm{M} \mathrm{NaOH})$

- Place 11 into flush waste receiver (1L)

- Establish valving for Config. 1. Confirm and record valving alignment.

- Turn on pump for 2.5 hours. Record start time.

- Turn off pump. Record stop time

- Close and confirm closure of all valves.

DURING THE TEST RUN, ALL SAMPLE POINTS (LINES 12A/B, 13, 14, 11) WILL HAVE A CATCH CONTAINER TO CONTAIN SPILLS.

ALL VALVING CONFIGURATIONS REQUIRE THAT ALL VALVES NOT SPECIFIED AS OPEN SHALL BE CLOSED 
No samples will be taken of this waste.

\subsection{SYSTEM CLEANOUT AND WASTE MANAGEMENT}

The application of this section is to minimize the volume and form of waste to be disposed from the hot cells. Wastes shall be handled in accordance with WAC 173-303 (Ecology 1994).

\subsubsection{Thermolabile Wastes}

All poly tubing, thermoplastics, etc. that will melt are to be placed in a metal container. The container will then be placed on a hot plate and the material melted in accordance with appropriate procedure (LO-100-106, Marshall 1994), the can cooled and sealed and disposed in accordance with WAC 173-303. (WDOE 1994)

\subsubsection{Sorbent Columns}

Use Sheet 13 for spent CST dissolution procedure and record.

Prior to removing the columns, confirm the following valve positions:

$\begin{array}{lll}\text { C1a } & \text { V4a \& V5a } & \text { closed } \\ \text { C1b } & \text { V4b \& V5b } & \text { closed } \\ \text { C2 } & \text { V9 \& V10 } & \text { closed } \\ \text { C3 } & \text { V12 \& V13 } & \text { closed }\end{array}$

These valves are the isolation valves for the columns. When removing the columns, the tubing should be crimped to inhibit leaks. The material in the columns should, be removed from the columns by removing the top of the column and rinsing and scraping the sorbent into a receiver.

Remove the sorbent from $\mathrm{Cla}$ or $\mathrm{Clb}$ and digest proportionately to Sheet 23 observations. Digest $\mathrm{C} 2$ and $\mathrm{C} 3$ in the same manner, no samples are to be taken. All columns should be dissolved together in one batch.

Remaining dissolved exchange material solutions are to be poured down the hot cell drain.

\subsubsection{Other Liquors}

Effluent materials from test conduct, acquired at line 11, are to be retained, in separate,

DURING THE TEST RUN, ALL SAMPLE POINTS (LINES 12A/B, 13, 14, 11) WILL HAVE A CATCH CONTAINER TO CONTAIN SPILLS.

\section{ALL VALVING CONFIGURATIONS REQUIRE THAT ALL VALVES NOT SPECIFIED AS OPEN SHALL BE CLOSED}


labeled, 1 liter bottles. These materials will be shipped to PNNL for additional anionic exchange studies.

Waste flushes and washes are to be poured down the hot cell drain. Unanalyzed samples, unless otherwise specified at test close out, are to be poured down the hot cell drain. Unused diluted waste feed, unless otherwise specified at test close out, are to be poured down the hot cell drain. Unused and undiluted waste feed is to be returned to archive.

\subsubsection{Other Solid Wastes}

Other solid wastes will include the glass exchange columns, valves, fittings, and glassware for material handling. This material should be triple rinsed and packaged for disposal. Pour rirse liquors down hot cell drain.

\subsection{SAMPLING AND SAMPLE ANALYSES}

Analytical sample selection for analyses of feed wastes, effluents; digest, and eluates are presented in Table 6. Rubidium, potassium, strontium, and cesium isotopic analyses are to be conducted by inductively coupled plasma mass spectroscopy (ICP-MS); hydroxide by potentiometric titration or specific ion electrode, other metals $(\mathrm{Na}, \mathrm{Al}, \mathrm{K}, \mathrm{Cr}, \mathrm{Fe}, \mathrm{P})$ are to by analyzed by inductively coupled plasma atomic emission spectroscopy (ICP-AES), transuranic metals ( $\mathrm{Am}, \mathrm{Pu}, \mathrm{Np}$ ) are to be analyzed by alpha emission analysis (AEA), and ${ }^{137} \mathrm{Cs}$ and ${ }^{134} \mathrm{Cs}$ by gamma energy analysis (GEA). Selected waste feeds and effluents will be analyzed for total organic carbon by TOC, total inorganic carbon, and for nitrate, nitrite, flcoride, chloride, and sulfate by ion chromatography. Test conduct will include on-line gamma analysis.

\begin{tabular}{|c|c|c|c|c|c|c|c|c|c|c|c|}
\hline \multirow{2}{*}{ Sample } & Method & \multirow{2}{*}{ ICP-MS } & \multirow{2}{*}{ ICP-AES } & \multirow{2}{*}{ GEA } & \multirow{2}{*}{$\triangle \mathrm{EA}$} & \multirow{2}{*}{ IC } & \multirow{2}{*}{ TIC } & \multirow{2}{*}{ TOC } & \multirow{2}{*}{$\mathrm{OH}-$} & \multirow{2}{*}{ Density } & \multirow{2}{*}{ On-line $\gamma$} \\
\hline & Description & & & & & & & & & & \\
\hline St-ake-1 & Saltcake solids & $\mathrm{x}$ & $\mathrm{x}$ & $\mathrm{X}$ & & & & & & & \\
\hline SI-ake-2 & Saltcake solids & $x$ & $\mathrm{X}$ & $\mathrm{X}$ & & & & & & & \\
\hline Sicake-3 & Saltcake solids & $\mathrm{x}$ & $\mathrm{x}$ & $x$ & & & & & & & \\
\hline $\mathrm{CI}: \mathrm{I}$ & Waste Feed & $\mathrm{x}$ & $\mathrm{X}$ & $\mathrm{X}$ & $\mathrm{X}$ & $\mathrm{x}$ & $\mathrm{x}$ & $x$ & $\mathrm{x}$ & $\mathrm{X}$ & \\
\hline $\mathrm{Cl} 2$ & Waste Feed & & $x$ & $\mathrm{X}$ & $\mathrm{X}$ & $\mathrm{x}$ & $x$ & $\mathrm{x}$ & $\mathrm{X}$ & & \\
\hline $\mathrm{Cl}: 3$ & Waste Feed & $x$ & $x$ & $\mathrm{X}$ & $\mathrm{X}$ & $x$ & $x$ & $\mathrm{X}$ & $\mathrm{X}$ & $\mathrm{X}$ & \\
\hline $\mathrm{CI} 4$ & Waste Feed & & $x$ & $\mathrm{X}$ & $\mathrm{X}$ & $\mathrm{X}$ & $\mathrm{x}$ & $\mathrm{X}$ & $\mathrm{X}$ & & \\
\hline $\mathrm{Cl} 5$ & Waste Feed & $\mathrm{X}$ & $x$ & $\mathrm{X}$ & $\mathrm{X}$ & $\mathrm{X}$ & $x$ & $\mathrm{X}$ & $\mathrm{X}$ & $\mathrm{X}$ & \\
\hline CF 6 & Waste Feed & & $x$ & $\mathrm{X}$ & $\mathrm{X}$ & $\mathrm{X}$ & $\mathrm{x}$ & $\mathrm{X}$ & $\mathrm{X}$ & & \\
\hline CISI & Centrifuge sids & & $\mathrm{x}$ & $\mathrm{X}$ & $\mathrm{X}$ & & & & & & \\
\hline $\mathrm{CIS} 2$ & Centrifuge slds & & & & $\mathrm{X}$ & & & & & & \\
\hline $\mathrm{CIS3}$ & Centrifuge sids & & $\mathrm{x}$ & $\mathrm{x}$ & $\mathrm{X}$ & & & & & & \\
\hline $\mathrm{ClS} 4$ & Centrifuge sids & & & & $\mathrm{X}$ & & & & & & \\
\hline Cls 5 & Centrifuge sids & & $\mathrm{X}$ & $\mathrm{X}$ & $\mathrm{X}$ & & & & & & \\
\hline
\end{tabular}


HNF-SD-RE-TPI-003, Rev. 0

\begin{tabular}{|c|c|c|c|c|c|c|c|c|c|c|c|}
\hline \multirow{2}{*}{ Sample } & Method & \multirow{2}{*}{ ICP-MS } & \multirow{2}{*}{ ICP-AES } & \multirow{2}{*}{ GEA } & \multirow{2}{*}{ AEA } & \multirow{2}{*}{ IC } & \multirow{2}{*}{ TIC } & \multirow{2}{*}{ TOC } & \multirow{2}{*}{$\mathrm{OH}-$} & \multirow{2}{*}{ Density } & \multirow{2}{*}{ On-line $\gamma$} \\
\hline & Description & & & & & & & & & & \\
\hline CFS6 & Centrifuge slds & & & & $\mathrm{X}$ & & & & & & \\
\hline SCIE-1 & $\mathrm{Cl} \mathrm{a} / \mathrm{b}$ Effluent & & $\mathrm{X}$ & $\mathrm{x}$ & & $\mathrm{X}$ & $\mathrm{X}$ & & $\mathrm{X}$ & & $\mathrm{X}$ \\
\hline SCIE-2 & $\mathrm{Cla} / \mathrm{b}$ Effluent & & $\mathrm{X}$ & $\mathrm{X}$ & & & & & & $\mathrm{x}$ & $\mathrm{X}$ \\
\hline SCIF- 3 & $\mathrm{Cla} / \mathrm{b}$ Eflluent & & $x$ & $\mathrm{X}$ & & $X$ & $\mathrm{x}$ & & $\mathrm{X}$ & & $\mathrm{x}$ \\
\hline Sc $1 \mathrm{~L}-4$ & C1a/b Leffluent & & $x$ & $\mathrm{x}$ & & & & & & & $\mathrm{x}$ \\
\hline$S t-1 E-5$ & $\mathrm{Cla} / \mathrm{b}$ Effluent & & $\mathrm{x}$ & $\mathrm{X}$ & & $\mathrm{X}$ & $\mathrm{X}$ & & $\mathrm{X}$ & & $\mathrm{x}$ \\
\hline SC1E-6 & $\mathrm{Cla} / \mathrm{b}$ Eflluent & & $\mathrm{x}$ & $\mathrm{X}$ & & & & & & & $\mathrm{x}$ \\
\hline SC1E-7 & $\mathrm{Cla} / \mathrm{b}$ Effluent & & $\mathrm{X}$ & $\mathrm{x}$ & & $\mathrm{x}$ & $\mathrm{X}$ & & $\mathrm{X}$ & & $x$ \\
\hline SE $1 E-8$ & $\mathrm{Cla} / \mathrm{b}$ Effluent & & $\mathrm{x}$ & $\mathrm{X}$ & & & & & & $\mathrm{x}$ & $x$ \\
\hline SEIE-9 & $\mathrm{Cla}$ b Efflucnt & & $\mathrm{X}$ & $\mathrm{x}$ & & $\mathrm{x}$ & $\mathrm{X}$ & & $\mathrm{X}$ & & $\mathrm{x}$ \\
\hline SC1E-10 & $\mathrm{Cla}$ b Effluent & & $\mathrm{X}$ & $\mathrm{x}$ & & & & & & & $\mathrm{x}$ \\
\hline SCIE-11 & Cla/b Efflucnt & & $\mathrm{X}$ & $\mathrm{X}$ & & $\mathrm{X}$ & $\mathrm{X}$ & & $\mathrm{X}$ & & $\mathrm{x}$ \\
\hline SCIE- 12 & $\mathrm{Cla} b$ Efflucit & & $\mathrm{X}$ & $\mathrm{X}$ & & & & & & & $\mathrm{X}$ \\
\hline SI 1E-13 & Cla/b Effluent & & $\mathrm{X}$ & $\mathrm{X}$ & & $\mathrm{X}$ & $\mathrm{X}$ & & $\mathrm{X}$ & & $x$ \\
\hline SC1E- 14 & $\mathrm{Cla} / \mathrm{b}$ Effluent & & $\mathrm{X}$ & $\mathrm{X}$ & & & & & & $\mathrm{X}$ & $x$ \\
\hline SCIE-15 & $\mathrm{Cla} / \mathrm{b}$ Eftluent & & $\mathrm{X}$ & $\mathrm{X}$ & & $\mathrm{X}$ & $\mathrm{X}$ & & $x$ & & $x$ \\
\hline SCIE-16 & $\mathrm{C} 1 \mathrm{a} / \mathrm{b}$ Ettluent & & & $\mathrm{X}$ & & & & & & & $x$ \\
\hline$S 1=1 E-17$ & $\mathrm{C} 1 \mathrm{a} / \mathrm{b}$ Effluent & & & $\mathrm{X}$ & & & & & & & $\mathrm{x}$ \\
\hline SCIE] 8 & $\mathrm{Cla} / \mathrm{l}$ Ettluent & & & $\mathrm{X}$ & & & & & & & $\mathrm{x}$ \\
\hline SCIE-19 & $\mathrm{Cla} / \mathrm{b}$ Effluent & & & $\mathrm{X}$ & & & & & & & $\mathrm{x}$ \\
\hline SCIE-20 & $\mathrm{Cla} / \mathrm{b}$ Effluent & & $\mathrm{x}$ & $\mathrm{X}$ & & $\mathrm{X}$ & $\mathrm{x}$ & & $x$ & $x$ & $\mathrm{x}$ \\
\hline$S C[E-2]$ & C1a/b Effluent & & & $x$ & & & & & & & $\mathrm{X}$ \\
\hline SCIE- 22 & $\mathrm{Cla} / \mathrm{b}$ Effluent & & & $\mathrm{X}$ & & & & & & & $\mathrm{x}$ \\
\hline SCIE-23 & $\mathrm{Cla} / \mathrm{b}$ Effluent & & & $\mathrm{X}$ & & & & & & & $\mathrm{X}$ \\
\hline SCIE-24 & Cla/b Effluent & & & $x$ & & & & & & & $\mathrm{x}$ \\
\hline SCIE-25 & $\mathrm{Cla} / \mathrm{b}$ Effluent & & $\mathrm{X}$ & $\mathrm{X}$ & & $\mathrm{x}$ & $\mathrm{x}$ & & $\mathrm{X}$ & & $\mathrm{X}$ \\
\hline SC:L-26 & Cla/h Eftluent & & & $\mathrm{X}$ & & & & & & & $x$ \\
\hline SCIE-27 & Cla/b Effluent & & & $\mathrm{X}$ & & & & & & & $\mathrm{X}$ \\
\hline St $1 E-28$ & Cla/s Eftluent & & & $\mathrm{x}$ & & & & & & & $\mathrm{x}$ \\
\hline Sc1E-29 & $\mathrm{Cla} / \mathrm{b}$ Effluent & & & $\mathrm{X}$ & & & & & & & $\mathrm{x}$ \\
\hline St 1 E-30 & $C 1 \mathrm{a} / \mathrm{b}$ Effluent & & $\mathrm{x}$ & $\mathrm{X}$ & & $\mathrm{X}$ & $\mathrm{x}$ & & $\mathrm{X}$ & $\mathrm{x}$ & $\mathrm{x}$ \\
\hline St 1L-31 & $\mathrm{Cla} / \mathrm{b}$ Effluent & & & $\mathrm{X}$ & & & & & & & $\mathrm{X}$ \\
\hline Sc 1 E- 32 & $\mathrm{Cla} / \mathrm{b}$ Effluent & & & $\mathrm{x}$ & & & & & & & $\mathrm{x}$ \\
\hline ST 1 E- 33 & $\mathrm{C} 1 \mathrm{a} / \mathrm{b}$ Effluent & & & $\mathrm{X}$ & & & & & & & $\mathrm{x}$ \\
\hline $\mathrm{St} 1 \mathrm{E}-34$ & Cla/h Etfluent & & & $\mathrm{X}$ & & & & & & & $\mathrm{X}$ \\
\hline St $1 \mathrm{E}-35$ & $\mathrm{C} 1 \mathrm{a} / \mathrm{b}$ Effluent & & $\mathrm{X}$ & $\mathrm{X}$ & & $\mathrm{X}$ & $\mathrm{x}$ & & $\mathrm{x}$ & & $\mathrm{x}$ \\
\hline St-1E-36 & $\mathrm{Cla} / \mathrm{b}$ Effluent & & & $\mathrm{x}$ & & & & & & & $\mathrm{X}$ \\
\hline St $1 \mathrm{E}-37$ & C1a/́ Effluent. & & & $\mathrm{X}$ & & & & & & & $\mathrm{x}$ \\
\hline$S E-1 E-38$ & $\mathrm{Cla} / \mathrm{b}$ Effluent & & & $\mathrm{X}$ & & & & & & & $\mathrm{x}$ \\
\hline
\end{tabular}


HNF-SD-RE-TPI-003, Rev. 0

\begin{tabular}{|c|c|c|c|c|c|c|c|c|c|c|c|}
\hline & & Table 6: & sium Ion $\mathrm{E}$ & hange & mmary & ampl & Analy & Plan & & & \\
\hline \multirow{2}{*}{ Sample } & Method & \multirow{2}{*}{ ICP-MS } & \multirow{2}{*}{ ICP-AES } & \multirow{2}{*}{ GEA } & \multirow{2}{*}{$A E A$} & \multirow{2}{*}{ IC } & \multirow{2}{*}{ TIC } & \multirow{2}{*}{ TOC } & \multirow{2}{*}{$\mathrm{OH}-$} & \multirow{2}{*}{ Density } & \multirow{2}{*}{ On-line $\gamma$} \\
\hline & Description & & & & & & & & & & \\
\hline SCIE-39 & Cla/b Effluent & & & $\mathrm{X}$ & & & & & & & $x$ \\
\hline SC-1E-40 & $\mathrm{Cla} / \mathrm{b}$ Effluent & & $\mathrm{x}$ & $x$ & & $\mathrm{X}$ & $\mathrm{X}$ & & $\mathrm{x}$ & $\mathrm{x}$ & $x$ \\
\hline SC $\mid E-41$ & $\mathrm{C} 1 \mathrm{a} / \mathrm{b}$ Effluent & & & $\mathrm{X}$ & & & & & & & $\mathrm{X}$ \\
\hline $\mathrm{SC}-1 \mathrm{E}-42$ & Cla/b Effluent & & $\mathrm{X}$ & $\mathrm{X}$ & & $\mathrm{X}$ & $\mathrm{X}$ & & $\mathrm{X}$ & & $\mathrm{X}$ \\
\hline SC2E-1 & C2 Effluent & & & $\mathrm{x}$ & & & & & & & \\
\hline ST $2 \mathrm{E}-2$ & C2 Effluent & & & $\mathrm{X}$ & & & & & & & \\
\hline SC2E-3 & C2 Effluent & & & $\mathrm{x}$ & & & & & & & \\
\hline $\mathrm{SC} 2 \mathrm{E}-4$ & C2 Effluent & & $\mathrm{X}$ & $\mathrm{X}$ & & $\mathrm{X}$ & $\mathrm{X}$ & & $X$ & $x$ & \\
\hline $\mathrm{SC}-2 \mathrm{E}-5$ & C2 Effluent & & & $\mathrm{X}$ & & & & & & & \\
\hline SI $2 E-6$ & C2 Effluent & & & $\mathrm{X}$ & & & & & & & \\
\hline $\mathrm{St}=2 \mathrm{E}-7$ & C2 Effluent & & & $\mathrm{X}$ & & & & & & & \\
\hline St $2 \mathrm{E}-8$ & C2 Effluent & & $\mathrm{X}$ & $\mathrm{X}$ & & $\mathrm{X}$ & $\mathrm{X}$ & & $X$ & & \\
\hline Sc $2 \mathrm{E}-9$ & C2 Effluent & & & $\mathrm{X}$ & & & & & & & \\
\hline SC2L-10 & C.2 Effluent & & & $\mathrm{X}$ & & & & & & & \\
\hline SC.2E-11 & C2 Effluent & & & $\mathrm{X}$ & & & & & & & \\
\hline Si-2E-12 & C2 Effluent & & $\mathrm{X}$ & $\bar{x}$ & & $\mathrm{X}$ & $X$ & & $x$ & $\mathrm{X}$ & \\
\hline St $2 \mathrm{E}-13$ & C2 Effluent & & & $X$ & & & & & & & \\
\hline $\mathrm{SC} 2 \mathrm{E}-14$ & C2 Effluent & & & $\mathrm{X}$ & & & & & & & \\
\hline $\mathrm{SI} 2 \mathrm{E}-15$ & C2 Effluent & & & $\mathrm{X}$ & & & & & & & \\
\hline $\mathrm{S}=2 \mathrm{E}-16$ & C2 Effluent & & & $\mathrm{X}$ & & & & & & & \\
\hline ST $2 \mathrm{E}-17$ & C2 Effluent & & & $x$ & & & & & & & \\
\hline $\mathrm{SI} 2 \mathrm{E}-18$ & C2 Effluent & & & $\mathrm{X}$ & & & & & & & \\
\hline$S C-2 E-19$ & C2 Effluent & & & $\mathrm{X}$ & & & & & & & \\
\hline S1-2E-20 & C2 Effluent & & & $\mathrm{X}$ & & & & & & $\mathrm{X}$ & \\
\hline SC $2 \mathrm{E}-21$ & C2 Effluent & & & $\mathrm{x}$ & & & & & & & \\
\hline SI $3 E-1$ & Comp. C3 Effluent & $\mathrm{X}$ & $\mathrm{X}$ & $\mathrm{X}$ & & $\mathrm{X}$ & $\mathrm{X}$ & $\mathrm{x}$ & & $\mathrm{X}$ & \\
\hline SC $3 E-2$ & Comp. C3 Effluent & & $\mathrm{X}$ & $\mathrm{X}$ & $\mathrm{X}$ & & & & $\mathrm{x}$ & & \\
\hline $\mathrm{SC} 3 \mathrm{E}-3$ & Comp. C3 Eftluent & $\mathrm{X}$ & $\mathrm{X}$ & $\mathrm{X}$ & & $\mathrm{x}$ & $\mathrm{X}$ & $\mathrm{x}$ & & $\mathrm{x}$ & \\
\hline St $3 E-4$ & Comp. C3 Effluent & & $\mathrm{x}$ & $\mathrm{x}$ & $\mathrm{x}$ & & & & $\mathrm{x}$ & & \\
\hline Sr $3 \mathrm{E}-5$ & Comp. $\mathrm{C} 3$ Effluent & $\mathrm{x}$ & $\mathrm{x}$ & $\mathrm{X}$ & & $\mathrm{x}$ & $\mathrm{X}$ & $\mathrm{X}$ & & $\mathrm{X}$ & \\
\hline ST: $3 E-6$ & Comp. C3 Effluent & & $x$ & $\mathrm{X}$ & $\mathrm{X}$ & & & & $x$ & & \\
\hline Si. $3 \mathrm{E}-7$ & Comp. C3 Eftluent & & & $\mathrm{X}$ & & & & & & $\mathrm{X}$ & \\
\hline ST 3E-8 & Comp, C3 Effluent & & $\mathrm{x}$ & $\mathrm{X}$ & & $x$ & $\mathrm{x}$ & $\mathrm{x}$ & & & \\
\hline SL $3 E-9$ & Comp. C3 Effluent & $\mathrm{x}$ & & $\mathrm{X}$ & & & & & & $\mathrm{X}$ & \\
\hline SC3E-10 & Comp. C3 Effluent & & $x$ & $\mathrm{X}$ & $\mathrm{X}$ & & & & $\mathrm{X}$ & & \\
\hline $\mathrm{St}-3 \mathrm{E}-11$ & Comp, C3 Effluent & & & $\mathrm{X}$ & & $\mathrm{X}$ & $\mathrm{x}$ & $\mathrm{x}$ & & $\mathrm{X}$ & \\
\hline St $-3 \mathrm{E}-12$ & Comp. C3 Efthuent & & $\mathrm{X}$ & $\mathrm{X}$ & & & & & $\mathrm{X}$ & & \\
\hline \multicolumn{2}{|c|}{ Tistal Samples/Method } & ICP-MS & ICP-AES & GEA & AEA & IC & TIC & TOC & $\mathrm{OH}-$ & Density & On-line $\gamma$ \\
\hline 313 & & 10 & 45 & 87 & 16 & 28 & 28 & 11 & 28 & 18 & 42 \\
\hline
\end{tabular}




\section{1) CHANGE PROCEDURE}

\subsection{General Changes}

As in any experimental test conduct, the possibility of procedural revision exists. Operating personnel may institute any necessary changes with approval of the lead engineer or chemist. Such change will be documented in an engineering change notice at test completion for configuration control where necessary. All changes will be recorded in the laboratory notebook and reported with test results.

\subsection{Sampling Frequency Change}

Due to the potential of early breakthrough of analytes of interest (i.e. ${ }^{137} \mathrm{Cs}$ ) in test columns, the on-line $\gamma$ detector will be operated to report effluent activities. Should the activity exceed $20 \%$ of breakthrough the operating personnel should contact the lead engineer or chemist and institute a sampling frequency shift if necessary. That shift must be defined in terms of run time (i.e. flow volume). Such change will be recorded in the laboratory notebook and reported with test results.

\subsection{Pump Flow Rate Reset}

Due to the potential of pump flow rate drift through tubing crimping, exchange material degradation, or other causes, the test apparatus flow may depart from the test objective rate. Should the observed rate under $\$ 4.2 .5 .5$, deviate from the object by greater than $10 \%$, the pump rate should be reset to the appropriate rate through procedures on Sheet 5 . The operating personnel may institute the required change with approval of the lead engineer or chemist. Such change will be recorded in the laboratory notebook and reported with test results.

\section{6.) QUALITY ASSURANCE}

Quality assurance requirements are guided by 10 CFR 830.120 Quality Assurance Requirements (DOE 1994a) and by the Implementation Guide for Use with 10 CFR 830.120 (DOE 1994b). The implementation of 10 CFR 830.120 is through the Quality Assurance Manual (WHC 1996) and facility specific quality assurance plans.

Ex.istent quality assurance requirements encompassed by the Quality Assurance Plan (Meznarich 1995) of the laboratory facilities will be met in the conduct of this work and its chemical analyses. The quality assurance for the conduct of the unit operations and hot cell activities will be in accordance with the approved process testing quality assurance plan (Meznarich 1996). 


\section{0) REFERENCES}

Beck, M. A., R. S. Addleman, G. R. Blewitt, E. R. Selle, C. S. McClellan, D. A. Dodd, G. L. Troyer, and B. D. Keele, 1996, Remote Nuclear Screening System for Hostile Environments, WHC-SD-WM-DTR-024, Rev. 0, Westinghouse Hanford Company, Richland, Washington, February 27, 1996.

DOE, 1994a, Nuclear Safety Management, "Quality Assurance Requirements,"

10 CFR 830.120, U. S. Department of Energy, Washington D.C., April 5, 1994.

DOE, 1994b, Implementation Guide for Use with 10 CFR 830.120 Quality Assurance, G-830.120-Rev. 0, U. S. Department of Energy, Washington D.C., April 15, 1994.

Duncan, J. B., D. W. Hendrickson, R. K. Biyani, 1996, Hanford Sincle Shell Tank Saltcake Cesium Removal Test Plan, WHC-SD-RE-TP-024, Rev. 0, SGN Eurisys Services Corporation, Richland, Washington, December 11, 1996.

EF'A, 1986, 40 CFR \$261.31, Hazardous wastes from non-specific sources, U. S. Environmental Protection Agency, Washington, D.C., August 25, 1986.

Hendrickson, D. W., and J. B. Duncan, 1996, Hanford Tank Waste Supernatant Cesium Removal Test Plan, WHC-SD-RE-TP-022, Rev. 0, Westinghouse Hanford, Company, Richland, Washington, May 31, 1996.

Hendrickson, D. W., R. K. Biyani, and M. A. Beck, 1996, Hanford Tank Waste Supernatant Cesium Removal Test Report, WHC-SD-RE-TRP-018, Rev. 0A, Westinghouse Hanford Company, Richland, Washington, October 1, 1996.

Marshall, R. P., 1994, Melting Plastic Material in Cubicles of the 222-S Laboratory, LO-100-106, Westinghouse Hanford Company, Richland, Washington, March 1994.

Meznarich, H. K., 1995, 222-S Laboratory Quality Assurance Plan, WHC-SD-CP-QAPP-016, Rev. 0, Westinghouse Hanford Company, Richland, Washington, July $31,1995$.

Meznarich, H. K., 1996, 222-S Process and Development Laboratory Quality Assurance Plan, WHC-SD-CP-QAPP-018, Rev. 0, Westinghouse Hanford Company, Richland, Washington, June 1996.

Perry, R. H., D. W. Green, J. O. Maloney, Perry's Chemical Engineer's Handbook, Sixth Edition, McGraw-Hill Book Company, New York, New York, 1984.

WDOE, 1994, Washington Administrative Code, Chapter 173-303, Dangerous Waste Regulations, (WAC 173-303), Washington Department of Ecology, Olympia, Washington, January 8, 1994. 
HNF-SD-RE-TPI-003, Rev. 0

Appendix A: Checksheets and Data Sheets 
HNF-SD-RE-TPI-003, Rev. 0

THIS PAGE INTENTIONALLY LEFT BLANK 


\section{LIST OF CHECKSHEETS AND DATASHEETS}

1: Feed System Assembly . . . . . . . . . . . . . . . . A A-1

2: Test Assembly Instructions and Checksheet $\ldots \ldots \ldots \ldots \ldots \ldots \ldots \ldots$ A-3

3: Pump Calibration for the CST Column Test . . . . . . . . . . . . . A-4

4: Waste Feed Preparation . . . . . . . . . . . . . . . . . . A-7

5: Pump Flow Rate Set and Measurement . . . . . . . . . . . . . . . A-9

6: Effluent Collection Record . . . . . . . . . . . . . . . . . . . . A-10

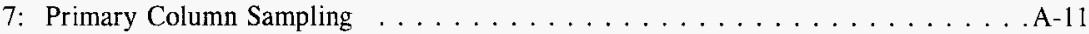

8: Primary Column Sample Record . . . . . . . . . . . . . . . . . . . . . A-12

9: Secondary $(\mathrm{C} 2)$ Column Sampling . . . . . . . . . . . . . . . . . . A-14

10: Secondary (C2) Column Sample Record . . . . . . . . . . . . . . A-15

11: Primary Column $\mathrm{Cla} / \mathrm{b}$ Reverse Feed Valving . . . . . . . . . . A-16

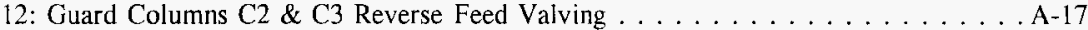

13: CST Sorbent Dissolution . . . . . . . . . . . . . . . . A-18

14: CST Sorbent Bed Density Determination . . . . . . . . . . . . A-19

15: $\mathrm{NaOH}$ Solution Preparation from 5.0 mole/L Stock . . . . . . . . . . . . A-21 
HNF-SD-RE-TPI-003, Rev. 0

THIS PAGE INTENTIONALLY LEFT BLANK

A-iv 
Sheet 1: Feed System Assembly

See Figure A-1 and Figure A-2:

Checksheet\#

Assemble Line $\mathrm{L} 1$ as composite of $1.5 \mathrm{~m}$ Tygon tubing, $0.51 \mathrm{~mm}$ ID, fitted to $10 \mathrm{~cm}$ Tygon tubing, $3.175 \mathrm{~mm}$ ID. Connect $3.175 \mathrm{~mm}$ ID end of $\mathrm{L} 1$ to Valve V1. Mount $0.51 \mathrm{~mm}$ ID segment of L1 through pump head.

Next, to ensure that the feed line is situated about 1 " above the bottom of the feed container, assemble a dip tube for the feed line as follows. Drill a $1 / 4$ " hole and a $1 / 8$ " vent hole in a No. 6 rubber stopper (suitable for the $3.8 \mathrm{~L}$ feed container). Position a $151 / 2$ " long $\mathrm{X} 1 / 4$ " diameter glass tube through the rubber stopper so that the end of the glass tube is $1^{\prime \prime}$ above the bottom of the feed container. For support, attach a piece of tape (as a flag) on the $0.51 \mathrm{~mm}$ feed line $15 "$ from the free end and insert the tubing through the glass dip tube.

Assembly confirmed: Date:

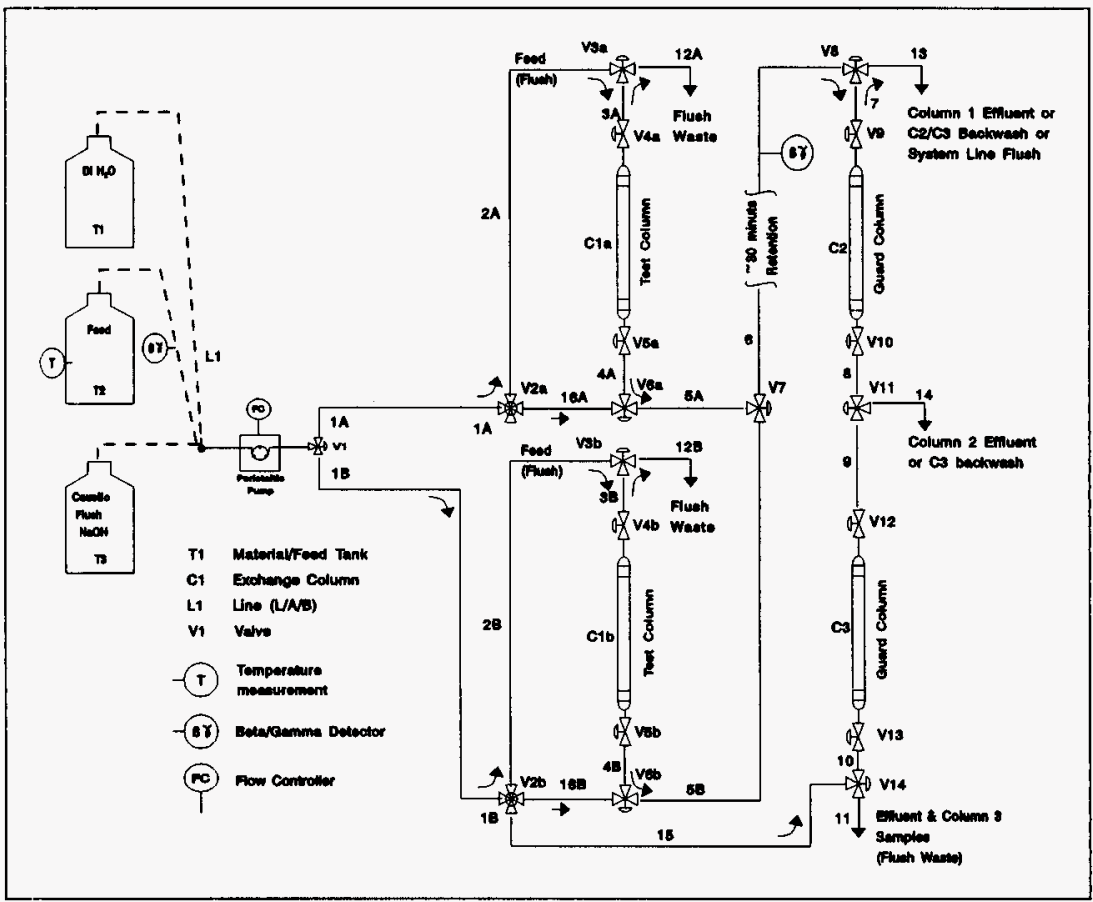

Figure A-1: Bench-Scale Cesium Exchange Flows and Instrumentation 
Sheet 1: Feed System Assembly - Continued

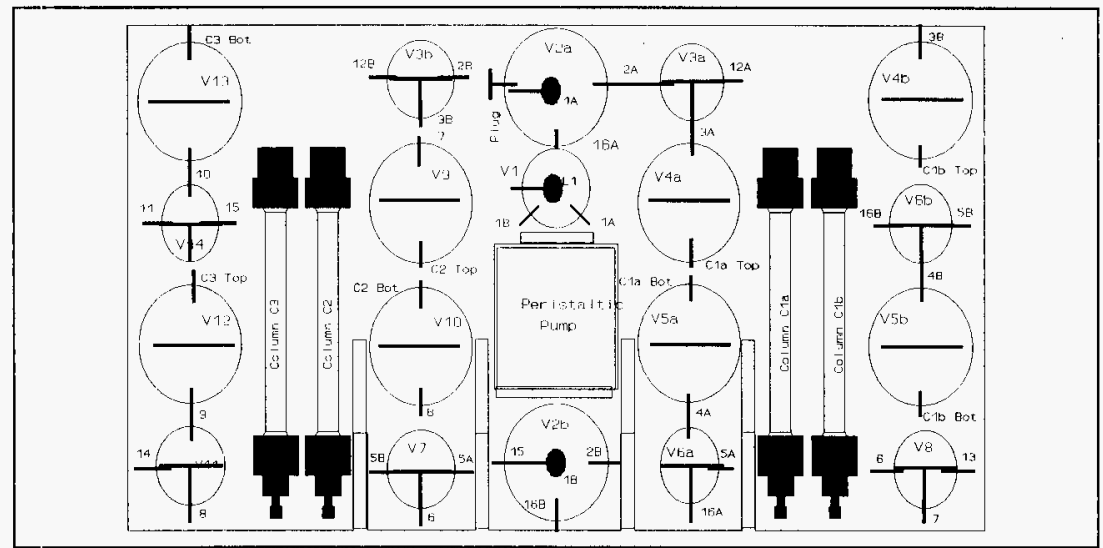

Figure A-2: Physical Test Assembly Valve and Column Arrangement 
Sheet 2: Test Assembly Instructions and Checksheet

Checksheet\#

Mount valves and columns in test assembly (See Figure A-1 for flow intent, Figure A-2 for layout).

Connect line $1 \mathrm{~A}\left(3.2 \mathrm{~mm}\right.$ ID, $\left.20 \mathrm{~cm} \mathrm{Tygon}{ }^{3}\right)$ to $\mathrm{V} 1$ and $\mathrm{V} 2 \mathrm{a}$.

Connect line $1 \mathrm{~B}$ (3.2 $\mathrm{mm}$ ID, $39 \mathrm{~cm}$ Tygon) to $\mathrm{V} 1$ and $\mathrm{V} 2 \mathrm{~b}$.

Connect line 2A (3.2 mm ID, $7 \mathrm{~cm}$ Tygon) to V2a and V3a.

Connect line 2B (3.2 mm ID, $44 \mathrm{~cm}$ Tygon) to V2b and V3b.

Connect line $3 \mathrm{~A}$ (3.2 $\mathrm{mm}$ ID, $5 \mathrm{~cm}$ Tygon) to $\mathrm{V} 3 \mathrm{a}$ and $\mathrm{V} 4 \mathrm{a}$.

Connect line $3 \mathrm{~B}$ ( $3.2 \mathrm{~mm} \mathrm{ID,} 43 \mathrm{~cm}$ Tygon) to V3b and V4b.

Connect line (Composite*) to $\mathrm{V} 4 \mathrm{a}$ and $\mathrm{Cla}$ (top).

Connect line (Composite) to V4b and Clb (top).

Connect line (Composite*) to C1a (bottom) and V5a.

Connect line (Composite*) to V5b and Clb (bottom).

Connect line 4A (3.2 mm ID, $5 \mathrm{~cm}$ Tygon) to V5a and V6a.

Connect line 4B (3.2 $\mathrm{mm}$ ID, $5 \mathrm{~cm}$ Tygon) to V5b and V6b.

Connect line $5 \mathrm{~A}(3.2 \mathrm{~mm}$ ID, $28 \mathrm{~cm}$ Tygon) to V6a and V7.

Connect line $5 \mathrm{~B}(3.2 \mathrm{~mm}$ ID, $71 \mathrm{~cm}$ Tygon) to V6b and V7.

Connect line 6 (V7 to the following composite: $3.2 \mathrm{~mm}$ ID, $2 \mathrm{~cm}$ Tygon joined to $4.8 \mathrm{~mm}$

ID, $60 \mathrm{~cm}$ Tygon joined to $3.2 \mathrm{~mm}$ ID, $25 \mathrm{~cm}$ Tygon to V8).

Connect line 7 (3.2 $\mathrm{mm} \mathrm{ID,} 71 \mathrm{~cm}$ Tygon) to V8 and V9.

Connect line (Composite*) to $\mathrm{V} 9$ and $\mathrm{C} 2$ (top).

Connect line (Composite ${ }^{*}$ ) to V10 and C2 (bottom).

Connect line 8 (3.2 mm ID, $32 \mathrm{~cm}$ Tygon) to $\mathrm{V} 10$ and $\mathrm{V} 11$

Connect line 9 (3.2 $\mathrm{mm}$ ID, $5 \mathrm{~cm}$ Tygon) to V11 and V12.

Connect line (Composite*) to V12 and C3 (top).

Connect line (Composite ${ }^{*}$ ) to V13 and C3 (bottom).

Connect line $10(3.2 \mathrm{~mm} \mathrm{ID,} 5 \mathrm{~cm}$ Tygon) to V13 and V14.

Connect line 15 (3.2 $\mathrm{mm}$ ID, $36 \mathrm{~cm}$ Tygon) to $\mathrm{V} 2 \mathrm{~b}$ and $\mathrm{V} 14$.

Connect line 12A (3.2 $\mathrm{mm} \mathrm{ID,} 60 \mathrm{~cm}$ Tygon) to V3a.

Connect line $13(3.2 \mathrm{~mm}$ ID, $25 \mathrm{~cm}$ Tygon) to V8

Connect line 14 (3.2 $\mathrm{mm}$ ID, $25 \mathrm{~cm}$ Tygon) to V11.

Connect line 11 (3.2 mm ID, $35 \mathrm{~cm}$ Tygon) to V14.

Connect line 12B (3.2 mm ID, $60 \mathrm{~cm}$ Tygon) to V3b.

Connect line 16A (3.2 mm ID, $35 \mathrm{~cm}$ Tygon) to V2a and V6a.

Connect line 16A (3.2 $\mathrm{mm}$ ID, $35 \mathrm{~cm}$ Tygon) to V2a and V6a.

Composite $^{*}=(3.2 \mathrm{~mm}$ ID, $2 \mathrm{~cm}$ Tygon, $3.2 \mathrm{~mm} \times 1.6 \mathrm{~mm}$ polypropylene connector, $1.6 \mathrm{~mm}$ ID. $2 \mathrm{~cm}$ Tygon, $1.6 \mathrm{~mm}$ ID, $79 \mathrm{~cm}$ Teflon).

Assembly confirmed (init.):

Date:

3 Tygon is a trademark of Norton Performance Plastics, Akron, $\mathrm{OH}$. 
Sheet 3: Pump Calibration for the CST Column Test

Otjective: To compare the pump flow rate at different locations in the test apparatus. The flow rate at $12 \mathrm{~A}$ will be plotted against effluent flow rates at lines 13,14 , and 11 . This will be repeated for the flow at $12 \mathrm{~B}$ and lines 13,14 , and 11 using $0.5 \mathrm{M} \mathrm{NaOH}$.

Begin by adjusting the pump dial to achieve the target flow rate of $0.27 \mathrm{~mL} / \mathrm{min}$ at line 11 . Follow the steps below to measure the flow rate. When this desired flow rate is reached, inscribe a mark on the pump dial and record approximate radial setting. This procedure will be carried out for two pump settings in the vicinity of the target. Turn pump knob counterclockwise half distance to zero flow, and repeat flow rate measurement. Then turn the pump knob clockwise until the same distance to the right of the inscribed set point is reached.

Executed for Test Procedure Step:

Checksheet\#

Executed by (print name):

Run Start (Date/time): Completed Date/time:

Prior to carrying out the procedure:

A. Place an empty $100 \mathrm{~mL}$ beaker on an analytical top loading balance for ease of continual weight measurements. With the aid of a laboratory stand secure discharge lines $12 \mathrm{~A}, 12 \mathrm{~B}, 13,14$, and 11 above this tared receiver.

B. Place line $\mathrm{L} 1$ into a feed bottle containing $300 \mathrm{~mL}$ of $0.5 \underline{\mathrm{M} \mathrm{NaOH}}$.

C. Set valve positions per Configuration 1 , for $\mathrm{Cla}$; all other valves shall remain closed.

D. Adjust the pump knob setting to an approximate $30^{\circ}$ radial position from zero. Once the system has been charged with the caustic solution, begin the test procedure.

\section{Test Procedure:}

1. Turn on pump for 20 minutes; use a stop watch.

2. Turn pump off, record time of flow, weigh the receiver.

3. Record all data in the table below.

4. With the same pump setting take flow rate measurements with valves positioned per Config. $2,3 \& 4$.

5. Repeat steps B thru 4 for valves positioned for flow through backup column Clb. 
Sheet 3: Pump Calibration for the CST Column Test - Continued

Config. 1: Full System Forward Feed Valving Configuration (Forward flow to Line 11)

\begin{tabular}{||c|c|c|c||}
\hline Valve & Direction & Valve & Direction \\
\hline \hline $\mathrm{V} 1$ & $\mathrm{~L} 1 \rightarrow \mathrm{V} 1 \rightarrow 1 \mathrm{~A} / \mathrm{B}$ & $\mathrm{V} 8$ & $6 \rightarrow \mathrm{V} 8 \rightarrow 7$ \\
\hline $\mathrm{V} 2 \mathrm{a} / \mathrm{b}$ & $1 \mathrm{~A} / \mathrm{B} \rightarrow \mathrm{V} 2 \mathrm{a} / \mathrm{b} \rightarrow 2 \mathrm{~A} / \mathrm{B}$ & $\mathrm{V} 9$ & $7 \rightarrow \mathrm{V} 9 \rightarrow \mathrm{C} 2$ \\
\hline $\mathrm{V} 3 \mathrm{a} / \mathrm{b}$ & $2 \mathrm{~A} / \mathrm{B} \rightarrow \mathrm{V} 3 \mathrm{a} / \mathrm{b} \rightarrow 3 \mathrm{~A} / \mathrm{B}$ & $\mathrm{V} 10$ & $\mathrm{C} 2 \rightarrow \mathrm{V} 10 \rightarrow 8$ \\
\hline $\mathrm{V} 4 \mathrm{a} / \mathrm{b}$ & $3 \mathrm{~A} / \mathrm{B} \rightarrow \mathrm{V} 4 \mathrm{a} / \mathrm{b} \rightarrow \mathrm{C} 1 \mathrm{a} / \mathrm{b}$ & $\mathrm{V} 11$ & $8 \rightarrow \mathrm{V} 11 \rightarrow 9$ \\
\hline $\mathrm{V} 5 \mathrm{a} / \mathrm{b}$ & $\mathrm{C} 1 \mathrm{a} / \mathrm{b} \rightarrow \mathrm{V} 5 \mathrm{a} / \mathrm{b} \rightarrow 4 \mathrm{~A} / \mathrm{B}$ & $\mathrm{V} 12$ & $9 \rightarrow \mathrm{V} 12 \rightarrow \mathrm{C} 3$ \\
\hline $\mathrm{V} 6 \mathrm{a} / \mathrm{b}$ & $4 \mathrm{~A} / \mathrm{B} \rightarrow \mathrm{V} 6 \mathrm{a} / \mathrm{b} \rightarrow 5 \mathrm{~A} / \mathrm{B}$ & $\mathrm{V} 13$ & $\mathrm{C} 3 \rightarrow \mathrm{V} 13 \rightarrow 10$ \\
\hline $\mathrm{V} 7$ & $5 \mathrm{~A} / \mathrm{B} \rightarrow \mathrm{V} 7 \rightarrow 6$ & $\mathrm{~V} 14$ & $10 \rightarrow \mathrm{V} 14 \rightarrow 11$ \\
\hline
\end{tabular}

Config. 2: First Guard Column Forward Feed Valving Configuration (Forward Flow to Line 14)

\begin{tabular}{|c|c|c|c|}
\hline Valve & Direction & Valve & Direction \\
\hline $\mathrm{V} 1$ & $\mathrm{~L} 1 \rightarrow \mathrm{V} 1 \rightarrow 1 \mathrm{~A} / \mathrm{B}$ & $\mathrm{V} 7$ & $5 \mathrm{~A} / \mathrm{B} \rightarrow \mathrm{V} 7 \rightarrow 6$ \\
\hline $\mathrm{V} 2 \mathrm{a} / \mathrm{b}$ & $1 \mathrm{~A} / \mathrm{B} \rightarrow \mathrm{V} 2 \mathrm{a} / \mathrm{b} \rightarrow 2 \mathrm{~A} / \mathrm{B}$ & $\mathrm{V} 8$ & $6 \rightarrow \mathrm{V} 8 \rightarrow 7$ \\
\hline $\mathrm{V} 3 \mathrm{a} / \mathrm{b}$ & $2 \mathrm{~A} / \mathrm{B} \rightarrow \mathrm{V} 3 \mathrm{a} / \mathrm{b} \rightarrow 3 \mathrm{~A} / \mathrm{B}$ & $\mathrm{V} 9$ & $7 \rightarrow \mathrm{V} 9 \rightarrow \mathrm{C} 2$ \\
\hline $\mathrm{V} 4 \mathrm{a} / \mathrm{b}$ & $3 \mathrm{~A} / \mathrm{B} \rightarrow \mathrm{V} 4 \mathrm{a} / \mathrm{b} \rightarrow \mathrm{C} 1 \mathrm{a} / \mathrm{b}$ & $\mathrm{V} 10$ & $\mathrm{C} 2 \rightarrow \mathrm{V} 10 \rightarrow 8$ \\
\hline $\mathrm{V} 5 \mathrm{a} / \mathrm{b}$ & $\mathrm{C} 1 \mathrm{a} / \mathrm{b} \rightarrow \mathrm{V} 5 \mathrm{a} / \mathrm{b} \rightarrow 4 \mathrm{~A} / \mathrm{B}$ & $\mathrm{V} 11$ & $8 \rightarrow \mathrm{V} 11 \rightarrow 14$ \\
\hline $\mathrm{V} 6 \mathrm{a} / \mathrm{b}$ & $4 \mathrm{~A} / \mathrm{B} \rightarrow \mathrm{V} 6 \mathrm{a} / \mathrm{b} \rightarrow 5 \mathrm{~A} / \mathrm{B}$ \\
\hline
\end{tabular}

Config.3: Lead Column Forward Feed Valving Configuration (Forward Flow to Line 13)

\begin{tabular}{|c|c|c|c||}
\hline Valve & Direction & Valve & Direction \\
\hline $\mathrm{V} 1$ & $\mathrm{~L} 1 \rightarrow \mathrm{V} 1 \rightarrow 1 \mathrm{~A} / \mathrm{B}$ & $\mathrm{V} 5 \mathrm{a} / \mathrm{b}$ & $\mathrm{C} 1 \mathrm{a} / \mathrm{b} \rightarrow \mathrm{V} 5 \mathrm{a} / \mathrm{b} \rightarrow 4 \mathrm{~A} / \mathrm{B}$ \\
\hline $\mathrm{V} 2 \mathrm{a} / \mathrm{b}$ & $1 \mathrm{~A} / \mathrm{B} \rightarrow \mathrm{V} 2 \mathrm{a} / \mathrm{b} \rightarrow 2 \mathrm{~A} / \mathrm{B}$ & $\mathrm{V} 6 \mathrm{a} / \mathrm{b}$ & $4 \mathrm{~A} / \mathrm{B} \rightarrow \mathrm{V} 6 \mathrm{a} / \mathrm{b} \rightarrow 5 \mathrm{~A} / \mathrm{B}$ \\
\hline $\mathrm{V} 3 \mathrm{a} / \mathrm{b}$ & $2 \mathrm{~A} / \mathrm{B} \rightarrow \mathrm{V} 3 \mathrm{a} / \mathrm{b} \rightarrow 3 \mathrm{~A} / \mathrm{B}$ & $\mathrm{V} 7$ & $5 \mathrm{~A} / \mathrm{B} \rightarrow \mathrm{V} 7 \rightarrow 6$ \\
\hline $\mathrm{V} 4 \mathrm{a} / \mathrm{b}$ & $3 \mathrm{~A} / \mathrm{B} \rightarrow \mathrm{V} 4 \mathrm{a} / \mathrm{b} \rightarrow \mathrm{Cla} / \mathrm{b}$ & $\mathrm{V} 8$ & $6 \rightarrow \mathrm{V} 8 \rightarrow 13$ \\
\hline
\end{tabular}

Config. 4: CST Pump Flow Rate Calibration Valve Configuration (Forward Flush bypass to Line 12A/B

\begin{tabular}{|c|c|}
\hline Valve & Direction \\
\hline \hline $\mathrm{V} 1$ & $\mathrm{~L} 1 \rightarrow \mathrm{V} 1 \rightarrow 1 \mathrm{~A} / \mathrm{B}$ \\
\hline $\mathrm{V} 2 \mathrm{a} / \mathrm{b}$ & $1 \mathrm{~A} / \mathrm{B} \rightarrow \mathrm{V} 2 \mathrm{a} / \mathrm{b} \rightarrow 2 \mathrm{~A} / \mathrm{B}$ \\
\hline $\mathrm{V} 3 \mathrm{a} / \mathrm{b}$ & $2 \mathrm{~A} / \mathrm{B} \rightarrow \mathrm{V} 3 \mathrm{a} / \mathrm{b} \rightarrow 12 \mathrm{~A} / \mathrm{B}$ \\
\hline
\end{tabular}


HNF-SD-RE-TPI-003, Rev. 0

\begin{tabular}{|c|c|c|c|c|c|c|c|c|c|}
\hline \multicolumn{6}{|c|}{ Sheet 3: Pump Calibration Flow Measurement } & \multicolumn{4}{|c|}{ Checksheet \# } \\
\hline \multicolumn{7}{|c|}{ Executed By: } & \multicolumn{3}{|c|}{ Pump Knob Position: _... } \\
\hline \multirow[t]{3}{*}{ Column } & \multirow{3}{*}{$\begin{array}{c}\text { Discharge } \\
\text { point } \\
\text { (Line \#) }\end{array}$} & \multicolumn{4}{|c|}{ Run 1} & \multicolumn{4}{|c|}{ Run 2} \\
\hline & & \multirow[t]{2}{*}{ Time } & \multicolumn{2}{|c|}{ Mass, g } & \multirow{2}{*}{$\begin{array}{c}\text { Rate } \\
\mathrm{mL} / \mathrm{min}\end{array}$} & \multirow[t]{2}{*}{ Time } & \multicolumn{2}{|c|}{ Mass, $\mathrm{g}$} & \multirow{2}{*}{$\begin{array}{l}\text { Rate } \\
\mathrm{mL} / \mathrm{min}\end{array}$} \\
\hline & & & Init & Final & & & Init. & Final & \\
\hline \multirow{4}{*}{ cla } & 11 & & & & & & & & \\
\hline & 14 & & & & & & & & \\
\hline & 13 & & & & & & & & \\
\hline & $12 \mathrm{~A}$ & & & & & & & & \\
\hline \multirow{4}{*}{ cib } & 11 & & & & & & & & \\
\hline & 14 & & & & & & & & \\
\hline & 13 & & & & & & & & \\
\hline & $12 \mathrm{~B}$ & & & & & & & & \\
\hline \multirow[t]{3}{*}{ Column } & \multirow{3}{*}{$\begin{array}{c}\text { Discharge } \\
\text { point } \\
\text { (Line \#) }\end{array}$} & \multicolumn{4}{|c|}{ Run 3} & \multirow{3}{*}{\multicolumn{4}{|c|}{ Avg tlow rate $\mathrm{ml} / \mathrm{min}$}} \\
\hline & & Time & & $\mathrm{s}, \mathrm{g}$ & Rate & & & & \\
\hline & & & Init. & Final & 111 & & & & \\
\hline \multirow{4}{*}{ cla } & 11 & & & & & & & & \\
\hline & 14 & & & & & & & & \\
\hline & 13 & & & & & & & & \\
\hline & $12 \mathrm{~A}$ & & & & & & & & \\
\hline \multirow{4}{*}{ clb } & 11 & & & & & & & & \\
\hline & 14 & & & & & & & & \\
\hline & 13 & & & & & & & & \\
\hline & $12 \mathrm{~B}$ & & & & & & & & \\
\hline
\end{tabular}


Sheet 4: Waste Feed Preparation

Objective: Prepare $5000 \mathrm{~mL}$ batch of waste feed for CST sorbent test.

Executed for Test Procedure Step: 4 4.2.3

Checksheet\#

Executed by (print name):

Date/time:

1. A composite $3.8 \mathrm{~L}$ feed vessel will be used in the test. The feed material will be prepared one liter at a time until five liters are ready to begin the test. One liter bottles will be available for storage of material $(>3.8 \mathrm{~L})$ until use. The following calculations are prepared for estimated as-received waste densities as Tabled below.

2. Remove saltcake from sample jars (per Table) to total approximately

$\frac{1000 \mathrm{~g} \mathrm{feed}}{1+(1 \mathrm{~g} \mathrm{saltcake}) \times \frac{(\mathrm{gNaOH}}{g \text { saltcake }}}=(\quad)$ sal tcake

Tare wt of 2L beaker:____ g F Feed Source: Tank

Gross wt. Beaker:_________ g

Net wt. salt:______ g

Record bottle \#s ___ copy to lab notebook

3. Add $\mathrm{NaOH}$, at concentration of Table, as:

$\frac{(1) \text { g NaOH }}{g \text { saltcake }} \times(\quad$ g saltcake $=(\quad$ ig NaOH

Gross wt. Beaker: g

Net wt. $\mathrm{NaOH}$ : $\mathrm{g}$

\begin{tabular}{|l|r|r|r|}
\hline Tank & $\begin{array}{c}\text { Salt Cake Density } \\
(\mathrm{g} / \mathrm{mL})\end{array}$ & $\begin{array}{c}\text { Diluent } \mathrm{NaOH} \\
(\mathrm{Mol} / \mathrm{L})\end{array}$ & $\begin{array}{c}\text { Diluent } \mathrm{NaOH} \\
(\mathrm{g} / \mathrm{g} \text { saltcake })\end{array}$ \\
\hline $241-\mathrm{U}-108$ & 1.74 & 0.636 & 2.1579 \\
\hline $241-\mathrm{U}-109$ & 1.75 & 0.676 & 1.6609 \\
\hline $241-\mathrm{A}-101$ & 1.70 & 0.694 & 1.5589 \\
\hline $241-\mathrm{BY}-110$ & 1.44 & 0.718 & 1.6394 \\
\hline $241-\mathrm{S}-102$ & 1.64 & 0.749 & 1.2614 \\
\hline
\end{tabular}

4. Mix on magnetic stirring plate until no crystals are visible. Minimize heating during dissolution. 
Sheet 4: Waste Feed Preparation - Continued.

HNF-SD-RE-TPI-003, Rev. 0 Checksheet\#

5. Allow to settle, decant clear liquor into feed tank $\mathrm{T} 2$, if solids are present then go to either step 6 or 7 before decanting into the $3.8 \mathrm{~L}$ vessel.

6. If solids do not settle out, do the following:

6a. Tare centrifuge cones.

6b. Centrifuge the waste material mixture, and decant clear liquid into feed tank T2.

6c. At completion, weigh all centrifuge cones to determine the accumulated solids mass.

\begin{tabular}{||l|l|l|l||}
\hline \hline Cone & Tare $(\mathrm{g})$ & Gross $(\mathrm{g})$ & Net $(\mathrm{g})$ \\
\hline & & & \\
\hline & & & \\
\hline & & & \\
\hline & & & \\
\hline & & & \\
\hline
\end{tabular}

Total solids: g. Place solids into $250 \mathrm{~mL}$ vial labeled "Saltcake

Solids". Bypass Step 7.

7. If solids are present and settle out, then decant the liquid very carefully into the $3.8 \mathrm{~L}$ vessel taking care to minimize the amount of liquid left over. Transfer the solids into a $250 \mathrm{~mL}$ vial labeled "Saltcake Solids".

Tare wt. of "Saltcake Solids" = g.

Repeat steps 2 thru 7 for each $1 \mathrm{~kg}$ batch. In the lab notebook record observations of liquor clarity, color and any suspended solids.

8. Upon completion of waste material addition to $\mathrm{T} 2$, pipette a $15 \mathrm{~mL}$ aliquot into prelabeled sample vials CF1 \& CF2 (later batches for tanks as CF3 et seq.).

9. Take an additional aliquot from $\mathrm{T} 2$, measure and record density as:

$\frac{(\mid) \text { g Sample }-(1) \text { g Tare }}{\text { ) mL Sample }}=(\quad) \frac{\text { g Feed }}{m L}$

10. Dry contents of "Saltcake Solids". Gross Wt. Net Wt.

Place two samples of separated solids in prelabeled sample vials CFS1 and CFS2 (later batches for tanks as CFS3 et. seq.) 
Sheet 5: Pump Flow Rate Set and Measurement

Executed for Test Procedure Step: ___.2.4 Checksheet\#

Executed by:

Däte/time:

Target Flow Rate: $\mathrm{g} / \mathrm{hr}$

Receiver/bottle tare: grams

Feed Material:

Density $\mathrm{g} / \mathrm{mL}$

Place Effluent Line (12A/B) into receiver and Feed Line (L1) into Feed Tank.

Valve Placement/Confirmation (See Figure A-1) other valves closed:

Config. 4: CST Pump Flow Rate Calibration Valve Configuration (Foward flush bypass to Line 12A/B)

\begin{tabular}{|c|c|}
\hline Valve & Direction \\
\hline \hline $\mathrm{V} 1$ & $\mathrm{~L} 1 \rightarrow \mathrm{V} 1 \rightarrow 1 \mathrm{~A} / \mathrm{B}$ \\
\hline $\mathrm{V} 2 \mathrm{a} / \mathrm{b}$ & $1 \mathrm{~A} / \mathrm{B} \rightarrow \mathrm{V} 2 \mathrm{a} / \mathrm{b} \rightarrow 2 \mathrm{~A} / \mathrm{B}$ \\
\hline $\mathrm{V} 3 \mathrm{a} / \mathrm{b}$ & $2 \mathrm{~A} / \mathrm{B} \rightarrow \mathrm{V} 3 \mathrm{a} / \mathrm{b} \rightarrow 12 \mathrm{~A} / \mathrm{B}$ \\
\hline
\end{tabular}

\begin{tabular}{|c|c|c|c|c|c|c|c|c|c|}
\hline \multirow{2}{*}{$\begin{array}{l}\text { Time } \\
(\min )\end{array}$} & \multicolumn{3}{|c|}{ Mass (g) } & \multirow{2}{*}{$\begin{array}{l}\text { Flow } \\
(\mathrm{g} / \mathrm{hr})\end{array}$} & \multirow{2}{*}{$\begin{array}{l}\text { Time } \\
\text { (min) }\end{array}$} & \multicolumn{3}{|c|}{ Mass (g) } & \multirow{2}{*}{$\begin{array}{l}\text { Flow } \\
(\mathrm{g} / \mathrm{hr})\end{array}$} \\
\hline & Tare & Gross & Net & & & Tare & Gross & Net & \\
\hline & & & & & & & & & \\
\hline & & & & & & & & & \\
\hline & & & & & & & & & \\
\hline & & & & & & & & & \\
\hline & & & & & & & & & \\
\hline & & & & & & & & & \\
\hline & & & & & & & & & \\
\hline
\end{tabular}

Flow Rate $=$ Average of last three test periods without pump setting change

Flow Rate $=$ $\mathrm{g} / \mathrm{hr}=$ $\mathrm{mL} / \mathrm{hr}$

Get Regression Curve from Sheet 3 Performance for Configuration 1 relative to Configuration 4.

Full System Flow: $\mathrm{mL} / \mathrm{hr}$ 
Sheet 6: Effluent Collection Record

Executed for Test Procedure Step:

Checksheet\#

Executed by:

Date/time:

Receiver/bottle tare: grams

Feed Line (L1) into Feed Tank: Primary Column:

Feed Material:

Density $\mathrm{g} / \mathrm{mL}$

Effluent Line (11) into

Valve Placement/Confirmation (See Figure A-1, other valves closed):

Config.1: Full System Forward Feed Valving Configuration (Forward flow to Line 11)

\begin{tabular}{|c|c|c|c||}
\hline Valve & Direction & Valve & Direction \\
\hline \hline $\mathrm{V} 1$ & $\mathrm{~L} 1 \rightarrow \mathrm{V} 1 \rightarrow \mathrm{lA} / \mathrm{B}$ & $\mathrm{V} 8$ & $6 \rightarrow \mathrm{V} 8 \rightarrow 7$ \\
\hline $\mathrm{V} 2 \mathrm{a} / \mathrm{b}$ & $1 \mathrm{~A} / \mathrm{B} \rightarrow \mathrm{V} 2 \mathrm{a} / \mathrm{b} \rightarrow 2 \mathrm{~A} / \mathrm{B}$ & $\mathrm{V} 9$ & $7 \rightarrow \mathrm{V} 9 \rightarrow \mathrm{C} 2$ \\
\hline $\mathrm{V} 3 \mathrm{a} / \mathrm{b}$ & $2 \mathrm{~A} / \mathrm{B} \rightarrow \mathrm{V} 3 \mathrm{a} / \mathrm{b} \rightarrow 3 \mathrm{~A} / \mathrm{B}$ & $\mathrm{V} 10$ & $\mathrm{C} 2 \rightarrow \mathrm{V} 10 \rightarrow 8$ \\
\hline $\mathrm{V} 4 \mathrm{a} / \mathrm{b}$ & $3 \mathrm{~A} / \mathrm{B} \rightarrow \mathrm{V} 4 \mathrm{a} / \mathrm{b} \rightarrow \mathrm{C} 1 \mathrm{a}$ & $\mathrm{V} 11$ & $8 \rightarrow \mathrm{V} 11 \rightarrow 9$ \\
\hline $\mathrm{V} 5 \mathrm{a} / \mathrm{b}$ & $\mathrm{C} 1 \mathrm{a} / \mathrm{b} \rightarrow \mathrm{V} 5 \mathrm{a} / \mathrm{b} \rightarrow 4 \mathrm{~A} / \mathrm{B}$ & $\mathrm{V} 12$ & $9 \rightarrow \mathrm{V} 12 \rightarrow \mathrm{C} 3$ \\
\hline $\mathrm{V} 6 \mathrm{a} / \mathrm{b}$ & $4 \mathrm{~A} / \mathrm{B} \rightarrow \mathrm{V} 6 \mathrm{a} / \mathrm{b} \rightarrow 5 \mathrm{~A} / \mathrm{B}$ & $\mathrm{V} 13$ & $\mathrm{C} 3 \rightarrow \mathrm{V} 13 \rightarrow 10$ \\
\hline $\mathrm{V} 7$ & $5 \mathrm{~A} / \mathrm{B} \rightarrow \mathrm{V} 7 \rightarrow 6$ & $\mathrm{~V} 14$ & $10 \rightarrow \mathrm{V} 14 \rightarrow 11$ \\
\hline
\end{tabular}

Flow Rate (from Sheet 5, Checksheet \#__ ): $\mathrm{mL} / \mathrm{hr}$

Puimp On: (time/date)

Observations:

Pump Off: (time/date)

Mass Collected (gross receiver): g (net collected):

( $U_{i s e}$ additional sheets for mass collection if collection vessel is changed) g 
HNF-SD-RE-TPI-003, Rev. 0

Sheet 7: Primary Column Sampling

Executed for Test Procedure Step:

Checksheet\#

Executed by:

Completed Date/time:

Runtime

Feed Line (L1) into Feed Tank:

Primary Column:

Feed Material:

Sp. gravity (from Sheet 4):

Sample Vial plus stopper Tare weight: g

Place effluent Line (13) into Flush Vial.

Change V8 position: $\quad$ from: $6 \rightarrow \mathrm{V} 8 \rightarrow 7 \quad$ to: $6 \rightarrow \mathrm{V} 8 \rightarrow 13$

Flow Rate (from Sheet 5, Checksheet\#

): $\mathrm{mL} / \mathrm{hr}$

Collect $\sim 2 \mathrm{~mL}$ in Flush Vial (approx. $8 \mathrm{~min}$ ); Start (Runtime)

Place line 13 into sample vial

End (Runtime)

Collect $\sim 5 \mathrm{~mL}$ in sample vial (approx. $19 \mathrm{~min}$ ) Start (Runtime)

Time of collection: End (Runtime) $\min$ $\mathrm{sec}$

Redirect valve V8 back to line 7 as follows:

Change V8 position: $\quad$ from: $6 \rightarrow V 8 \rightarrow 13$ to: $6 \rightarrow V 8 \rightarrow 7$

Weight Sample + stopper: g, Net Sample: g

Flow rate $=$ Net Sample / sample time $=$ $\mathrm{g} / \mathrm{hr}$ $\mathrm{g} / \mathrm{hr} /$ density $=$ $\mathrm{mL} / \mathrm{hr}$

Observations: 
Executed for Test Procedure Step: 4 4.2.5.2

Executed by:

Completed Date/time:

Run Start (Date/time):

\begin{tabular}{|c|c|c|c|c|c|}
\hline Sample & Projected Run Time & $\begin{array}{l}\text { Projected } \\
\text { Clock Time }\end{array}$ & $\begin{array}{c}\text { Actual Clock } \\
\text { Time }\end{array}$ & On-Line $x-\gamma$ & Feed Temp. $\left({ }^{\circ} \mathrm{C}\right)$ \\
\hline SC1E-1 & $1 \mathrm{hr} 0 \mathrm{~min}$ & & & & \\
\hline SC1E-2 & $17 \mathrm{hr} 40 \mathrm{~min}$ & & & & \\
\hline SC1E-3 & $34 \mathrm{hr} 20 \mathrm{~min}$ & & & & \\
\hline$S C 1 E-4$ & $51 \mathrm{hr} 0 \mathrm{~min}$ & & & & \\
\hline SC1E-5 & $67 \mathrm{hr} 40 \mathrm{~min}$ & & & & \\
\hline $\mathrm{SC} 1 \mathrm{E}-6$ & 84 hr $20 \mathrm{~min}$ & & & & \\
\hline SC $1 E-7$ & $101 \mathrm{hr} 0 \mathrm{~min}$ & & & & \\
\hline SC1E-8 & $117 \mathrm{hr} 40 \mathrm{~min}$ & & & & \\
\hline SC1E-9 & $134 \mathrm{hr} 20 \mathrm{~min}$ & & & & \\
\hline SC1E-10 & $151 \mathrm{hr} 0 \mathrm{~min}$ & & & & \\
\hline SC $1 E-11$ & $167 \mathrm{hr} 40 \mathrm{~min}$ & & & & \\
\hline$S C\lfloor E-12$ & $184 \mathrm{hr} 20 \mathrm{~min}$ & & & & \\
\hline$S C 1 E-13$ & $201 \mathrm{hr} 0 \mathrm{~min}$ & & & & \\
\hline SC IE-14 & $217 \mathrm{hr} 40 \mathrm{~min}$ & & & & \\
\hline $\mathrm{SC} 1 \mathrm{E}-15$ & $234 \mathrm{hr} 20 \mathrm{~min}$ & & & & \\
\hline SC1E-16 & $251 \mathrm{hr} 0 \mathrm{~min}$ & & & & \\
\hline $\mathrm{SC} 1 \mathrm{E}-17$ & $267 \mathrm{hr} 40 \mathrm{~min}$ & & & & \\
\hline SC $1 \mathrm{E}-18$ & $284 \mathrm{hr} 20 \mathrm{~min}$ & & & & \\
\hline SC1E-19 & $301 \mathrm{hr} 0 \mathrm{~min}$ & & & & \\
\hline SC1E-20 & $317 \mathrm{hr} 40 \mathrm{~min}$ & & & & \\
\hline SCIE-21 & $334 \mathrm{hr} 20 \mathrm{~min}$ & & & & \\
\hline SC1E-22 & $351 \mathrm{hr} 0 \mathrm{~min}$ & & & & \\
\hline SC1E-23 & $367 \mathrm{hr} 40 \mathrm{~min}$ & & & & \\
\hline SC1E-24 & $384 \mathrm{hr} 20 \mathrm{~min}$ & & & & \\
\hline SC1E-25 & $401 \mathrm{hr} 0 \mathrm{~min}$ & & & & \\
\hline
\end{tabular}


Sheet 8: Primary Column Sample Record - continued

HNF-SD-RE-TPI-003, Rev. 0 Checksheet\#

\begin{tabular}{|c|c|c|c|c|c|}
\hline Sample & Projected Run Time & $\begin{array}{c}\text { Projected } \\
\text { Clock Time }\end{array}$ & $\begin{array}{c}\text { Actual Clock } \\
\text { Time }\end{array}$ & On-Line $\not<-\gamma$ & Feed Temp. $\left({ }^{\circ} \mathrm{C}\right)$ \\
\hline $\mathrm{SC} 1 \mathrm{E}-26$ & $417 \mathrm{hr} 40 \mathrm{~min}$ & & & & \\
\hline $\mathrm{SC} 1 \mathrm{E}-27$ & $434 \mathrm{hr} 20 \mathrm{~min}$ & & & & \\
\hline SC1E-28 & $451 \mathrm{hr} 0 \mathrm{~min}$ & & & & \\
\hline SC $1 E-29$ & $467 \mathrm{hr} 40 \mathrm{~min}$ & & & & \\
\hline SC1E-30 & $484 \mathrm{hr} 20 \mathrm{~min}$ & & & & \\
\hline SC1E-31 & $501 \mathrm{hr} 0 \mathrm{~min}$ & & & & \\
\hline $\mathrm{SC} 1 \mathrm{E}-32$ & $517 \mathrm{hr} 40 \mathrm{~min}$ & & & & \\
\hline SCIE-33 & $534 \mathrm{hr} 20 \mathrm{~min}$ & & & & \\
\hline $\mathrm{SC} 1 \mathrm{E}-34$ & $551 \mathrm{hr} 0 \mathrm{~min}$ & & & & \\
\hline SC.1E-35 & $567 \mathrm{hr} 40 \mathrm{~min}$ & & & & \\
\hline SCIE-36 & $584 \mathrm{hr} 20 \mathrm{~min}$ & & & & \\
\hline SC $1 \mathrm{E}-37$ & $601 \mathrm{hr} \quad 0 \mathrm{~min}$ & & & & \\
\hline SC1E-38 & $617 \mathrm{hr} 40 \mathrm{~min}$ & & & & \\
\hline SC1E-39 & $634 \mathrm{hr} 20 \mathrm{~min}$ & & & & \\
\hline $\mathrm{SC} 1 \mathrm{E}-40$ & $651 \mathrm{hr} 0 \mathrm{~min}$ & & & & \\
\hline SC1E-41 & $667 \mathrm{hr} 40 \mathrm{~min}$ & & & & \\
\hline SC1E-42 & $684 \mathrm{hr} 20 \mathrm{~min}$ & & & & \\
\hline
\end{tabular}


Sheet 9: Secondary (C2) Column Sampling

Executed for Test Procedure Step: 4.2.5.3

Checksheet\#

Executed by:

Completed Date/time:

Feed Line (L1) into Feed Tank:

Feed Material: Sp. gravity (from Sheet 4):

Sample Vial plus stopper Tare weight: g

Effluent Line (14) into _Flush Vial_

Change V11 position: from: $8 \rightarrow \mathrm{V} 11 \rightarrow 9$ to: $8 \rightarrow \mathrm{V} 11 \rightarrow 14$

Flow Rate (from Sheet 4, Checksheet\# ): $\mathrm{g} / \mathrm{hr}$

Collect $\sim 2 \mathrm{~mL}$ in Flush Vial (approx. $8 \mathrm{~min}$ ); $\quad$ Start (Runtime)

End (Runtime)

Place line 14 into sample vial

Collect $\sim 5 \mathrm{~mL}$ in sample vial (approx. $19 \mathrm{~min}$ ); Start (Runtime) End (Runtime)

Time of collection: $\min$ $\mathrm{sec}$

Redirect valve V11 back to line 9

Change V11 position: $\quad$ from: $8 \rightarrow \mathrm{V} 11 \rightarrow 14$ to: $8 \rightarrow \mathrm{V} 11 \rightarrow 9$

Weight Sample + stopper: g, Net Sample: g

Flow rate $=$ Net Sample / sample time $=$ $\mathrm{g} / \mathrm{hr}$ $\mathrm{g} / \mathrm{hr} /$ density $=$ $\mathrm{mL} / \mathrm{hr}$

Observations: 
HNF-SD-RE-TPI-003, Rev. 0

Sheet 10: Secondary (C2) Column Sample Record

Executed for Test Procedure Step: 4 4 2.5.3

Executed by:

Checksheet\#

Date/time:

Run Start (Date/time):

\begin{tabular}{|c|c|c|c|c|c|}
\hline Sample & Projected Run Time & $\begin{array}{l}\text { Projected } \\
\text { Clock Time }\end{array}$ & $\begin{array}{l}\text { Actual Clock } \\
\text { Time }\end{array}$ & On-Line $\beta-\gamma$ & Feed Temp. $\left({ }^{\circ} \mathrm{C}\right)$ \\
\hline SC2E-1 & $17 \mathrm{hr} 10 \mathrm{~min}$ & & & & \\
\hline SC2E-2 & $50 \mathrm{hr} 30 \mathrm{~min}$ & & & & \\
\hline SC2E-3 & 83 hг $50 \mathrm{~min}$ & & & & \\
\hline $\mathrm{SC} 2 \mathrm{E}-4$ & $117 \mathrm{hr} 10 \mathrm{~min}$ & & & & \\
\hline $\mathrm{SC} 2 \mathrm{E}-5$ & $150 \mathrm{hr} 30 \mathrm{~min}$ & & & & \\
\hline SC2E-6 & $183 \mathrm{hr} 50 \mathrm{~min}$ & & & & \\
\hline $\mathrm{SC} 2 \mathrm{E}-7$ & $217 \mathrm{hr} 10 \mathrm{~min}$ & & & & \\
\hline SC2E-8 & $250 \mathrm{hr} 30 \mathrm{~min}$ & & & & \\
\hline SC2E-9 & 283 hг $50 \mathrm{~min}$ & & & & \\
\hline $\mathrm{SC} 2 \mathrm{E}-10$ & $317 \mathrm{hr} 10 \mathrm{~min}$ & & & & \\
\hline $\mathrm{SC} 2 \mathrm{E}-11$ & $350 \mathrm{hr} 30 \mathrm{~min}$ & & & & \\
\hline SC2E-12 & $383 \mathrm{hr} 50 \mathrm{~min}$ & & & & \\
\hline $\mathrm{SC} 2 \mathrm{E}-13$ & $417 \mathrm{hr} 10 \mathrm{~min}$ & & & & \\
\hline $\mathrm{SC} 2 \mathrm{E}-14$ & $450 \mathrm{hr} 30 \mathrm{~min}$ & & & & \\
\hline $\mathrm{SC} 2 \mathrm{E}-15$ & $483 \mathrm{hr} 50 \mathrm{~min}$ & & & & \\
\hline$S C 2 E-16$ & $517 \mathrm{hr} 10 \mathrm{~min}$ & & & & \\
\hline $\mathrm{SC} 2 \mathrm{E}-17$ & $550 \mathrm{hr} 30 \mathrm{~min}$ & & & & \\
\hline SC2E-18 & $583 \mathrm{hr} 50 \mathrm{~min}$ & & & & \\
\hline SC2E-19 & $617 \mathrm{hr} \quad 10 \mathrm{~min}$ & & & & \\
\hline $\mathrm{SC} 2 \mathrm{E}-20$ & $650 \mathrm{hr} 30 \mathrm{~min}$ & & & & \\
\hline SC2E-21 & $683 \mathrm{hr} 50 \mathrm{~min}$ & & & & \\
\hline
\end{tabular}


HNF-SD-RE-TPI-003, Rev. 0

Sheet 11: Primary Column Cla/b Reverse Feed Valving

Executed for Test Procedure Step:

Checksheet\#

Executed by:

Date/time:

Receiver/bottle tare: grams

Feed Line (LI) into Feed Tank \#

Feed Material:

Density $\mathrm{g} / \mathrm{mL}$

Effluent Line (12 A/B, Configuration 5) into

Valve Placement/Confirmation (See Figure A-1) for Configuration 5, other valves closed:

Config. 5: Column Cla/b Reverse Flush Valving Configuration (Reverse flush to Line 12A/B)

\begin{tabular}{|c|c|c|c||}
\hline \hline Valve & Direction & Valve & Direction \\
\hline \hline $\mathrm{V} 1$ & $\mathrm{~L} 1 \rightarrow \mathrm{V} 1 \rightarrow 1 \mathrm{~A} / \mathrm{B}$ & $\mathrm{V} 5 \mathrm{~A} / \mathrm{B}$ & $4 \mathrm{~A} / \mathrm{B} \rightarrow \mathrm{V} 5 \mathrm{~A} / \mathrm{B} \rightarrow \mathrm{C} 1 \mathrm{~A} / \mathrm{B}$ \\
\hline $\mathrm{V} 2 \mathrm{~A} / \mathrm{B}$ & $1 \mathrm{~A} / \mathrm{B} \rightarrow \mathrm{V} 2 \mathrm{~A} / \mathrm{B} \rightarrow 16 \mathrm{~A} / \mathrm{B}$ & $\mathrm{V} 4 \mathrm{~A} / \mathrm{B}$ & $\mathrm{C} 1 \mathrm{~A} / \mathrm{B} \rightarrow \mathrm{V} 4 \mathrm{~A} / \mathrm{B} \rightarrow 3 \mathrm{~A} / \mathrm{B}$ \\
\hline $\mathrm{V} 6 \mathrm{~A} / \mathrm{B}$ & $16 \mathrm{~A} / \mathrm{B} \rightarrow \mathrm{V} 6 \mathrm{~A} / \mathrm{B} \rightarrow 4 \mathrm{~A} / \mathrm{B}$ & $\mathrm{V} 3 \mathrm{~A} / \mathrm{B}$ & $3 \mathrm{~A} / \mathrm{B} \rightarrow \mathrm{V} 3 \mathrm{~A} / \mathrm{B} \rightarrow 12 \mathrm{~A} / \mathrm{B}$ \\
\hline
\end{tabular}

Pump On: (time/date); Runtime

Otiservations:

Punp Off: (time/date); Runtime

Mass Collected (gross receiver): g (net collected): (Use additional sheets for mass collection if collection vessel changed) 
HNF-SD-RE-TPI-003, Rev. 0

Sheet 12: Guard Columns C2 \& C3 Reverse Feed Valving

Executed for Test Procedure Step:

Checksheet\#

Executed by:

Date/time:

Receiver/bottle tare: grams

Feed Line (L1) into Feed Tank \#

Feed Material:

Density $\mathrm{g} / \mathrm{mL}$

Ef.lluent Line (13, Configuration 6) into

Valve Placement/Confirmation (See Figure A-1) for Configuration 6, other valves closed:

Config. 6: Reverse Feed Valving Configuration

(Reverse flush through guard columns)

\begin{tabular}{|c|c|c|c|}
\hline Valve & Direction & Valve & Direction \\
\hline $\mathrm{V} 1$ & $\mathrm{~L} 1 \rightarrow \mathrm{V} 1 \rightarrow 1 \mathrm{~B}$ & $\mathrm{~V} 11$ & $9 \rightarrow \mathrm{V} 11 \rightarrow 8$ \\
\hline $\mathrm{V} 2 \mathrm{~b}$ & $1 \mathrm{~B} \rightarrow \mathrm{V} 2 \mathrm{~b} \rightarrow 15$ & $\mathrm{~V} 10$ & $8 \rightarrow \mathrm{V} 10 \rightarrow \mathrm{C} 2$ \\
\hline $\mathrm{V} 14$ & $15 \rightarrow \mathrm{V} 14 \rightarrow 10$ & $\mathrm{~V} 9$ & $\mathrm{C} 2 \rightarrow \mathrm{V} 9 \rightarrow 7$ \\
\hline $\mathrm{V} 13$ & $10 \rightarrow \mathrm{V} 13 \rightarrow \mathrm{C} 3$ & $\mathrm{~V} 8$ & $7 \rightarrow \mathrm{V} 8 \rightarrow 13$ \\
\hline $\mathrm{V} 12$ & $\mathrm{C} 3 \rightarrow \mathrm{V} 12 \rightarrow 9$ & & \\
\hline
\end{tabular}

Pump On: (time/date)

Otservations:

Pump Off: (time/date)

Mass Collected (gross receiver): g (net collected): (U:ie additional sheets for mass collection if collection vessel is changed) g 


\section{Sheet 13: CST Sorbent Dissolution}

Objective: To remove and dissolve the CST sorbent at the end of the test. This procedure will facilitate waste disposal.

Sorbent Dissolution Procedure: Checksheet\#

NOTE: The CST sorbent will not be analyzed and will be dissolved in a batch.

1. Confirm the following valve positions:

Cla V4a \& V5a Closed

$\mathrm{Clb}$ V4b \& V5b Closed

C2 V9 \& V10 Closed

C3 V12 \& V13 Closed

2. Crimp the tubing to inhibit leaks, two crimps approximately 1 " apart on each side of the column.

3. Remove column Cla from the retainers.

4. Cut the line between the crimps above and below the column.

5. Remove the top of the column.

6. Deposit the sorbent into a 2 liter beaker by scraping and rinsing. The beaker will be large enough to hold all the CST sorbent ( $\sim 21$ grams) plus the required volume to dissolve the sorbent as indicated in Step 8.

7. Repeat the Steps 3 through 6 for columns C1b, C2, and C3.

8. Digest the sorbent by sequentially adding:

$610 \mathrm{~mL}$ DI water

$210 \mathrm{~mL}$ of $2 \underline{\mathrm{M}} \mathrm{HCL}$

$105 \mathrm{~mL}$ of $1 \underline{\mathrm{M}} \mathrm{HF}$

9. Place on a hot plate with a magnetic stirrer. Heat gently until the CST sorbent is dissolved.

10. Pour cooled solution into waste receiver labeled through hot cell drain.

pending disposal 
HNF-SD-RE-TPI-003, Rev. 0

Sheet 14: CST Sorbent Bed Density Determination

Objective: To determine the mass to volume ratio of the conditioned CST sorbent.

Procedure:

Checksheet\#

1. Dry approximately 100 grams of sorbent in a tared evaporating dish at $103^{\circ} \mathrm{C}$ for 4 hours.

2. Cool in a desiccator and weigh on an analytical balance to find per cent moisture.

Weight of the sorbent + evap dish: g

Weight of the evaporating dish: g

Weight of the CST Sorbent: g

3. Mix approximately 50 grams of the sorbent with $18 \mathrm{Mohm} \cdot \mathrm{cm}$ water and slurry the sorbent into each of the glass columns to approximately $50 \%$ of the column volume.

4. Condition the sorbent as follows (per instructions from the manufacturer):

a. Backflush the column with a high superficial velocity to backwash fines from the bed (usually $200 \%$ of the initial height of the bed). When evidence of fines ceases in the effluent, stop the flow of water and allow the bed to settle.

b. Using $0.5 \mathrm{M} \mathrm{NaOH}$, condition the bed in a downflow manner. Monitor the $\mathrm{pH}$ of the bed and when the effluent remains at a $\mathrm{pH}$ equal to or slightly greater than the $\mathrm{pH}$ of the waste feed $(\mathrm{pH} \approx 13.3)$. Check the $\mathrm{pH}$ in the effluent. When the $\mathrm{pH}$ value stabilizes, turn off the pump, allow the bed to settle. After settling, mark the top of the bed. Remove the sorbent from the column and determine the volume $(\mathrm{mL})$ that the bed occupied.

c. Wash the sorbent with $18 \mathrm{Mohm} \cdot \mathrm{cm}$ water until the $\mathrm{NaOH}$ has been flushed from the system. Analytically transfer the sorbent to a tared evaporating dish, washing all the sorbent from the column. Dry the sorbent overnight at $103^{\circ} \mathrm{C}$ and determine the dry mass of the sorbent. 
Sheet 14: CST Sorbent Bed Density Determination - cont'd. Checksheet\#

d. Repeat this for five iterations and use the average

\begin{tabular}{||l|l|l|l|l|l|l||}
\hline \hline Sample & $\begin{array}{l}\text { Settled Bed } \\
\text { Volume, } \mathrm{mL}\end{array}$ & $\begin{array}{l}\text { Wt. of Evap } \\
\text { Dish, g }\end{array}$ & $\begin{array}{l}\text { Dry Wt of } \\
\text { (Sorbent + Evap } \\
\text { Dish) g }\end{array}$ & $\begin{array}{l}\text { Net } \\
\text { Sorbent } \\
\text { Wt. g }\end{array}$ & $\begin{array}{l}\text { Density (dry g } \\
\text { /mL bed) }\end{array}$ & $\begin{array}{l}\text { Avg. } \\
\text { Density, } \\
\mathrm{g} / \mathrm{mL} \text { bed }\end{array}$ \\
\hline 1 & & & & & & \\
\hline 2 & & & & & & \\
\hline 5 & & & & & & \\
\hline 5 & & & & & & \\
\hline 5
\end{tabular}

\section{Bulk Density Measurements:}

Take a graduated cylinder $(25 \mathrm{~mL})$ and tare on a top loading balance. Using the other half of the sorbent from step 2, pour into the cylinder and tap the side to settle the sorbent. Record the weight of the cylinder and sorbent on the chart below. Using tongs to handle the cylinder, record the level of the sorbent in $\mathrm{mL}$. Repeat this operation for five iterations and use the average for the density.

\begin{tabular}{||c|c|c|c||}
\hline $\begin{array}{c}\text { Weight of cylinder } \\
\text { plus sorbent }\end{array}$ & $\begin{array}{c}\text { Weight of } \\
\text { cylinder }\end{array}$ & $\begin{array}{c}\text { Weight of } \\
\text { sorbent }\end{array}$ & $\begin{array}{c}\text { mL of sorbent } \\
\text { in cylinder }\end{array}$ \\
\hline & & & \\
\hline & & & \\
\hline & & & \\
\hline
\end{tabular}

Average Weight of Sorbent

Average $\mathrm{mL}$ of Sorbent

Density
$=$

$=$

$=$ $\mathrm{g} / \mathrm{mL}$ 


\section{Sheet 15: NaOH Solution Preparation from 5.0 mole/L Stock}

Objective: $\mathrm{NaOH}$ solutions of different molarity are needed in the hot cell for preparing waste feed and for flushes. This data sheet gives the procedure to prepare $1 \mathrm{~kg}$ of each of these $\mathrm{NaOH}$ solutions from 5.0 mole/L stock solution. Masses of desired solution other than $1 \mathrm{~kg}$ may be linearly scaled using the table below.

\begin{tabular}{|l|r|r|r|}
\hline $\mathrm{NaOH}$ Preparation $/ \mathrm{Kg}$ & \multicolumn{3}{|c|}{ Stock $=5 \mathrm{~mole} / \mathrm{L}$} \\
\hline $\begin{array}{l}\text { Prepared Solution } \\
(\mathrm{mol} / \mathrm{L})\left(27^{\circ} \mathrm{C}\right)\end{array}$ & $\begin{array}{c}\text { Stock } \\
\text { Soln }(\mathrm{g})\end{array}$ & $\begin{array}{c}\mathrm{H} 2 \mathrm{O} \\
(\mathrm{g})\end{array}$ & $\begin{array}{c}\text { Total } \\
(\mathrm{g})\end{array}$ \\
\hline 0.5 & 115.79 & 884.21 & 1000 \\
\hline 0.636 & 146.05 & 853.95 & 1000 \\
\hline 0.676 & 154.93 & 845.07 & 1000 \\
\hline 0.694 & 158.93 & 841.07 & 1000 \\
\hline 0.718 & 164.26 & 835.74 & 1000 \\
\hline 0.749 & 171.14 & 828.86 & 1000 \\
\hline 5.0 & 1000.00 & 0.00 & 1000 \\
\hline
\end{tabular}

\section{Procedure:}

Checksheet\#

1. Quantity of $\mathrm{NaOH}$ solution to be prepared g; desired strength $\mathrm{mol} / \mathrm{L}$

2. Quantity of water required g.

3. For desired strength, from Table above, meter water as:

Tare wt of Beaker\#1 and stirrer: $\mathrm{g}$

Wt. of Beaker\#1, stirrer and water: g

Net wt. of water taken: g

4. Calculate and meter $\mathrm{NaOH}$, from Table above, as:

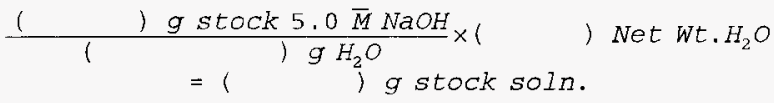

Tare wt of Beaker\#2: g

Wt. of Beaker\#2 and $\mathrm{NaOH}$ : g

Net wt. of $\mathrm{NaOH}$ : $\mathrm{g}$

5. Slowly, over a few minutes, pour preweighed amt. of 5.0 mole/L stock $\mathrm{NaOH}$ solution into the water in the $1 \mathrm{~L}$ beaker on a stir plate, allowing time for blending. Record final solution temp. ${ }^{\circ} \mathrm{C}$.

Final wt. of (beaker + solution) $=$

Wt. of solution prepared $=$ g g. 
HNF-SD-RE-TPI-003, Rev. 0

THIS PAGE INTENTIONALLY LEFT BLANK 
HNF-SD-RE-TPI-003, Rev. 0

Appendix B: Material Safety Data Sheets

B-i 
HNF-SD-RE-TPI-003, Rev. 0

THIS PAGE INTENTIONALLY LEFT BLANK 


\section{List of Material Safety Data Sheets}

Sodium Hydroxide, $\mathrm{NaOH} \ldots \ldots \ldots \ldots \ldots \ldots \ldots \ldots \ldots \ldots \ldots$

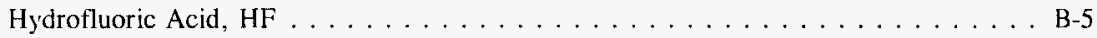

Hydrochloric Acid $\mathrm{HCl} \ldots \ldots \ldots \ldots \ldots \ldots \ldots \ldots \ldots \ldots$

UOP IONSIV Ion Exchanger Type IE-911 (Crystalline Silicotitanate) . . . . . . . . B-19

\section{MSDS Numbers}

MSDS

Sodium Hydroxide, $\mathrm{NaOH} \ldots \ldots \ldots \ldots \ldots$. . . . . . . . . . . . . . . . . . . . . . . . . . . . . . . . . . . . . . . . . . . . . . . . . . . . . . .

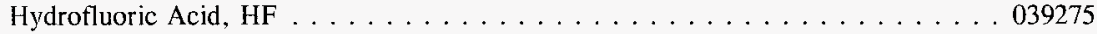

Hydrochloric Acid, $\mathrm{HCl} \ldots \ldots \ldots \ldots \ldots 338$

UOP IONSIV Ion Exchanger Type IE-911 (Crystalline Silicotitanate) . . . . . . . 053329 
HNF-SD-RE-TPI-003, Rev. 0

THIS PAGE INTENTIONALLY LEFT BLANK 
HNF-SD-RE-TPI-003, Rev. 0

$28 / 96 \quad 12: 45: 59$

$1-599-376-2128->$

$5 B 93769964$

Paye 821

Froduct \#: S0899 Name: SODIUM HYDROXIDB PELLETS ACS REAGENT

Material Safety Data Sheet Valid $2 / 95-4 / 95$

Printed: $02 / 22 / 1995 \quad 15: 33: 32$

\begin{tabular}{|c|c|c|}
\hline $\begin{array}{l}\text { Sigma Chemical Co. } \\
\text { P.O. Box } 14508 \\
\text { Se. Louis, MO } 63178 \\
\text { Phone: } 314-771-5765\end{array}$ & $\begin{array}{l}\text { Aldrich Chemical Co., Inc. } \\
\text { lool West St. Faul } \\
\text { Milwaukee, WI } 53233 \\
\text { Phone: } 414-273-3850 \text { Emergency }\end{array}$ & $\begin{array}{l}\text { Eluka Chemical CoIP. } \\
980 \text { South Second St. } \\
\text { Ronkonkoma, NY I1779 } \\
\text { Phone: } 516-467-0980 \\
\text { Phone: } 516-467-3535\end{array}$ \\
\hline
\end{tabular}

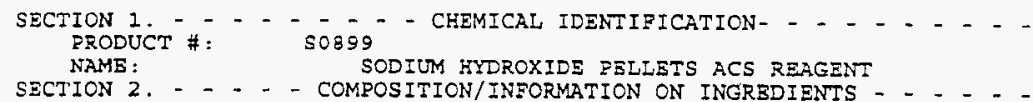

SECTION 2 : $-\overline{-}-\overline{-}$
CAS \#: $1 \overline{3} 10-73-2$

$M F$ : IINAO

SYNONYMS

CAUSTIC SODA * HYDROXYDE DE SODIUM (FRENCH) * LEWIS-RED DEVIL LYE *

LYE * NATRIUMFIDROXID (GERMAN) * NATRIUMHYDROXYDB (DUTCH) * SODA LYE * SODIO(IDROSSIDO DI) (ITALIAN) * SODIUM FYDRATE * SODIUM FYDROXIDB (ACGIH,DSHA) - SODIUM HYDROXIDE, SOLID (UN1823) (DOT) * SODIUM HYDROXIDE, SOLUTION (UN1824) (DOT) * SODIUM (HYDROXYDE DE) (FRENCH) * UN2823 (DOT) * UNI824 (DOT) * WHITE CAUSTIC •

SECTION 3. - - - - - - - - HAZARDS IDRNTIFICATION - - - - - -

- IEL PRECANTIONARY STATEMENTS

CORROSIVE

CAUSES BURNS.

FARMEUL BY INTALATION, IN CONTACT WITH SKIN AND IF SWALLOWED. IN CASE CE CONTACT WITH EYES, RINSE IMMEDIATBLY WITH PLENTY OF HATER AND SBEK MBDICAL ADVICE.

TAKE OEF IMMEDIATBLY ALL CONTAMINATED CLOTHING.

WEAR SUITABLE PROTECTIVE CLOTHING, GLOVES AND EYE/EACE PROTECTION.

SECTION 4. - - - - - - - - - EIRST-AID MBASURES - - - - - - - - -

IN CASE OF CONTACT, IMMEDIATELY FLUSH EYES OR SKIN WITH COPIOUS

AMOUNTS OF HATER FOR AT LEAST 15 MINUTES WHILE REMOVING CONTAMINATED

CLOTHING AND SHOES.

ASSURE ADEQUATE FLUSHING OF TAE EYES BY SBPARATING THE EYELIDS

NITH FINGERS.

IF INHA:BD, REMOVE TO FRESH AIR. IF NOT BREATHING GIVE ARTIFICIAL

RESPIRATION. IF BREATHING IS DIFFICULT, GIVE OXYGEN.

IF SWALLOWED, WASH OUT MOUTH WITH WATER PROVIDED PERSON IS CONSCIOUS.

CALI A SHYSICIAN.

WASH CONTAMINATED CLOTHING BEFORE REUSE.

DISCARD CONTAMINATED SHOES.

SECTION 5. - - - - - - - - FIRE FIGHTING MERSURES - - - - - - - -

EXTINGUISHIING MEDIA

USE EXTLNGUISHING MEDIA APRROPRIATE TO SURROUNDING FIRE CONDITIONS. DO NOT IJSE WATER.

SPECIAI FIREFIGHTING PROCEDURES

WEAR SE:LF-CONTAINED BREATHING APFARATUS AND PROTECTIVE CLOTHING TO PREVENT CONTACT WITH SKIN AND EYES. 
HNF-SD-RE-TPI-003, Rev. 0

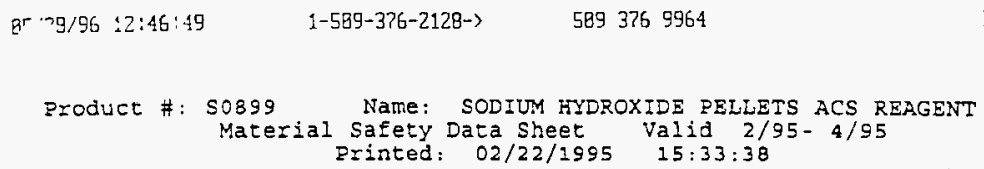

\section{MSDS \#045620}

SMITS TOXIC FUMES UNDER FIRE CONDITIONS.

SECTION 6. - - - - - - ACCIDENTAL RILEASE MEASURES - - - - - -

BVACUATE AREA.

WEAR SEIE-CONTAINED EREATHING APPARATUS, RUEBER BOCTS AND HEAVY

RUBBER GLOVES.

SWEEP UP, PTACE IN A BAG AND HOLD FOR WASTE DISPOSAL.

VENTILATE AREA AND WASA SPILL SITE AFTER MATERIAL PICKUP IS COMPIETE. SECTICI: ; - - - - - - - - HANDIING AND STORAGE- - - - - - - FEFER TO EECIICN 8 .

ADDITIONAL INFORMATION

CONTACT "AITH ALIMINUM, TIN AND ZINC LIBERATES HYDROGEN GAS, CONTACT HITH NITROMETHANE AND OTHER SIMIIAR NITRO COMPOUNDS CAUSES FORMATION OF SHOCK-SENSIIIVE SALTS.

SECTION 8. - - - - - - EXPOSURE CONIROLS/PERSONAL PROTECTION - - - - HEAR APPRORRIATE NIOSH/MSHA-AFPROVED RESPIRATOR, CHEMICAL-RESISTANT GLOVES, SAEBTY GOGGLES, OTHER PROTBCTIVE CLOTHING.

SAFETY SHOWER AND EYR BATH.

USE ONLY IN A CHEMICAL FUME HOOD.

FACESHIELD (8-INCH MINIMUM) .

DO NOT BREATHE DUST.

DO NOT GET IN EYES, ON SKIN, ON CLOTHING.

AVOID PROLONGED OR REFEATED EXPOSURE.

READILY ABSORBED THROUGH SKIN.

HASH THOROUGHLY AETER HANDLING.

TOXIC.

CORROSIVE.

KEEP TIGLTLY CLOSED.

EXTREMELY HYGROSCOPIC

AIR SENSITIVE

STORE IN A COOL DRY PLACE.

SECTION 9. - - - - - - PHYSICAL AND CHEMICAL RRORERTIES - - - - -

AFPEARANCE AND ODOR

WHITE PELISTS

MELTING POINT: $318 \mathrm{C}$

VAPOR ERESSURE: $\quad 18 \mathrm{MM} 20 \mathrm{C} \quad 3 \mathrm{MM} 37 \mathrm{C}$

VAPOR DENSITY: >I

SPECIEIC GRAVITY: 2.130

SECTION 10. - - - - - - -STABILITY AND REACTIVITY - - - - - -

INCOMPATIBILITIES

STRONG OXIDIZING AGENTS

STRONG ACIDS

ORGANIC MATERIALS

CHLORINATED SOLVENTS

ABSORES $\mathrm{CO} 2$ PROM AIR.

PROTECT FROM MOISTURE.

HAZARDOUS COMBUSTION OR DECOMPOSITION PRODUCTS

NATURE OF DECOMFOSITION PRODUCTS NOT XNOWN.

TION 11. - - - - - - - IOXICOLOGICAL INFORMATION - - - - - - 
HNF-SD-RE-TPI-003, Rev. 0

pro $28 / 96: 2: 4: 32$

$1-589-376-2128->$

5893769964

Pecte 923

Product \#: SOB99 Name: SODIUM FYDROXIDE PELLEIS ACS REAGENT

Material Safety Data Sheet Valid 2/95-4/95

Printed: $02 / 22 / 1995 \quad 15: 33: 43$

ACUTE EFEECTS

MSDS \#045620

HARMFUL IF SWALLOWED, INFALED, OR ABSORBED THROUGE SKIN.

MATERIAL IS EXTREMELY DESTRUCTIVE TO TISSUE OF THE MUCOUS MEMBRANES

AND UPPER RESPIRATORY TRACT, EYES AND SKIN.

CAUSES SEVRRE BURNS.

INFALATION MAY BE FATAL AS A RESULT OF SEASM, INELEIMLATION AND EDEMA OF THE IARYNX AND BRONCHI, CHEMICAL PHEUHONITIS ILD EULAONARY EDEMA. SYMPTOMS OF EXPOSURE MAY INCLUDE BURNING SENSATION, COUGHING, WHEEZING, IARYNGITIS, SHORTNESS OF BREATH, HEADACHE, NAUSEA AND VOMITING.

TO THB BEST OE OUR KNOWLEDGE, THE CHEMICAL, PHYSICAL, AND

TOXICOLOGICAL PROPBRTIES HAVE NOT BEEN THOROUGHLY INVESTLGATED.

RTECS NO: WB 4900000 SODIUM HYDROXIDE

IRRITATION DATA

EYE-MKY $1 \% / 24$ SEV

SKN-RBT $500 \mathrm{MG} / 24 \mathrm{H} \mathrm{SEV}$

EYE-RBT 400 UG MLD

TXADA9 $6,701,64$

EYE-RBI 1 \& SEV

EYE-RBT 50 UG/24H SEV

EYE-RBT $1 M G / 24 \mathrm{H} S \mathrm{SV}$

EYE-RBT 1 MG/3OS RINSE SEV

$282 E A K=, 7,72$

OYYAA2 $26,627,83$

AJOPAA $29,1363,46$

28ZPAK $-.7,72$

TXAPA9 $6,701,64$

ICITY DATA

IPR-MUS IDS0:40 MG/KG

TXCYAC $23,281,82$

SELECTED REGISTRY OF TOXIC IFESCIS OR CKEMICAL SUBSTANCES

(RTECS) DATA IS PRBSBNTBD HERE. SEE ACTUAL ENTRY IN RTECS FOR COMPLETE INEORMATION.

SECTION 12 . - - - - - - ECOIOGICAL INEORMATION - - - - - DATA NCT YET AVAILASLE.

SECTION 13. - - - - - - - DISPOSAL CONSIDERATIONS - - - - - - FOR SMAIL QUANIITIES: CAUTIOUSLY ADD TO A LARGE STIRRED EXCESS OE WATER. ADJUST THE PH TO NEUTRAL, SEPARATE ANY INSOLUBLE SOLIDS OR LIQUIDS AND PACKAGE THEM FOR FAZARDOUS-WASTE DISPOSAL, ELUSH THE AOUBOUS SOLUTION DOWN THE DRAIN WITH PLENTY OF WATER. THE HYDROLYSIS AND NEUTRALIZATION REACTIONS MAY GENERATE HEAT AND FUMES HYICH CAN BE CONTROIILED BY THE RATE OF ADDITION.

OBSERVE ALL FEDERAL, STATE AND LOCAL ENVIRONMENTAL REGULATIONS.

SECTION 14. - - - - - - - - - TRANSPORT INEORMATION - - - - - - CONTACT' SIGMA CHEMICAL COMPANY FOR TRANSPORTATION INFORMATION.

SECTION 15. - - - - - - - - - REGULATORY INEORMATION - - - - - - - RBVIEWS, STANDARDS, AND REGUIATIONS

ACGIH TLV-CL 2 MG/M3

85 INA $8,1416,91$

EPA FIERA 1988 FESTICIDE SUBJECT TO REGISTRATION OR RE-REGISTRATION

PEREAC: $54,7740,89$

MSHA STANDARD:AIR-CL $2 \mathrm{MG} / \mathrm{M} 3$

DTLVS* $3,233,71$

OSHA PEL: $8 \mathrm{H}$ TWA $2 \mathrm{MG} / \mathrm{M3}$

FEREAC' $54,2923,89$

OSEA REL FINAL:CL $2 \mathrm{MG} / \mathrm{M3}$

Page 3 
HNF-SD-RE-TPI-003, Rev. 0

Erocuct \#: 50899 Name: SODIUM HYDROXIDE RELLETS ACS REAGENT Material Safety Data Sheet Valid 2/95- $4 / 95$ Printed: $02 / 22 / 1995 \quad 15: 33: 49$

FEREAC $54,2923,89$

OEL-AUSIRALIA: THA $2 \mathrm{MG} / \mathrm{M3} J A N 93$

OEL-BELEIUM:STEL $2 \mathrm{MG} / \mathrm{M} 3$ JAN9 3

OEL-DENMARK: THA 2 MG/M3 JAN93

OEL-RINIAND:TWA 2 MG/M3 JAN93

OEL-FRALICE : THA 2 MG/M3 JAN9 3

OEI-GERVLANY:TWA $2 \mathrm{MG} / \mathrm{M} 3$ JAN93

OEL-JAFAN:STEL $2 \mathrm{MG} / \mathrm{M} 3$ JAN93

OEL-THE NITHERLANDS: THA $2 \mathrm{MG} / \mathrm{M} 3$ JAN93

OEL-TEE PHIIIPEINES:TWA 2 MG/M3 JAN93

OEI-SWELIBN: THA 2 MG/M3 JAN93

OEL-SWITZZRLAND:TNA 2 MG/M3;STEL $4 \mathrm{MG} / \mathrm{M3}$ JAN93

OEL-THAILAND: TWA 2 MG/M3 JAN93

OBL-TURKEY:THA 2 MG/M3 JAN93

OEL-UNIIED XINGDOM:TWA 2 MG/M3;STEL 2 MG/M3 JAN93

OEL IN EULGARIA, COLOMBIA, JORDAN, KORBA CHECX ACGIH TLV

OEL IN NEE ZBAIALD, SINGAPORE, VIETNAM CHECK ACGIE TLV

NIOSH REL TO SODIUT HYDROXIDE-AIR:CL 2 MG/M3/15M

NIOSH* DHHS \#92-100,92

NOHS 1974: NZD 69070; NIS 359; TNE 112525; NOS 192; TNE 1122583

NOES 1983: HZD X3782; NIS 164; TNE 20410; NOS 117; TNE $332750 ;$ TFE

123903

NOES 1983: KZD 69070; NIS 394; TNF 107562; NOS 231; TNE 2233346; TFE

740163

EPA GENETOX PROGRAM 1988, NEGATIVE: CELI TRANSEORM.-SA7/SHE

EFA TSCA. CHBMICAL INVENTORY, JUNB 1993

EPA TSCA. SECTION $8(E)$ STATUS REPORT BBHQ-0485-0552

EPA TSCA. TEST SUBMISSION (ISCATS) DATA BASE, JULY 1994

NIOSH ANALYTICAL METHODS: 5BE ALKALINE DUSTS, 7401

SECTION 16. - - - - - - - - - OTHER INPORMATION - - - - - - IHE ABOVE INFORMATION IS BELIEVED TO BE CORRECT BUT DOES NOT PURFORT TO BE ALL INCEUISIVI AND SHALL BE USED ONLY AS A GUIDB. SIGMA, ALDRICH, FLUKA SHALL NOT BE GELD LIABLE FOR ANY DAMAGE RESULTING FROM FIANDLING OR FROM CONTACT WITH THE ABOVE PRODUCT. SEE REVERSE SIDE OF INVOICE OR PACKING SLIF FOR ADDITIONAL TERMS AND CONDITIONS OF SALE. COPYRIGHT 1994 SIGMA CHEMICAL CO., ALDRICH CHEMICAL CO., INC., FLUKA CHEMIE AG

LICENSE GRANTED TO MAKE UNLIMITED PARER COPIES FOR INTERNAL USE ONLY 
HNF-SD-RE-TPI-003, Rev, 0

$79 / 46 \quad 99: 86: 47$

$1-599-376-2128->$

5993759964

Page 892

PAGE 01 OF 08

SUBSTANCE IDENTIFICATION

CAS-NUMEER 7564-39-3

SUBSTANCE: MYYDROFLUORIC ACID REAGENT ACS

MSDS \#039275

TRADE NAMES/SYNONYMS:

FLUORIC ACID; HYDROFLUORIC ACID SOLUTION; UN 1790; RCRA U134; IIF; OIS 1172

CHEMICAL FAYILY:

INORGANIC ACID

MOLECULAR FORYULA: II-F

CERCLA RATINGS (SCALE 0-3): IIEALTH=3 FIRE=0 REACTIVITY=1 PERSISTENCE $=0$ NTPA RATINGS (SCALE 0-4): IIEALTII $=4$ FIRE=0 REACTIVITY $=1$ COMPONENTS AND CONTAMINANTS

COMPONENT: IIYDROGEN FLUORIDE PERCENT: 49.0

COMPONENT: WATER

PERCENT: 51.0

EXPOSURE LIHITS:

HYDROGEN FLUORIDE, AS E:

3 PPH OSIIA TWA; $S$ PPH OSILA STEL

PPH (2.5 HG/M3) ACGIII CEILING

$\therefore$ PPM $(2.5 \mathrm{MG} / \mathrm{M3})$ NIOSII RECOMKENDED 10 IIOUR TWA:

$6 \mathrm{PPM}$ ( $5 \mathrm{MG} / \mathrm{M3}$ ) NIOSI RECOHHENDED I5 MINUTE CEILING

100 POUNDS SARA SECTION 302 TIIRESIIOLD PLANNING QUANTITY

100 POUNDS SARA SECTION 304 REPORTABLE QUANTITY

100 POUNDS CERCLA SECTION 103 REPORTABLE QUANTITY

SUBJECT TO SARA SECTION 313 ANNUAL TOXIC CIIEMICAL RELEASE REPORTING

PIIYSICAL DATA

DESCRIPTION: COLORLESS TO SLIGITLY YELLOW LIQUID HITH A PUNGENT ODOR. BOILING POINT: 225 F $(107 \mathrm{C})$ MELTING POINT: $-35 \mathrm{~F}(-37 \mathrm{C})$ (APPROX.) SPECIFIC GRAVITY: $1.15-1.18$ VAPOR PRESSURE: 25 MMHG $20 \mathrm{C}$ PII: <2 SOLUBILITY IN WATER: SOLUDLE 
HNF-SD-RE-TPI-003, Rev. 0

E $9 / 9689: 07: 22$

$1-589-376-2128->$

5893769964

Page 683

PAGE 02 OF 08

TIRE AND EXPLOSION IIAZARD:

VEGLIGIBLE FIRE UAZARD WHEN EXPOSED TO IIEAT OR FLAME.

NSDS $\#, 039275$

FIREFIGHTING MEDIA:

DRY CIIEMICAL, CARDON DIOXIDE, HALON, WATER SPRAY OR ALCOIOL FOAM

(1987 EMERGENCY RESPONSE GUIDEDOOK, DOT P 5800.4).

FOR LARGER FIRES, USE WATER SPRAY, TOG OR STANDARD FOAM

(1987 EMERGEIVY RESPONSE GUIDEDOOK, DOT P 5800.4 ).

FIRETIGITING :

MOVE CONTAINERS FROM FIRE AREA IF POSSIBLE. COOL CONTAINERS EXPOSED TO FLAMES

WITH WATER FROM SIDE UNTIL WELL AFTER FIRE IS OUT. STAY AWAY FROH STORAGE TANK

ENDS ( 1987 EMERGENCY RESPONSE GUIDEDOOK, DOT P 5800.4, GUIDE PAGE 59).

DO NOT USE WATER ON MATERIAL. EXTINGUISII USING AGENTS SUITABLE FOR TYPE OF FIRE. USE ELOODING AYOUNTS OF WATER AS FOG. COOL CONTAINERS WITH FLOODING AMOUNTS OF WATER, APPLY FROM AS FAR A DISTANCE AS POSSIBLE. AVOID BREATHING CORROSIVE VAPORS, KEEP UPWIND.

TRANSPORTATION DATA

RTMENT OF TRANSPORTATION HAZARD CLASSIEICATION 49CER172.101: CORROSIVE MATERIAL

DEPARTMENT OF TRANSPORTATION LABELING REQUIRIMENTS 49CFR172.101 AND SUDPART E: CORROSIVE

DEPARTMENT DF TRANSPORTATION PACKAGING REQUIREMENTS: 49CRR173.264

EXCEPTIONS: 49 CFR173.244

TOXICITY

HYDROGEN FLUORIDE:

50 MG EYE-IIUMAN SEVERE IRRITATION; 100 MG/M3/1 MINUTE INHALATION-MAN TCLO;

50 PFM/30 MINUTES INHALATION-HUHAN LCLO; 1275 PPM/I IIOUR INIIALATION-RAT LC5O;

342 PPM/1 IIOUR INHALATION-MOUSE LC50; 1774 PFH/I HOUR INHALATION-MONKEY LC5O;

$260 \mathrm{MG} / 43 / 7$ HOURS INHALATION-RADBIT LCLO; 4327 PPH/15 MINUTES

INIALATION-GUINEA PIG LC50; $500 \mathrm{HG} / K G$ SKIN-YOUSE LDLO; $25 \mathrm{HG} / \mathrm{KG}$

INTRAPERTTCNEAL-RAT LDLO; MUTAGENIC DATA (RTECS); REPRODUCTIVE EFFECTS DATA

(RTECS).

CARCINOGEN STATUS: NONE.

IIYDROGEN FLUORIDE IS TOXIC AND A SEVERE EYE, SKIN AND MUCOUS MEMBRANE IRRITANT. CHRONIC EXPOSURE MAY PRODUCE FLUOROSIS OF THE SKELETAL SYSTEM.

HEALTH EFFECTS AND EIRST AID

SNIIALATION:

IYYDROGEN FLUORIDE:

CORROSIVE/'TOXIC. 30 PPM IMMEDIATELY DANGEROUS TO LIFE OR IIEALTII.

CUTE EXPOSURE- TWO IIUMAN SUBJECTS EXPOSED TO 120 PPM EXPERIENCED MARKED RESPIRATORY IRRITATION. TIIS WAS THE HIGHEST CONCENTRATION TIIAT COULD BE TOLERATED FOR MORE THAN ONE MINUTE. 30 PPM CAUSED MILD NASAL IRRITATION 
HNF-SD-RE-TPI-003, Rev. 0

$39 / 36$ 89:88:17

$1-589-376-2128->$

5893759964

Page 384

\section{MSDS \# 03927.5}

AND COULD BE TOLERATED FOR SEVERAL MINUTES. HIGIILR CONCENTRATIONS MAY CAUSE TRANSIENT CHOKING, COUGHING, CIIILLS, CIIEST PAIN AND CONSTRICTION, AND DYSPNEA. AN ASYMPTOMATIC PERTOD OF 12-48 HOURS MAY BE FOLLOWED BY FEVER, COUGH, DYSPNEA, CYANOSIS, RALES, AND PULMONARY EDEMA OR DRONCHIAL PNEUYONTA. IN HUMANS, KIDNEY DAMAGE HAS ONLY BEEN REPORTED IN SEVERE, ACUTE OVEREXPOSURES. IN TOUR SEPARATE EVENTS, 9 WORKERS WERE SPLASIIED WITII IIYDROFLUORIC ACID; 6 DIED. DEATI OCCURRED 2-10 HOURS AFTER EXPOSURE AND WAS CAUSED BY PULMONARY EDEMA, IILMORRHAGIC PULHONARY EDEMA AND ULCERATIVE TRACHEOBRONCHITIS, OR CARDIAC ARREST, IN ONE INSTANCE, THE DREATHING ZONE CONCENTRATION WAS ESTIMATED TO BE ADOVE 10,000 PPH.

CIIRONIC EXPOSURE- 5 IIUMAN SUBJECTS EXPOSED 6 IIOLRS/DAY, 5 DAYS/WEEK, FOR 10-50 DAYS AT AVERAGE CONCENTRATIONS OF UP TO 4.7 PPM EXPERIENCED SLIGIIT NASAL IRRITATION. REPEATED EXPOSURE TO LOW CONCENTRATIONS MAY CAUSE NASAL CONGESTION, NOSEDLEEDS, SINUS PROBLEMS, AND DRONCIIITIS. ABSORPTION OE EXCESSIVE AMOUNTS OF FLUORINE MAY RESULT IN FLUOROSIS, A SYNDROME CIIARACTERIZED BY OSTEOSCLEROTIC BONE CILANGES. CASES OT VARYING DEGREES OF OSTEOSCLEROSIS IIAVE DEEN REPORTED IN WORKERS EXPOSED TO HYDROGEN FLUORIDE FOR A NUMBER OF YEARS, USUALLY 3 OR MORE. THE FIRST EVIDENCE OF CIIANGE IS MOST APPARENT IN THE PELVIS AND LUMBAR SPINE AND MAY DE ACCOMPANIED BY HILD TO MODERATE BACK PAIN AYD STITENESS. PRESUMABLY, OTHER SYMPTONS OF FLUOROS IS, WEIGHT LOSS, GENERAL ILL HEALTI, ANEMIA, BRITTLENESS OF TIE BONES, AND DISCOLORATION OF DEVELOPING TEETH, ARE ALSO POSSIBLE. ANIHAL STUDIES INDICATE THAT REPEATED EXPOSURE MAY CAUSE PULMONARY, HEPATIC AND RENAL TISSUE DAMAGE. EXPOSURE OF PREGNANT RATS FOR 22 DAYS RESULTED IN IN EFFECTS ON FERTILITY AND ON THE FETUS.

$\therefore$.ST AID- REMOVE FROM EXPOSURE AREA TO FRESII AIR IMMEDIATELY. IF BREATHING HAS STOPPED, GIVE ARTIFICIAL RESPIRATION. MAINTAIN AIRWAY AND BLOOD PRESSURE AND ADMINISTER OXYGEN IF AVAILADLE. KEEP AFFECTED PERSON WARM AND AT REST. TREAT SYMPTOMATICALLY AND SUPPORTIVELY. ADMINISTRATION OF OXYGEN SHOULD BE PERFORMED BY QUALITILD PERSONNEL. GET MEDICAL ATTENTION IMMEDIATELY.

SKIN CONTACT:

HYDROGEN FLUORIDE:

CORROSIVE.

ACUTE EXPOSURE- IYDROGEN FLUORIDE DURNS ARE CIIARACTERIZED BY A BLANCHED APPEARAYCE OF TIIE SKIN WITII PERSISTENT EXCRUCIATING PAIN, EDEMA AND NECROSIS. WITII CONCENTRATIONS LESS TIIAN 20X, PAIN AND ERYTHEMA MAY OCCUR AFTER A LATENT PERIOD OF 24 HOURS. WITH $20-50 \times$ SOLUTIONS, DURNS MAY BE APPARENT WITHIN 1-8 HOURS. WITII CONCENTRATIONS GREATER THAN 50X, IMMEDIATE PAIN AND RAPIDLY APPARENT TISSUE DAKAGE OCCUR ON CONTACT. SMALL AMOUNTS OF HYDROGEN FLUORIDE WIIICII ARE NOT WASHED OFF MAY CAUSE DELAYED DEVELOPYENT OF NON-HEALING ULCERS. FINGERNAILS AND NAIL BEDS MAY BE COMPLETELY DESTROYED. PENETRATION OF TIIE FLUORIDE ION TO DEEP TISSUES HAY RESULT IN SLOW HEALING NECROSIS OF SOFT TISSUES AND DECALCIEICATION OF DONE. VAPORS AT A CONCENTRATION OF OF 120 PPM CAUSED SMARTING OF EXPOSED SKIN IN PEOPLE IN ONE MINUTE. SYSTEMIC FLUORIDE POISONING TIIROUGH SKIN ABSORPTION MAY OCCUR. STUPOR, UNRESPONSIVENESS TO STIMULI OTHER THAN PAIN, SEVERE NAUSEA, VOHITING, AND REDUCED PULSE RATE WERE REPORTED IN ONE CASE.

CIIRONIC EXPOSURE- REPEATED OR PROLONGED EXPOSURE MAY CAUSE IRRITATION OR DURNS. SLIGIIT IRRITATION OCCURRED IN PEOPLE EXPOSED TO VAPOR

CONCENTRATIONS AVERAGING 2.6 AND 4.7 PPM FOR PERIODS OF UP TO 50 DAYS. SLIGIIT DESQUAMATION OF THE SUPERTICIAL EPITIELIUM OF TIII FACE WAS ODSERVED IN ONE SUBJECT AFTER TEN DAYS OF EXPOSURE TO HYDROGEN FLUORIDE AT 3.4 PPM. 
HNF-SD-RE-TPI-003, Rev. 0

$79 / 96$ 89:89:41 1-589-376-2128-> $5893769964 \quad$ Page 865

\section{MSDS \#03927.5 PAGE 04 OF 08}

FIRST AID- REMOVE CONTAMINATED CLOTIING AND SHOES IMMEDIATELY. WASH AFFECTED AREA WITH SOAP OR MILD DETERGENT AND LARGE AKOUNTS OF WATER UNTIL NO EVIDENCE OF CHEMICAL REMAINS (AT LEAST 15-20 MINUTES). IN CASE OF CHEMICAL BURNS, COVER AREA WITII STERILE, DRY DRESSING. BANDAGE SECURELY, DUT NOT TOO TIGHTLY. GET MEDICAL ATTENTION IMMEDIATELY.

TYE CONTACT:

IIYDROGEN FLUCRIDE:

CORROSIVE.

ACUTE IXFOSURE- EXPOSURE TO HYDROGEN FLUORTDE AVERAGING 4.7 PPM FOR 6 HOURS, OT: 30 PPM FOR SEVERAL HINUTES CAUSED MILD IRRITATION, WHILE 120 PPM RESULTED IN MARKED CONJUNCTIVAL IRRITATION WITIIIN 1 MINUTE IN HUMANS. IIRECT CONTACT WITH THE LIQUID OR SOLUTIONS MAY CAUSE CORNEAL BURNS. IF NOT PROMPTLY REMOVED, PERMANENT VISUAL DEFECTS OR BLINDNESS MAY RESULT. ONE WORKER EXPOSED TO A FINE SPRAY OF CONCENTRATED HYDROGEN FLUORIDE, HAD LOSS OF EPITHELIUM FROM THE CORNEA AND CONJUNCTIVA, AND MARKED ELEMA OF THE EYELIDS, CONJUNCTIVA, AND CORNEAS; PROMPT TREATMENT WAS ADMINISTERED. NORMAL VISION WAS REGAINED WITIIN I9 DAYS.

CURONIC EXFOSURE- HUMANS EXPERIMENTALLY EXPOSED TO CONCENTRATIONS WHICH AVERAGED 2.6-4.7 PFM TOR UP TO 50 DAYS DEVELOPED MILD EYE IRRITATION. IN ANIHAI,S, REPEATED OR PROLONGED EXPOSURE TO LOW VAPOR CONCENTRATIONS CAUSED SIIGHT LACRIMATION.

r.. AID- WASH EYES IMMEDIATELY WITH LARGE AMOUNTS OE WATER, OCCASIONALLY ITING UPPER AND LOWER LIDS, UNTIL NO EVIDENCE OF CIIEMICAL REMAINS (AT LEAST 15-20 MINUTES). CONTINUE IRRIGATING WITH NORMAL SALINE UNTIL TIIE PII IIAS RETURNED TO NORMAL (30-60 MINUTES), COVER WITH STERILE BANDAGES. GET MEDICAL ATIENTION IMMEDIATELY.

INGESTION :

HYDROGEN FLUORIDE:

CORROSIVE.

ACUTE EXPOSURE- INGESTION MAY CAUSE BURNS OF THE MOUTH, ESOPIIAGUS, STOMACH AND SMAL? INTESTINE WITH GASTRITIS, GASTRIC IIEMORRHAGES, VOMITING, NAUSEA, ABDOHINAI, PAIN, AND DIARRHEA. LARGE DOSES HAY CAUSE EXTENSIVE NECROSIS WITH PERFORATION OF THE STOMACII, SIOCK AND DEATII. SYSTEMIC POISONING MAY CAUSE IIYPOGLYCEMIA, IIYPERXALEMIA, HYPOMAGNESEMIA, AND SEVERE IYYPOCALCEYIA RESULTING IN TETANY, ESPECIALLY OF THE EXTREMITIES, AND PARESTHESIAS. HYPOTENSION, CIRCULATORY SIOCK AND CARDIAC ARRIYTHMIAS INCLUDING SINUS TACHYCARDIA OR VENTRICULAR FIDRILLATION, SOMETIMES PRECEDED BY TACIIYCARDIA, MAY OCCUR. CENTRAL NERVOUS SYSTEM SYMPTOMS MAY INCLUDE HEADACHE, EXCESSIVE SALIVATION, NYSTAGKUS AND DILATED PUPILS, LETHARGY, STUPOR, COMA, AND RARELY, TRANSIENT CONVULSIONS. DEATII IS USUALLY DUE TO RESPIRATORY PARALYSIS OR CARDIAC FAILURE. IN NON-FATAL CASES, JAUNDICE AND KIDNEY DAMAGE WITH ALBUMINURIA, IIEMATURIA, OLIGURIA OR ANURIA MAY OCCUR, DUT ARE GENERALLY REVERSIBLE. ASPIRATION YAY LEAD TO CHEMICAL PNEUMONITIS. CHRONIC EXPOSURE- CIIRONIC INGESTION OF SMALL AYOUNTS MAY CAUSE FLUOROSIS WITH OSTEOSCLEROTIC THICKENING WITH CALCIEICATION IN LIGAMENTOUS ATTACHKENTS OF SKELETON, WEIGKT LOSS, BRITTLENESS OF BONES, REDUCED DONE MARIOW SPACE WITH ANEMIA, WEAKNISS, GENERAL ILL HEALTH, STIFFNESS OF JOINT'S, AND DISCOLORATION OF DEVELOPING TEETII. RARELY, CENTRAL NERVOUS SYSTEM INVOLVEMENT OCCURS.

FIRST AID- DO NOT USE GASTRIC LAVAGE OR EHESIS. DILUTE THE ACID IMMEDIATELY DRINKING LARGE QUANTITIES OF HATER OR YILK. IF VOMITINO PERSISTS, AWHINISTER FLUIDS REPEATEDLY. INGESTED ACID MUST BE DILUTED APPROXIMATELY 
PAGE 05 OF 08

100 FOLD TO RENDER IT IIARMLESS TO TISSUES. MAINTAIN AIRWAY AND TREAT SHOCK (DREISBACI, IIANDBOOK OF POISONING, 12TH ED.). GET HEDICAL ATIENTION

IKKEDIATELY. IF VOMITING OCCURS, KEEP HEAD BELOW HIPS TO IJELP PREVENT ASPIRATION.

ANTIDOTE:

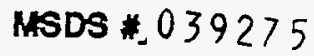

NO SPECIFIC ANTIDOTE. TREAT SYMPTOMATICALLY AND SUPPORTIVELY.

REACTIVITY :

REACTS EXOTHERHICALLY WITH WATER OR STEAM WITII THE RELEASI OF TOXIC AND CORROSIVE FUMES.

INCOHPATIBILITIES:

IIYDROGEN FLUORIDE:

ACETIC ANIIYDRIDE: TEMPERATURE AND PRESSLRE INCREASE IN A CLOSED CCNTAINER. 2-AHINOETIIANOL: TEMPERATURE AND PRESSURE INCREASE IN A CLOSED CONTAINER. AMMONIUM HYDROXIDE: TEKPERATURE AND PRESSURE INCREASE IN A CLOSED CONTAINER. ARSENIC TRIOXIDE: INCANDESCENT REACTION.

BISHUTHIC ACID: VIOLENT REACTION EVOLVING OZONISED OXYGEN.

CALCIUM OXIDE: VERY VIOLENT REACTION HITII INCANDESCENCE.

CILLOROSULFURIC ACID: TEMPERATURE AND PRESSURE INCREASE IN A CLOSED CONTAINER.

OATINGS : ATTACKED. JNCRETE: ATTACKED.

CYANOGEN FLUORIDE: EXPLOSIVE POLYMERIZATION REACTION. DIPIIOSPIIOTIOUS PENTOXIDE: VIOLENT REACTION. EIIIYLNEDIAYINE: TEMPERATURE AND PRESSURE INCREASE IN A CLOSED CONTAINER. ETHYLENEIHINE: TEHEERATURE AND PRESSURE INCREASE IN A CLOSED CONTAINER. FLUORINE: ENERGETIC REACTION WITH IGNITION.

GLASS: ATTACKED.

LEATIIER: ATTACKED.

METALS: MAY GENERATE FLAHMABLE IIYDROGEN GAS UPON CONTACT.

MERCURY OXIDE: EXOTHERMIC REACTION UNLESS ADEQUATE COOLING KEEPS REACTION TEMPERATURE BELOW O $\mathrm{C}$.

METHANESUI,FONIC ACID: ELECTROLYSIS OF A MIXTURE PRODUCED OXYGEN DIFLUORIDE WIIICII EXPLODED.

NITRIC ACID: IGNITION.

NITRIC ACID + GLYCEROL: TEMPERATURE AND PRESSURE INCREASE IN A CLOSED CONTAINER.

NITRIC ACID + LACTIC ACID: UNSTABLE MIXTURE.

NITRIC ACID, PROPYZENE GLYCOL, AND SILVER NITRATE: UNSTABLE MIXTURE.

OLEUH: TENPERATURE AND PRESSURE INCREASE IN A CLOSED CONTAINER.

ORGANIC MATERIALS: ATTACKED.

N-PHENYLAZOPIPERIDINE: VIOLENT REACTION.

PHOSPHORUS (V) OXIDT: VIGOROUS REACTION BELOW $20 \mathrm{C}$.

PLASTICS: ATTACKED.

POTASSIUM PERMANGANATE: VIOLENT, EXOTHERMIC REACTION WITH CONCENTRATED ACID.

POTASSIUM TETRAFLUORISILICATE: VIOLENT EVOLUTION OF SILICON TETRAFLUORIDE. PROPIOLACTONE (IETA): TEMPERATURE AND PRESSURE INCREASE IN A CLOSED CONTAINER.

PROPLYLENE: OXIDE: TEHPERATURE AND PRESSURE INCREASE IN A CLOSED CONTAINER. RUBBER (NATURAL): ATTACKED.

SILICA COITAINING MATERIALS: CORROSIVE.

DDIUM: REACTS WITH EXPLOSIVE VIOLENCE WITII AQUEOUS ACID.

JDIUM HYIROXIDE: TEMPERATURE AND PRESSURE INCREASE IN A CLOSED CONTAINER. 
HNF-SD-RE-TPI-003, Rev. 0

- $39 / 36 \quad 89: 11: 59$

$\therefore$

SULEURIC ACID: TEMPERATURE AND PRESSURE INCREASE IN A CLOSED

PAGE 06 OF 08

TETRAFLUOROSILICIC ACID: VIOLENT REACTION.

CONTAINER.

VINYL ACETATE: TEMPERATURE AND PRESSURE INCREASE IN A CLOSED CONTAINER.

DECOMPOS ITIO:Y :

MSDS * 039275

TIJERHAL DECOHPOSITION MAY RELEASE CORROSIVE IIYDROGEN FLUORIDE.

POLYMERIZATION :

IAZARDOUS POLYMERTZATION IIAS NOT BEEN REPORTED TO OCCUR UNDER NORHAL TEYPERATURES AND PRESSURES.

STORAGE AND DISPOSAL

OBSERVE ALL EEDERAL, STATE AND LOCAL REGULATIONS WHEN STORING OR DISPOSING

OF TIIS SUBSTANCE. EOR ASSISTANCE, CONTACT THE DISTRICT DIRECTOR OF THE

ENVIRONMENTAL PROTECTION AGENCY.

\section{**STORAGE**}

PROTECT AGAINST PHYSICAL DAMAGE. STORE IN HELL-VENTILATED AREA, SEPARATED FROM OTHER STORAGE (NFPA 49, HAZARDOUS CHEYICALS DATA, 1975 ).

STORE AWAY FROM INCOMPATIBLE SUBSTANCES.

**DISPOSAL**

DISPOSAL MUST BE IN ACCORDANCE WITII STANDARDS APPLICABLE TO GENERATORS OR HAZARDOUS WASTE, 40 CFR 262 . EPA HAZARDOUS WASTE NUMBER DOO 2.

100 POUND CERCLA SECTION 103 REPORTADLE QUANTITY.

CONDITIONS TO AVOID

HAY BURN BUT DOES NOT IGNITE READILY. MAY IGNITE COMBUSTIBLES (WOOD, PAPER, OIL, ETC.).

\section{SPILL AND LEAK PROCEDURES}

SOIL SPILL:

DIG IOLDING AREA SUCII AS LAGOON, POND OR PIT FOR CONTAINMENT,

DIKE FLOW OF SPILLED MATERIAL USING SOIL OR SANDBAGS OR FOAMED BARRIERS SUCH AS POLYURETHANE OR CONCRETE.

USE CEMENT POWDER OR FLY ASH TO ABSORB LIQUID MASS.

NEUTRALIZE SPILL WITH SLAKED LIME, SODIUM BICARBONATE OR CRUSHED LIMESTONE.

AIR SPILI:

APPLY WATER SPRAY TO KNOCK DOWN AND REDUCE VAPORS. KNOCK-DOWN HATER IS

CC OSIVE AND TOXIC AND SIIOULD BE DIKED FOR CONTAINHENT. 
VENTILATION :

PROCESS ENCLOSURE RECOMMENDED TO MEET PUDLISHED EXPOSURE LIMITS.

RESPIRATOR:

- FOLLOWING RESPIRATORS AND MAXIMUY USE CONCENTRATIONS ARE RECOHMENDATIONS IY THE U.S. DEFARTMENT OF HEALTH AND HUMAN SERVICES, NIOSH POCKET GUIDE TO CHEMICAL IIAZARDS; NIOSIJ CRITERIA DOCUMENTS OR BY THE U.S. DEPARTMENT OF LABOR, 29. CER 1910 SUBPART $Z$.

THE SPECIFIC RESPIRATOR SELECTED MUST BE BASED ON CONTAMINATION LEVELS FOUND IN THE WORK PLACE, MUST NOT EXCEED THE WORKING LIHITS OF THE RESPIRATOR AND BE JOINTIY APPROVED BY THE NATIONAL INSTITUTE TOR OCCUPATIONAL SAFETY AND

HEALTII AND THE MINE SAFETY AND HEALTII ADMINISTRATION (NIOSH-MSHA).

HYDROGEN FIUORIDE:

30 PPM- ANY SUPPLIED-AIR RESPIRATOR

ANY: SELF-CONTAINED DREATIIING APPARATUS.

ANY: POWERED AIR-PURIFYING RESPIRATOR HITH CARTRIDGE(S) PROVIDING PROTECTION AGAINST HYDROGEN FLUORIDE.

ANY CHEHICAL CARTRIDGE RESPIRATOR WITH CARTRIDGE(S) PROVIDING I'ROTECTION AGAINST HYDROGEN FLUORIDE.

ANY AIR-PURIFYING FULL FACEPIECE RESPIRATOR (GAS MASK) WITH A CHIN-STYLE OR ERONT- OR BACK-MOUNTED CANISTER PROVIDING PROTECTION AGAINST HYDROGEN FLUORIDE.

ESCAPE- ANY AIR-PURIFYING TULL FACEPIECE RESPIRATOR (GAS MASK) WITH A CHIN - STYLE OR FRONT- OR BACK-MOUNTED CANISTER PROVIDING PROTECTION AGAINST HYDROGEN FLUORTDE.

ANY APPROPRIATE ESCAPE-TYPE SELF-CONTAINED BREATHING APPARATUS.

FOR FIREFIGHTING AND OTHER IMMEDIATELY DANGEROUS TO LIFE OR HEALTI CONDITIONS:

SELF-CONTAINED BREATHING APPARATUS WITH FULL FACEPIECE OPERATED IN

PRESSURE-DEMAND OR OTIER POSITIVE PRESSURE MODE.

UPPLIED-AIR RESPIRATOR WITH FULL FACEPIECE AND OPERATED IN PRESSURE-DEMAND OR OTIIER POSITIVE PRESSURE MODE IN COMBINATION WITII AN AUXILIARY 
HNF-SD-RE-TPI-003, Rev. 0 SELF-CONTAINED BREATIIING APPARATUS OPERATED IN PRESSURE-DEMAND OR OTHER POSITIVE PRESSURE MODE.

\section{MSDS \#. 03.227.5}

CLOTHING:

EMPLOYEE HUS" WEAR APPROPRIATE PROTECTIVE (IMPERVIOUS) CLOTHING AND EQUIPMENT TO PREVENT ARY POSSIBILITY OF SKIN CONTACT WITH THIS SUBSTANCE.

GLOVES :

EMPLOYEE MUST WEAR APPROPRIATE PROTECTIVE GLOVES TO PREVENT CONTACT WITI TIIS SUBSTANCE.

EYE PROTECTION:

IMPLOYEE MUST WEAR SPLASII-PROOF OR DUST-RESISTANT SAFETY GOGGLES AND A

FACESHIELD TO PREVENT CONTACT WITH THIS SUBSTANCE.

EMERGENCY WA:II FACILITIES:

HHERE THERE IS ANY POSSIBILITY THAT AN EMPLOYEE'S EYES AND/OR SKIN MAY BE

EXPOSED TO THIS SUBSTANCE, THE EMPLOYER SHOLLD PROVIDE AN EYE WASII FOUNTAIN AND QUICK DRENCH SIIOWER WITHIN THE IMMEDIATE WORK AREA FOR EMERGENCY USE.

AUTHORIZED DY - SEECTRUM CIIIMICAL MIG. CORP.

CREATION DATE: 03/08/89 FEVISION DATE: $11 / 02 / 89$


HNF-SD-RE-TPI-003, Rev. 0

- ECTRUH CIIEKICAL MFG. CORP. 14422 S. San Pedro Street Gardena, CA 90248-9985 Phone: (213) 516-8000
EMERGENCY CONTACT: CIIEHTREC (800) 424-9300

SPECTRUM TECINICAL SERVICE (213) 516-8000

MSDS 039275

The statements contained herein are offered for informational purposes only and are intended to be followed only by persons having related technical skilis and at their own discretion and risk. Since conditions and manner of use are outside our control, we make no warranties, express or implied, and no liability in connection with any use of this information. 
HNF-SD-RE-TPI-003, Rev. 0

$28 / 96 \quad 38: 5 ! 5: 58$

$1-589-376-2128->$

5893769964

. Paye 982

\begin{abstract}
RRODUCT \#: 26759 NAME: HYIROCHLORIC ACID REAGENT
MATERIAL SAEETY DATA SHEEZ, Valid $2 / 96-4 / 96$

Printed Thursday, Februazy 01, 1996 10:50A
\end{abstract}

Sigma chemical co.

P.O. Box 14508

St. Louis, MO 63178

Ehone: 314-771-5765
Aldzich chemica: co., Inc.

1002 West St. ?aut

Milwaukee, $W \vdots 53233$

Fhone: $4 \pm 4-273-3650$
Fluka chemical corp. g80 South Second st. Ronkonkome, NY 11779

Ehone: $516-467-0980$

Enezgercy Phone: $515-467-3535$

\title{
MSDS 036338
}

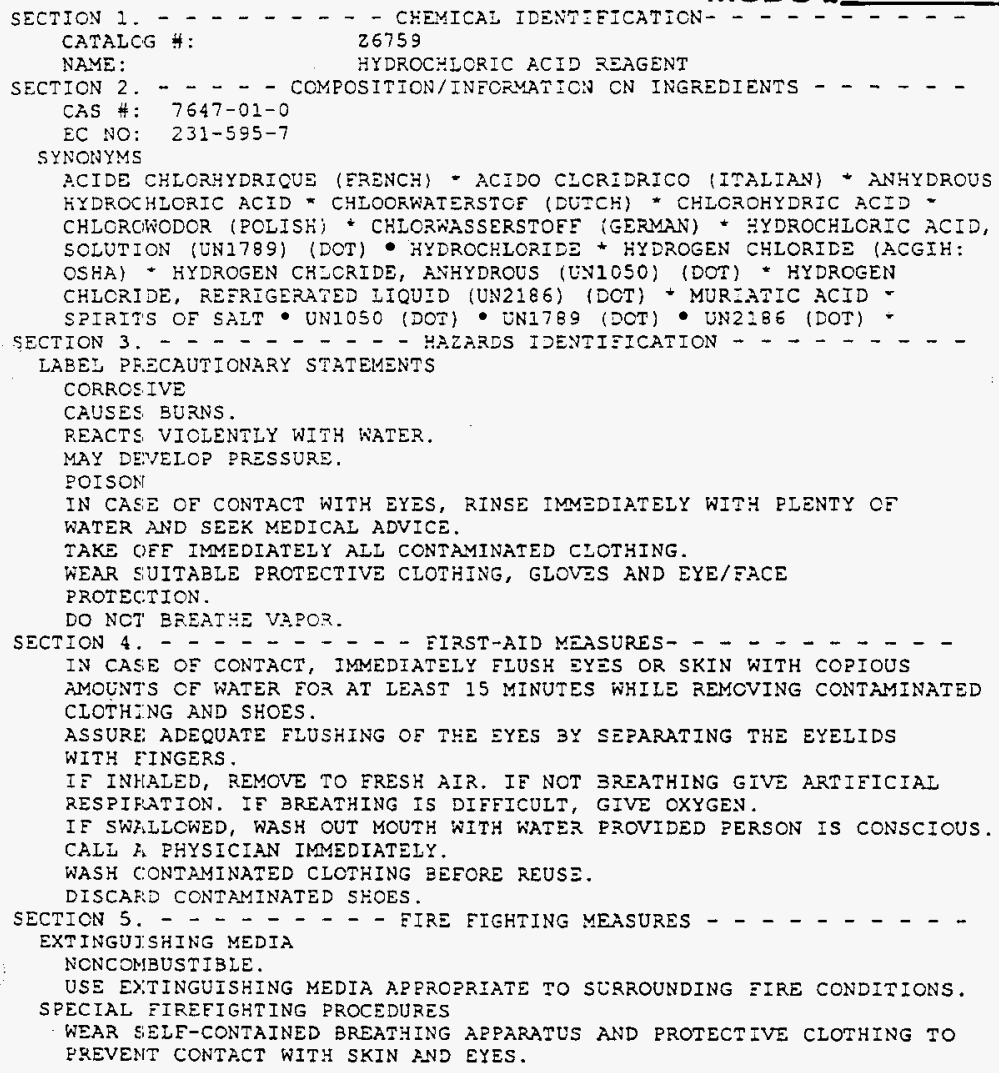


HNF-SD-RE-TPI-003, Rev. 0

:9/96 $38: 56_{1}: 47$

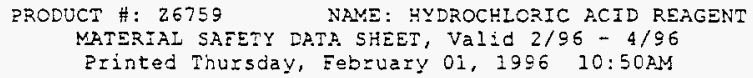

USE WATER SPRAY TO COOI EIRE-EXPOSEE CONTAINERS. UNUSUAL FIRE AND EXFLOSIONS YAZARDS

EMITS TOXIC FUMES UNDER FIRE CONDITICNS.

SECTION 6. - - - - - - ACCIDENTAL RELEASE MEASURES - - - - - EVACUATE AREA.

WEAR SELF-CONTAINED EREATHZNG AZEARTTUS, RUEEER SOOTS FND EEATY RUBBER GLOVES.

COVER WITH DRY-IIME, SAND, OR SODA ASH. PIACE IN COVERED CONTAINERS USING NCN-SPARKING TOOIS AND TRANSPORI OUTDOCRS.

VENTIIATE AREA AND WASH SPILL SITE AETER MATERIAL PICKUP IS COMPIETE.

SECTION 7. - - - - - - KANDIING END STCRAGE- $\ldots+\ldots$ REEER TO SECTION 8.

SECTION 8. - - - - - EXPOSURE CONTROIS/PERSONRI PROTECTION- - - - CHEMICAL SAFETY GOGGIES.

SAEETY SHOWER AND EYE BATH.

BACESHIELD (8-INCH MINIVUM).

NIOSH/MSHA-ARPROVED RESEIRATOR IN NONVENTILATED AREAS AND/OR FOR

EXPOSURE ABOVE THE RCGIH TIV.

MECHANICAI EXHAUST REQUIRED.

RLBBER GLOVES.

AVOID BREATHING VAPOR.

DO NOT GET IN EYES, ON SKIN, ON CIOTEING.

RVOID PROLONGED OR REPEATED EXPOSURE.

WASH THOROUGHLY AFTER HANDLIISG.

CORROSIVE.

EOISON

KEEP TIGHTLY CLOSED.

MAY DEVELOP PRESSURE.

REACTS VIOLENTLY WITH WATER.

STORE IN A COOL DRY PLACE.

SECTION 9. - - - - - . PHYSICAI AND CHEMICAI PRORERTIES - - - - - -

APQEARANCE AND ODOR

COLORLESS LIOUID

PHYSICAI PRCPERTIES

RIASHEOINT

VAFOR PRESSURE:

SPECIFIC GRAVITY:

VAPOR DENSITY:

NONE

1.3

SECTION 10. - - - - - - STABIIITY AND REACTIVITY - - - - - -

INCOMPATIBILITIES

BASES

RYINES

AZKAII METALS

COPPER, COPPER ALLOYS

AZUMINUM

CORRODES STEEI

SO NOT ALLOW WATER TO ENTER CONTAINER BECAUSE OE VIOLENT REACTION.

HAZARDOUS COMBUSTION OR DECOMPOSITION PRODUCTS

TOXIC FUMES OE:

HYDROGEN CHLORIDE GAS

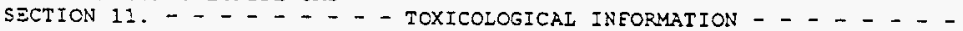
ACUTE EFEECTS

MAY BE EATAL IE INHALED, SWALLOWED, OR ABSORBED THROUGH SXIN. CAUSES BURNS.

Page 2 
HNF-SD-RE-TPI-003, Rev. 0

PRODUCT \#: 26759 NAME: HYDROCHLORIC ACID REAGENT

MATERIAL SAFETY DATA SHEET, Valid 2/96 - 4/96

Erinted Thursday, February 01, 1996 10:50AM

MATERIAL IS EXTREMELY DESTRUCTIVE TO TISSUE OF THE MUCOUS MEMERANES

AND UEPER RESPIRATORY TRACT, EYES AND SKIN.

INHALATION MAY EE FATAL AS A RESUIT OE SPASM, INELAMMATION AND EDEMA

OE THE LARYNX AND BRONCHI, CHEMICAI PNEUMONITIS AND FULMCNARY EDEMA. SYMETCMS OE EXPOSURE MAY INCLUDE BURHING SENSATION, COUGHING,

WUEEZZNG, GARYNGITIS, SHORTNESS OE EREATH, HEADACHE, NAUSEA ALD

VOMITING.

RTECS \#: MW4025000

HYDROCHLORIC ACID

IRRITATION DATA

EYE-RET 5 MG/3OS RINSE MID

TOX ECITY DATA

IHI-HNN ZCLO:1300 FEM/3OM

IHI-HWIN ICLO:3000 P PM/SM

LNR-MA.S IDLO: $81 \mathrm{MG} / \mathrm{KG}$

IHI-RA.T IC50:3124 PPM/1H

IHL-MLS ICS0:1108 P PM/IH

IFR-MLIS ID50:1449 MG/KG

CRI-RET IDSO:900 MG/KG

\section{MSDS 036338}

TARGET ORGAN DATA

SENSE ORGANS AND SZECIAI SENSES (OTHER EYE EFFECTS)

IUNGS, THORAX CR RESPIRATION (RESPIRATORY STIMUIATION)

SKIN AND APPENDAGES (AETER SYSTEMIC EXPOSURE: DERMATITIS, CTLER)

ONLY SEIECTED REGISTRY OF TCXIC EFEECTS OE CHEMICAL SUBSTANCES

(ETECS) DATA IS PRESENTED HERE. SEE ACTUAL ENTRY IN RTECS FCR COMPLETE INFORMATION.

SECTION 12 . - - - + - - ECOLOGICAL INEORMATION - DATA MOT YET AVAINABZE.

SECTION 13. - - - - - - - DISPOSAI CONSIDERATIONS - - - - - - FOR SMALL QUANTITIES: CAUTIOUSLY ADD TO A LARGE STIRRED EXCESS OF WATER. ADJUST THE PH TO NEUTRAL, SERARATE ANY INSOLUBLE SOLIDS OR LIQUICS AND PACKAGE THEM FOR HAZARDOUS-WASTE DISPOSAL. ELUSH THE AQUEOUS SOLUTION DOWN THE DRAIN WITH PIENTY OE WATER. THE HYDROIYSIS AND NEUTRALIZATION REACTIONS MAY GENERATE HEAT AND FUMES WHICH CAN BE CONTRCLIED BY THE RATE OE ADDITION.

OBSERVE ALL FEDERAL, STATE AND LOCAL ENVIRONMENTAI REGULATIONS.

SECTION 14. - - - - - - - - TRANSPORT INEORMATION - - - - - - CONTACT SIGMA CHEMICAL COMRANY FOR TRANSPORTATION INEORMATION.

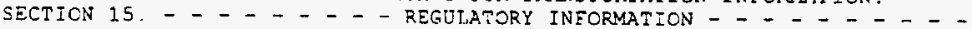
EUROPEAN INEORMATION

EC INLEX NO: $\quad 0: 7-002-00-2$

CORROSIVE

R 34

CAUSES BUENS.

$R \pm 4$

REACTS VIOLENTLY WITH WATER.

S 26

IN CASE OF CONTACT WITH EYES, RINSE IMIDIATELY WITH ELENTY OF WAFER AND SEEK MEDICAI ADVICE.

$5 \quad 27$

TAKE OFE IMMEDIATELY ALI CONTAMINATES CLOTHING.

S $36 / 37 / 39$

WEAR SUITABLE RROTECTIVE CLOTHING, GLOVES AND EYE/EACE

RROTECIION. 
HNF-SD-RE-TPI-003, Rev. 0

REVIENS, STANDARDS, AND REGUIAIIONS

$O E I=M A K$

ACGIH TLV-CL 5 PFM

B5INAB $6,773,91$

IARC CANCER REVIEN: HUMAN INAJECUAFE EVIDENCE IMEMDT $54,189,92$

IARC CANCER REVIEW:ANIMAI INADEQUATE EVIDENCE IMEMDT 54, 189,92

IARC CANCER REVIEW: GROU? 3

IMEMDT $54,189,92$

ERA FIERA 1988 PESTICIDE SUBJECT TO REGISTRATICN OR RE-REGISTRATION EEREAC $54,7740,89$

MSHA STANDARD:AIR-CI 5 PPM (7 MG/MI) DTIV $=3,129,71$

OSHA EEL (GEN INDU):CL 5 EEM (7 MG/M3)

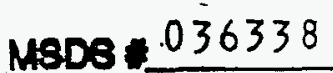

CERGER 29, $-910.1000,94$

OSHA EEI (CONSTRUC):CL 5 PPM (7 MG/M3)

CERGER 29,1926.55,94

OSHA EEL (SHIPYARD):CL 5 PPM (7 MG/M3)

CERGER 29,1915.1000,93

OSHA EEL (EED CONT):CI 5 EPM (7 MG/M3)

CERGER 41,50-204.50,94

OEL-ALSTRAIIA:TWA 5 PQM (7 MG/M3) JAN93

OEL-ALSTRIA: IWA 5 PPM (7 MG/M3) JANG3

OEL-BELGIUM:STEL 5 PFM (7.7 MG/M3) JA.N93

OEL-DENMARK:STEL 5 PFM (7 MG/M3) JAR93

OEL-FINLAND: STEL 5 PFM (7 ME/M3);SKIN JAN93

OEL-FRANCE:STEL 5 PPM (7.5 MG/M3) JAN93

CEL-GERMANY: TWA 5 PPM (7 MG/M3) JAN93

OEL-HUNGARY : STEL 5 MG/:13 JAN93

CEL-JAPAN: SIEL 5 PEM $(7.5 \mathrm{MG} / \mathrm{M} 3)$ JAN93

CEL-THE NETHERLANDS:TWA 5 PPM (7 MG/M3) JAN93

CEL-THE EHILIPEINES:TWA 5 PRM (7 MG/M3) JAN93

OEE-PGLAND:TWA 5 MG/M'3 JAN93

OEL-RLSSIA:STEL 5 PPM (5 MG/M3) JAN93

CEL-SWEDEN:STEL 5 PEM (3 MG/M3) JAN93

CEL-SWITZERIAND:TWA 5 PFM (7.S MG/M3); STEL 10 PPM (15 MG/M3) JAN93

CEL-THAILAND:TWA 5 PFM $(7$ MG/M3) JAN93

OEL-TURKEY:TWA 5 PPM (7 MG/M3) JAN93

OEL-UNITED KINGDOM: TWA 5 PHM (7 MG/M3):STEL 5 PEM (7 MG/M3) JAN93

OEL IN BULGARIA, COLOMBIA, JORDAN, KOREA CHECK ACGIH TLV

OEL IN NEN ZEALAND, SINGAFORE, VIETNAM CHECK ACGIH TLV

NIOSH REL TO HYDROGEN CHLORIDE-AIR:LL 5 PPM

NIOSH* DHHS \#92-100,92

NOHS 1974: HZD 38580; NIS 360; TNE 87434; NOS 156; TNE 824985

NOSS 1983: HZD 385BO; NIS 321; TNE EO309; NOS 183; TNE 1238572 ; TEE

388130

EPA GENETOX PROGRAM 1988, NEGATIVE: CELI TRANSFORM. -SA7/SHE

EPA TSCA SECTION 8 (B) CHEMICAI INVENTORY

EPA TSCA SECTION G(D) UNPUBIISHED HEALTH/SAEETY STUDIES

EPA TSCA SECTION 9(E) RISK NOTIEZCATION, 8EHQ-0892-9246

ON ERA IRIS DATABASE

EPA TSCA TEST SUEMISSION (TSCATS) DATA BASE, OCTCBER 1995

NIOSH ANAIYTICAL METHOD, 1994: ACIDS, INORGANIC, 7903

J.S. INEORMATION

THIS PRODUCT IS SUBEECT TO SARA SECTION 313 REPORTING REQUIREMENTS. 
HNF-SD-RE-TPI-003, Rev. 0

$r-29 / 96 \quad 88: 513: 86$

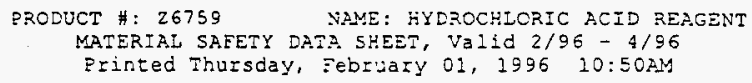

MSDS $\quad 036338$ 
HNF-SD-RE-TPI-003, Rev. 0

MAY 13 '96 11:43AM UOP MT LALRR NT

P. $2 / 6$

UOP

Material Safety Data Sheet

1. EXPERIMENTAL PRODUCT AND COMPANY IDENTIFICATION

Page 1 of 5

PRCDUCT: UORn IONSIVM Ion Exchanger Type IE-911

Januery 1985

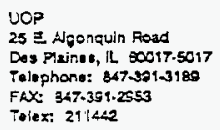

2. COMPOSITION

\section{MATERIAL}

silicion dloxde

Thanium dicsJde

Sodium oxida

Trade Secrot material

Trade Secrei metal oxice

Auminum osjo

(non-fibrous)

Copper oxide

Calcium oxicle

Chromium oxide

Magnesium oxde

\section{CAS No.}

$7631-86-3$

$13463-67-7$

$1313-59-3$

Trade Secret

Trade Secrat

$134428-1$

$1317-28-0$

$1305.78-8$

$1308-38.3$

$1309-48-4$
Emergency Aoglatanee

24 tiour Entrency Tolephene Numbers:

USA:

Canad:

Origico USA:

\section{UOP}

847/301-2123

Chemieo $800 / 424-83 \infty$

Canition $813 / 985-5585$

Chemune 202/48376:s 
POTENTIAL HEALTH EFFECTS:

F rimary Routes of Exposure: Contact with skin and eyes. Exposure mey also occur via inhalation or ingestlon it product dust is generated during handling. Product ingestion is unlikely but may oceur it proper saiety/trysiene procedures ara not followed.

Skin Contat:

The solid or dust may cause irritation with repeated or prolonged exposure.

Eye Contact:

Solid or dust may cause iritation or reddening due to mechanical acticn. Mid to moderate ipritation of eye membrane may also occur possibly resurting in swelling.

Inhalation:

May cause irritation of the nose and ihroat, acompanied by cough and chest discomfor. Prolonged inhalation may cause lung damage.

Ingestion: This product is considered to have a low crofer of texictry.

Carcinogenicity Classification:

IARC: Titanium dicxide and Silicon dicxici - Not dassifiable as human carcinogens (Group 3). None of the other components are ciassified.

NTP: None of the product components are classified.

OSHA: None of the product components are classitied.

\section{FIRST AID MEASURES}

\section{MSDS \# 053329}

Skin: Wash affected area whin soap and water. If irritation occuis, obtain medical attention.

Eyes: $\quad$ Flush with water for at least 15 minutes. If isritation persists, cbtain medcal attention.

inhalation: Femove affected perscn to iresh alr. If breathing is difficult, oxygen may be needed; obtain medical attention.

Ingestion: Do net Induce vomiting. Victim shouid drink large quantities of milk, gelatin solutlon or water. Obtain medical attertion.

\section{FIRE FIGHTING MEASURES}

Fash Point:

Method:

Exingulshing Media:

Fire and Explosion Hazard:
Nor applicable

Not applkable

Material does nor bum. Use media appropriate for surrounding fire (carbon dioxide, dity chemical or fcam).

Used materal may contain products of a hazardous nature. The user of this product must identify the hazards of the retalned meterial and inform the fire igiters of these nazards.

\section{ACCICENTAL RELEASE MEASURES}

Isolate the affected area; restrict entry to the affected area to personnel wearing proper perscnal protectwe equipment. Speclal attention should be glven to respiratory and eye protection, because recovery of material can be expected to generate dust Vacuum or shevel up spilled raterial, placing it into appropriate recovery drums or containers.

\section{HANDLING AND STORAGE}

Store in tlghtly closed, property labeled containers. Do not take intemaly. Avold repeated or prolenged contact wth skin. Avoid comact with eyes and intralation of dust. 


$$
\text { P. } 4 / 5
$$

\section{EXPOSURE CONTROLS AND PERSONAL PROTECTION}

Respiratory: Where natural ventiation is inadequate, use mechanical ventilation, other engineering controls or a texic dust respirator (in USA NICSH/MSHA-approved) to prevent inhalation of dust

Skln:

Chemical-resistant gloves and work uniform as necessary to prevent repeated or prolonged skin contact.

Eye: Sefety glasses or goggles as necessary :o prevent eye contact.

\section{PHYSICAL AND CHEMICAL PROPERTIES}

Thos data do not represant tachnicel or salas spselfiejiens.

Boiling Point:

Bulk Density:

Vapor Pressidre:

Vapor Coistive:

Pour Point:

Frenzing Point:

Specifie Gravity
Net appicabla

Not avalable

Not applicabla

Not applicable

Net appilcable

Not applicable

Not applicable

\section{MSDS* 053329}

Solubitity in Water: -

\% Volatile:

Appearance:

Cdor:

ph in 10\% squeous shrry:

Physical State: insoluble...t-

Not applicable

White Crystalline Powder

Odortess

apprexinetely 11

Solid

\section{STAEILITY AND REACTIVITY}

Stabiny:

Condritons to Avoid:

Hazardous Decemposition Products:

Hazardous Polymerization:

incompatible Materials:
Stabie.

None knowe

None.

Wil not oceur.

Avoid centiet with acid and easily oxldized materials.

\section{TOXICOLOGICAL INFORMATION}

No data aveileble for this product, the following data is for a similar product:

Oral LDS0

Eyo Irritaton

Skin Irritation

Skin Sensitization

Cyrotoxieity

\section{ECOLOGIC INFORMATION}

No data currendy available.

$$
>5 \mathrm{~g} / \mathrm{kg} \text { (rat) }
$$

The product is no more than moderately intating to the eyes of rabbits. No corneal damage was seon, Iritis was seen in 2/6 animals atter 1 hour, but none was seen after 48 hours. All $B$ rabbits showed irritation of the conjunctiva after 1 hour, but after 72 hours only i still showed the irritation.

The product is no more than slighty irrtating to the skin of rabbits; only barely perceptible erythema was noted at the 1 -hr score time in 2/6 rabblts, score of 1 for 2/6 rabbits (maximum possible score is a).

The product was found not to producs skin sensitizaton in quinea pigs.

The product is clessified in the nond etectable category according the IERL cyotoxicity scheme (Sanchu. 1979). The product was considered to be noncytotoxic to rabbit alveclar macrophage ceils at concantrattons less than or equal to $1000 \mathrm{\mu g} / \mathrm{ml}$. 


$$
\text { P. } 5 / \mathrm{S}
$$

IONSN IE-911

Page 4 of 5 January 1996

\section{DISPOSAL CONSIDERATIONS}

Dispose of froduct in acocrdence with al applicable government regulations. The unused product and its components are not listed by generic name or trademark name in the U.S. EPA's Resource Conserration and fecovery ACt (RCRA) Hazardous Waste Manacement Regulatlons and do not possess any of the four identitying characteristles of hazardous waste.

\section{TRANISPORTATION INFORMATION}

DOT Hezand Classification:

iD Number:

IMO Hazard Elasstilcatlon:

ID Number:
Not Regulared

Not Applicable

Not Regulated

Not Appilleable

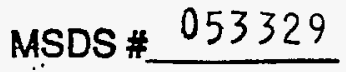

.

\section{REGULATORY INFORMATION}

U.S. TOXIC SUBSTANCES CONTROLACT $T S C A)$ : All the ingreciants of this product ara registered in accordance with ISCA

U.S. SUPEAFUND AMENDMENTS AND REAUTHCFIZATION ACT (SARAL TIILE III, SECTION 3\%3: The fOllOwing component(s) in this product is subject to the ieporing requirements of sectlon 313 of the Emergency flanning and Community flight-To-Know Act, 40 CFR 372: -none-

EUROPEANINYENTORY OFEXISTING COMMERCIAL CHEMICAL SUBSTANCES (EINECS): Ths components of this reparation ase included on the EINECS.

$\begin{array}{ll}\text { Silicon doxdde } & 2315454 \\ \text { Titanium dicxide } & 2356755 \\ \text { Sodium cxide } & 2152089 \\ \text { Trade Secret Waterial } & \text { listed } \\ \text { Trade Secret Material } & \text { listed } \\ \text { Numinum oxide } & 2156915 \\ \text { Copper oxide } & 2152691 \\ \text { Calcium exide } & 2151389 \\ \text { Chromium axide } & .2151509 \\ \text { Magneslum cxide } & 2951719\end{array}$


16. OTHER INFORMATION

For additional information concerning this product contact the following:

For health, safety \& onvironmental

informatlon, please contact:

Product Stenardshlp Manager

Headh, Safety and Environmental Depatment UOP

25 E. Algonquin Fd.

Ces Plaines, IL 50017-5017

Tolephone: (247) 3913189

Fax: $(847) 391-2953$
For technical or product purretrasing information, please contact:

Accoum Manager

UOP

307 Fellowship Read

Sulte 207

Mt Laurel, New Jersey 08054

Telephone: (\$OS) 727.9400

. Fax: (609) 727-9545

\section{PRODUCT EMERGENCIES}

If you have a product-related energency, resuhing in an incident such as a spal or releass of product, human exposure, etc. and need assistance from UOP, please call us at the following number:

\section{HOUR EMERGENCY Telephone Number: (847) 391-2123}

The data and recommendations presented in this data sheet conceming the use of our product and the materlals contained therein are believed to be accurate and are based on information which is considered rellable as cf the date hereot. However, the cusioner should determine the sultability of such materials for his purpose before adopting inem on a commercial scale. Sinca the usa of our products by others is beyond our $\infty$ ntrol. no guarantee, express or implled, is rade and no responsledity assumed for the use of this material or the results to be obtained thereftom. Irformation on this form is hirnished for the purpose of compliance with Government Health and Safety Fegulations and shall nct be used for any cther purposes. Moreover, the recommendations contained in this deta steet are not to be construed as a license to operate under, or a secommendation to infringe, any existing patents, nor should they be confused with state, municipal or insurance requitements, or with national safery codes.

UOP

Date: January 1996

Ravision: 1

Supersedes: February 1995 
HNF-SD-RE-TPI-003, Rev. 0

THIS PAGE INTENTIONALLY LEFT BLANK 
HNF-SD-RE-TPI-003, Rev. 0

Appendix C: Valving Configuration Figures

C-i 
HNF-SD-RE-TPI-003, Rev. 0

THIS PAGE INTENTIONALLY LEFT BLANK

C-ii 


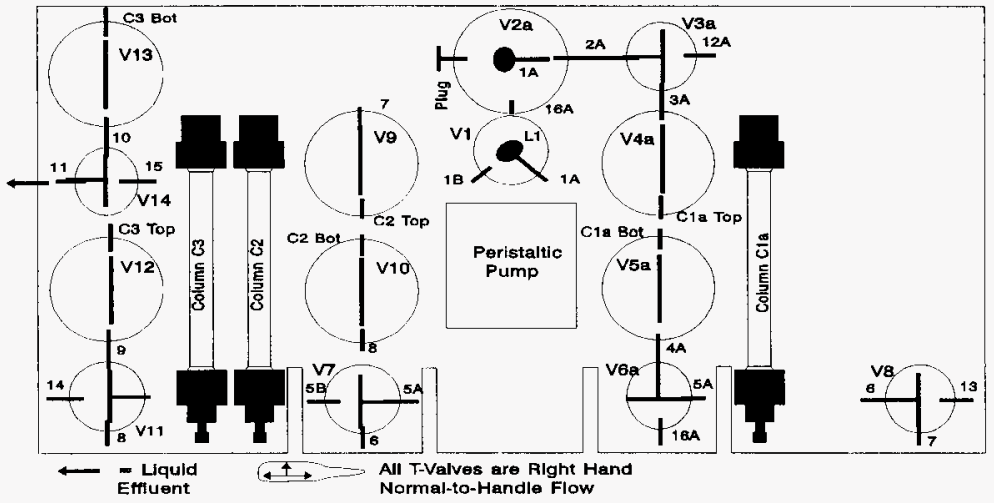

Fijgure C-1: Config. 1A, Primary Column (C1a) Full System Feed Valving

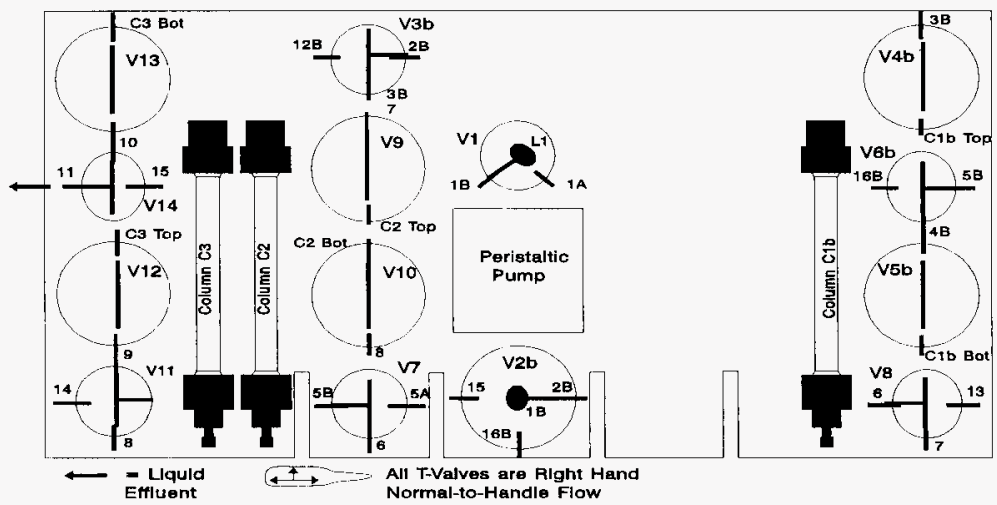

Figure C-2: Config. 1B, Backup Column (C1b) Full System Feed Valving 


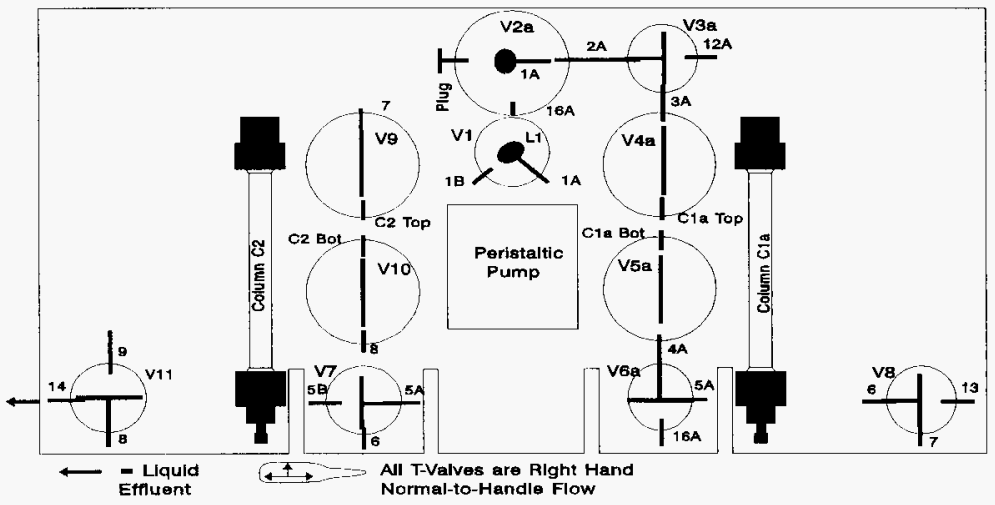

Figure C-3: Config. 2A, Forward Feed through Primary and First Guard Columns

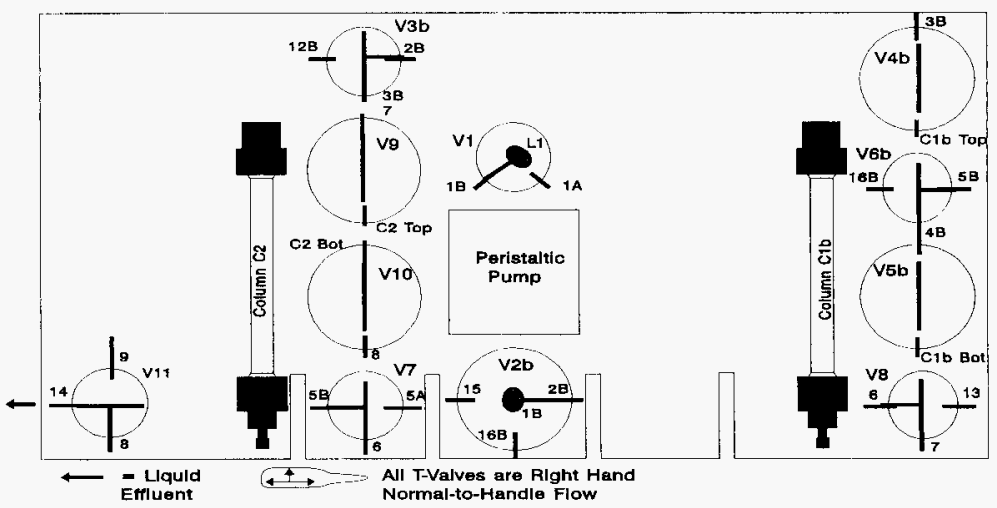

Figure C-4: Config. 2B, Forward Flow Through Backup and First Guard Columns 


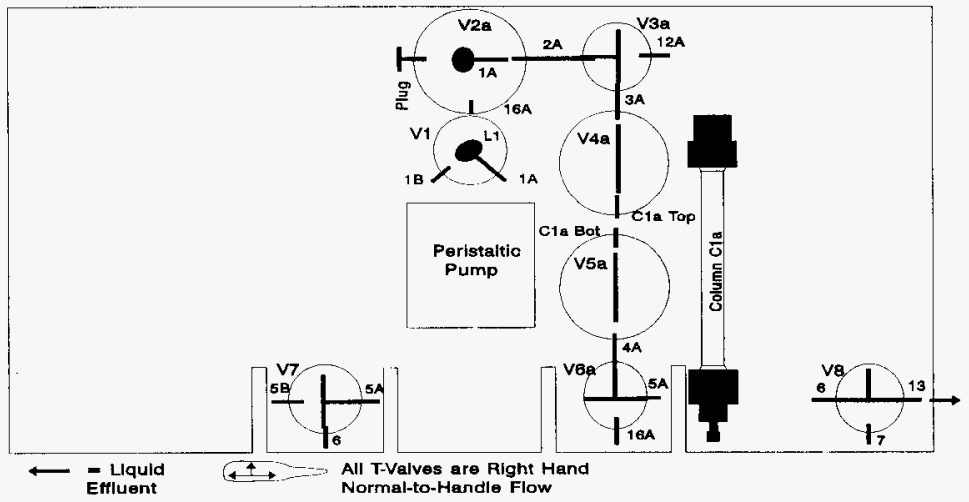

Figure C-5: Config. 3A, Forward Flow Through Primary (Cla) Column to Sample

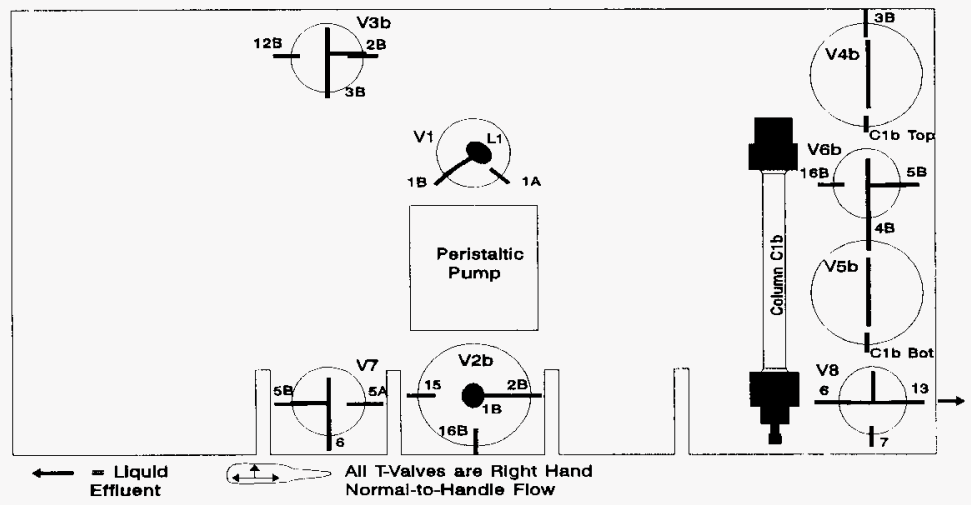

Figure C-6: Config. 3B, Forward Flow Through Backup (C1b) Column to Sample 


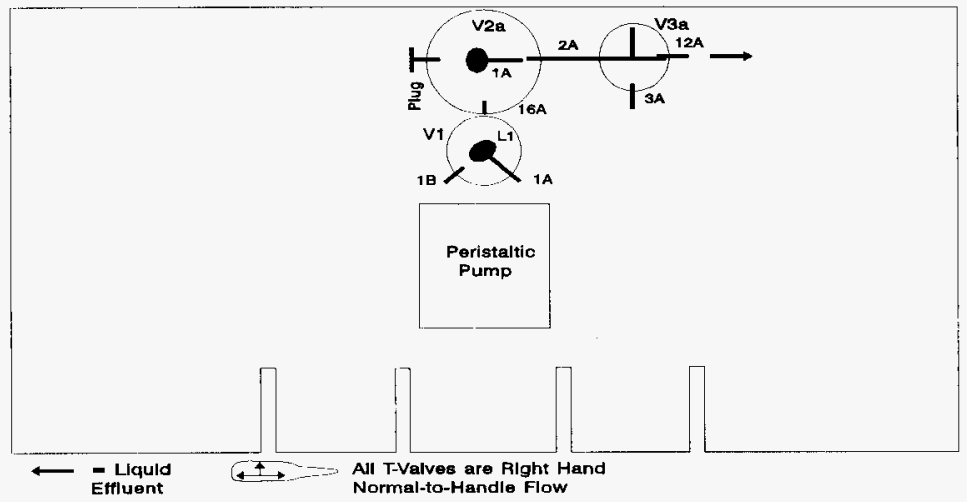

Figure C-7: Config. 4A, Forward Flush Bypass to Line 12A

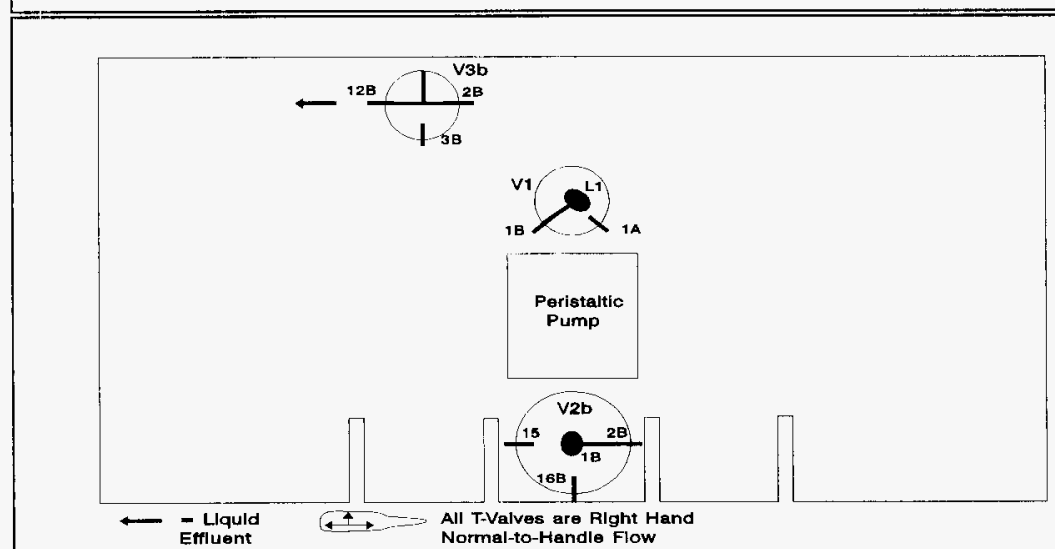

Figure C-8: Config. 4B, Forward Flush Bypass to Line 12B 


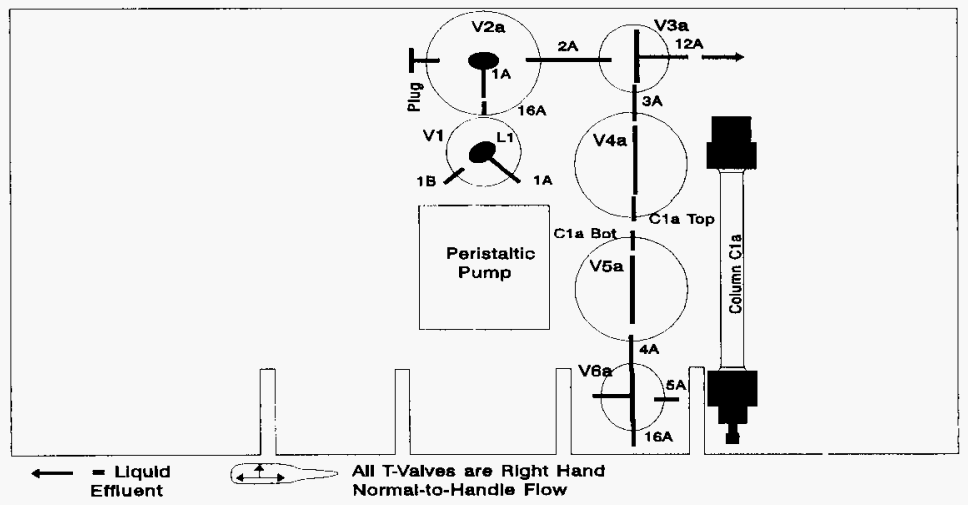

Figure C-9: Config. 5A, Reverse Flush Through Primary (C1a) Column

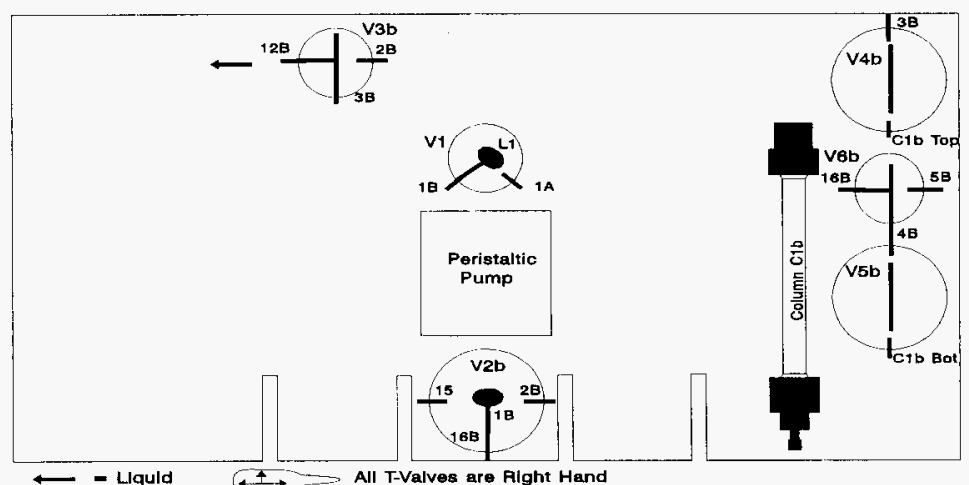

Figure C-10: Config. 5B, Reverse Flush Through Backup (C1b) Column 
HNF-SD-RE-TPI-003, Rev. 0

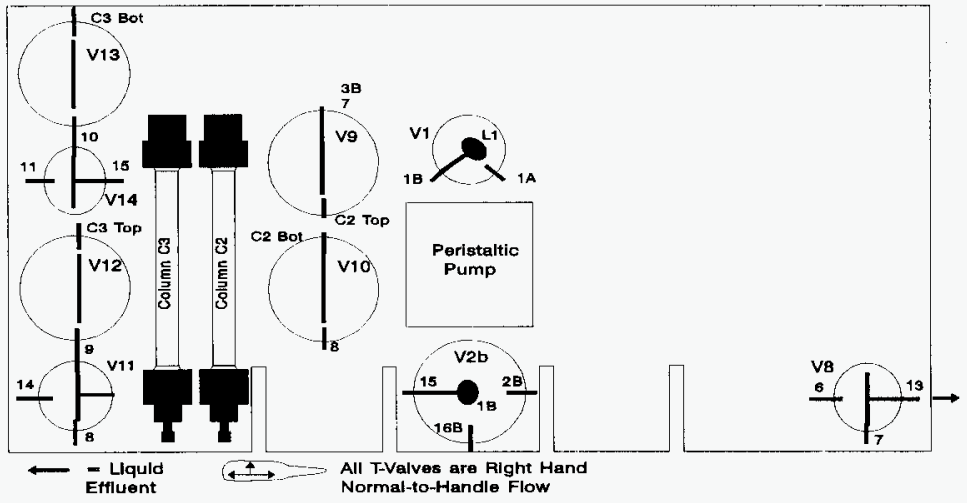

Figure C-11: Config. 6, Reverse Flush Through Guard Columns (C3 and C2) 
HNF-SD-RE-TPI-003, Rev. 0

Appendix D: Gamma Probe Operation

D-i 
HNF-SD-RE-TPI-003, Rev. 0

THIS PAGE INTENTIONALLY LEFT BLANK

D-ii 


\section{GENERAL INSTRUCTIONS BETA/GAMMA HOT CELL PROBE VERSION 1.0}

\section{INTRODUCTION}

This desk instruction provides checklist-style guidance on producing data with the bela/gamma hot cell probe. This instruction assumes the person has read the GammaVision $^{\mathrm{TM}}$ software manual, and understands the basics of Microsoft Windows ${ }^{1}$ operating system as well as nuclear spectroscopy.

\section{Setup:}

Cable connections:

Ensure that all power cables are connected.

Ensure that cables to the probe are connected.

\section{Powering up:}

Ensure that both bias power supplies are switched to OFF and set to 0 volts (V). Reset the beta detector bias supply if necessary.

Turn on the main power switch at the bottom of the relay rack.

Turn on the bottom NIM bin.

Turn on the computer (the bottom NIM bin power MUST be on).

Turn on the top NIM bin.

Turn on the gamma detector bias supply (top NIM bin). Slowly raise the voltage up to $800 \mathrm{~V}$ Positive.

Plug the beta amplifier (Top NIM crate, Canberra Fast ${ }^{2}$ spectroscopy amp) output to an oscilloscope.

\footnotetext{
${ }^{1}$ Trademark of Microsoft Corporation, Redmond, Washington.

${ }^{2}$ Trademark of Canberra Industries, Inc., Meridian, Connecticut.
} 
Place a source under the beta detector. This may be needed to provide enough counts to see in the oscilloscope.

Turn on the beta detector bias supply (bottom NIM crate). Very slowly $(<20$ volts $/ \mathrm{sec})$ raise the beta detector bias voltage to $800 \mathrm{~V}$, waiting until the pulse on the oscilloscope returns to normal before proceeding.

When the beta detector bias voltage is at $800 \mathrm{~V}$, reconnect the amplifier output to the $\mathrm{T}$-connector at channel 2 of the single-channel analyzer (SCA).

Turn the pointer on (up). The switch is in a blank NIM module in the top NIM bin.

\section{Starting GammaVision $^{\mathrm{TM}}$}

At the C: prompt, enter "win" to enter Windows ${ }^{\mathrm{TM}}$.

Double-click on the GammaVision ${ }^{\mathrm{TM}}$ icon.

Switch to multichannel buffer (MCB) \#1 (gamma) if not already there.

Run job "gatelcn.job".

Switch to MCB \#5 (beta).

Run Job "gate5off.job"

\section{Spectrometry:}

Taking a spectrum in GammaVision ${ }^{\mathrm{TM}}$ is as easy as hitting ALT2 (STOP), ALT3 (CLEAR), ALT1 (START), and giving the program all the information it requests. GammaVision $^{\mathrm{TM}}$ is set up to ask for collection live time and sample description.

Spectra for most samples will be taken using an automated .JOB file, which only requires the user to input live time and sample description.

\section{Running the counters:}

When you are ready to start a count, hit the stop button (or switch) on the timer, then hit the resiet (to clear previous counts), and then hit the start button (switch) to start the count. 


\title{
Daily Energy Calibration and QA Check
}

\author{
Perform startup.
}

Center the ${ }^{154} \mathrm{Eu}$ quality assurance (QA) source under the probe (at the intersection of the light beams of the pointer).

Set the live time on the MCBs and counters to 2,000 seconds.

Start the counters and the MCBs.

ON MCB \#1, Recall qaeusrc.roi.

Compare the peak centroids to the published values for ${ }^{154} \mathrm{Eu}$.

If the centroids of the peaks are shifted from the published values by more than $10 \mathrm{keV}$, adjust the amplifier fine gain to match the centroids with published values.

Stop and start the MCBs between adjustments of the fine gain controls.

If the actual values are more than $30 \mathrm{keV}$ apart, consult with the scientist on whether a recalibration is necessary.

Compare the endpoint of the beta spectrum taken to the file $\mathrm{C}:$ IbetaprolSrtdQA1.chn. If the endpoint is different, adjust the fine gain on the Canberra amplifier.

After completing the calibration and QA check, take a spectrum with both MCBs.

Run .JOB file C:ImcafilelQAcheck.job.

At the end of the count record all counter values.

Compare the current QA check source values to previous QA counts; the values should be within $20 \%$. The values below are from page 10 (repeated on page 37 ) of laboratory notebook WHC-N-11151 1 (Beck 1994), and the spectra files: Gamma, C\datalgamprołsrtdQA.chn; Beta, C:\datalbetaprolsrtdQA1.chn.

$\begin{array}{lll}\text { Tctal Beta (TB): } & 2,073,772 & \text { Betas Above Gammas (BAG): } 377 \\ \text { Tctal Gamma (TG): } & 1,448,951 & \text { Gammas Above Cesium (GAC): } 21\end{array}$

Cesium-137 (Cs): $\quad 72,892$
Eu-154@248 keV 385,290 counts,
@723 keV
85,423 counts@993 keV10,671 counts
@1274 keV 5,667 counts 


\section{Running Samples:}

If the daily QA check is OK, then samples may be run.

Run the .JOB file gammaV5,job .

Remember which scan you're on.

Scans 1 and 7 are backgrounds, so the sample must be moved away from the probe during those scans.

Label the scans appropriately at $0.5,5,9.5,14$, and 18 inches from the bottom of the core segment.

Align the sample with the laser beam crosshairs so as to position the sample for scans 2 through 6 .

Return the sample to 11A Hot Cell Operations personnel.

After the end of the run (including backgrounds), start Quattro Pro ${ }^{\mathrm{TM}}$.

Open the file appropriate to the geometry of the sample. LogSS5. WQ1 should be used for "log" samples, and TraySS\#3.WQ1 for "tray" (flat) samples.

Hit Alt A.

Change the text on the 2nd line of the graph to reflect the identity and nature of the sample.

Print-to-Fit and Print Graph. There is no need to change any settings before printing, as everything is already set up.

Save the Quattro Pro ${ }^{\mathrm{TM}}$ file in a directory appropriately named for the sample.

In Windows ${ }^{\mathrm{TM}}$ File Manager, copy all the files in the directory

$$
\text { C: } \text { practjob }
$$

to a directory that is labeled in such a way as to identify the sample.

Paste all the output into the laboratory notebook.

You're done!... 


\section{Normal Shutdown:}

Shut the pointer off.

Normally, everything else is left on.

\section{Total Shutdown:}

Perform the normal shutdown.

Exit Windows ${ }^{\mathrm{TM}}$.

Shut off the computer.

Slowly turn the bias supply voltages down to 0 and lock them there.

Turn off the bias supplies.

Turn off the NIM bins.

Turn off the fans (back of rack).

\section{REFERENCES}

Beck, M. A., 1994, Controlled Laboratory Notebook, Hot Cell Beta/Gamma Probe, WHC-N-120 7, Westinghouse Hanford Company, Richland, Washington.

Beck, M. A. et al. WHC-SD-WM-DTR-039 is the source of this instruction set. 


\section{DISTRIBUTION SHEET}

\begin{tabular}{|c|c|c|c|c|c|}
\hline \multirow{2}{*}{$\begin{array}{l}\text { To } \\
\text { Distribution }\end{array}$} & \multirow{2}{*}{\multicolumn{3}{|c|}{$\begin{array}{l}\text { From } \\
\text { SESC/PE }\end{array}$}} & \multicolumn{2}{|l|}{ Page 1 of 1} \\
\hline & & & & \multicolumn{2}{|c|}{ Date $1 / 06 / 97$} \\
\hline \multirow{2}{*}{\multicolumn{4}{|c|}{$\begin{array}{l}\text { Project Title/Work Order } \\
\text { OSeium Flow Studies at Hanford/ SST Saltcake Cesium Removal with } \\
\text { CST }\end{array}$}} & \multicolumn{2}{|c|}{ EDT No. 605785} \\
\hline & & & & \multicolumn{2}{|l|}{ ECN No. } \\
\hline Name & MSIN & $\begin{array}{l}\text { Text } \\
\text { With All } \\
\text { Attach. }\end{array}$ & Text Only & $\begin{array}{l}\text { Attach./ } \\
\text { Appendix } \\
\text { Only }\end{array}$ & $\begin{array}{c}\text { EDT/ECN } \\
\text { Only }\end{array}$ \\
\hline
\end{tabular}

Akita, R.

Appe 1, J. N.

Babad, $H$.

Beck, M. A.

Biyani, R. K. (2)

Duncan, J. B. (2)

Edmonson, D. W.

Hendrickson, D. W. (7)

Hunter, J. A.

Hyatt, J. E.

Kurath, D. E. (3)

Jewett, J. R.

Lamson, S. B.

McDonald, G. T.

Warwick, G. J.

TCRC (2)

Central Files (orig +2 )
T6-20 $X$

G3-21 $X$

S7-14

T6-09

L5-3]

L5-55

T6-09

L5-31

L5-31

S3-31

P7-20

T6-09

T6-28

L5-31

T6-12

R2-12

A3-88

$x$
$X$
$X$
$X$
$X$
$x$
$X$
$x$
$X$
$X$
$X$
$X$
$X$
$X$
$X$
$X$
$X$

